\title{
Molluscan paleontology of the lower Miocene Clallam Formation, northwestern Washington
}

By WARREN O. ADDICOTT

GEOLOGICAL S URVEY PROFESSIONAL PAPER 976

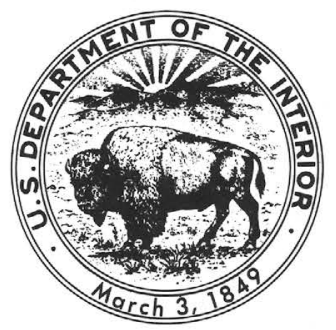

UNITED STATES GOVERNMENT PRINTING OFFICE，WASHINGTON：1976 


\title{
UNITED STATES DEPARTMENT OF THE INTERIOR
}

THOMAS S. KLEPPE, Secrelary

\section{GEOLOGICAL SURVEY}

\author{
V. E. McKelvey, Director
}

Library of Congress Cataloging in Publication Data

Addicott, Warren O.

Molluscan paleontology of the lower Miocene Clallam Formation, northwestern Washington.

(Geological Survey Professional Paper 976)

Bibliography: p. 36-39.

Includes index.

Supt. of Docs. no.: I 19.16:976

1. Mollusks, Fossil. 2. Paleontology-Miocene. 3. Paleontology-Washington (State) I. Title. II. Series: United States Geological Survey Professional Paper 976.

QE801 A2

$564^{\prime} .09797^{\prime} 9 \quad 76-608062$

For sale by the Superintendent of Documents, U.S. Government Printing Office Washington, D.C. 20402

Stock Number 024-001-02871-9 


\section{CONTENTS}

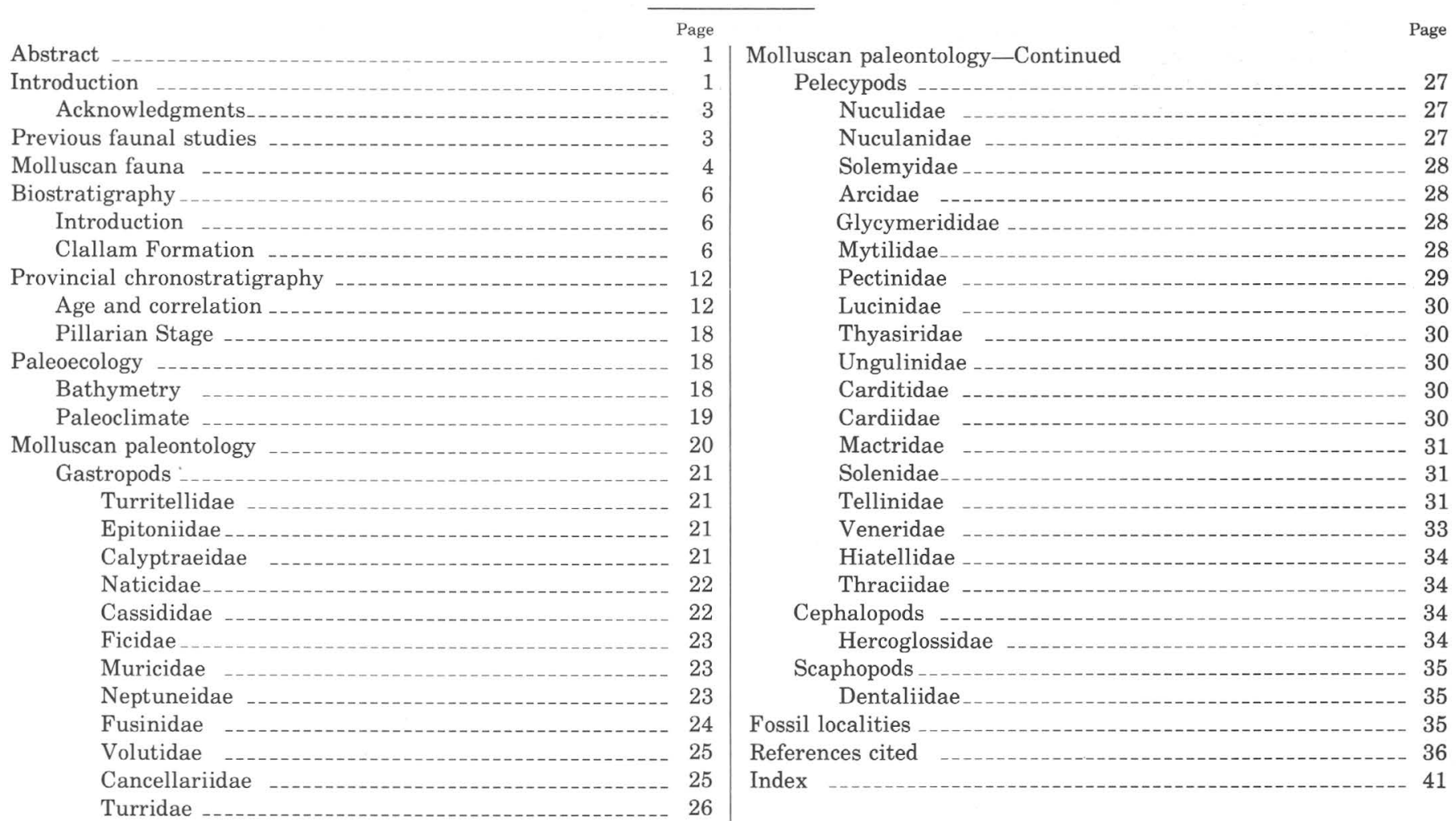

\section{ILLUSTRATIONS}

[Plates follow index]

Plate 1. Crepidula, Semicassis, Neverita, Epitonium, Trochita, Turritella, Natica, Sinum, Polinices, Ficus, Trophosycon.

2. Bruclarkia, Molopophorus, Priscofusus, Trophonopsis, Crepidula, Cancellaria, Rectiplanes, Trophosycon.

3. Acila, Nuculana, Archarax, Yoldia, Megasurcula, Ophiodermella, Xenuroturris, Ancistrolepis, Musashia.

4. Vertipecten, Solamen, Dentalium.

5. Mytilus, Glycymeris, Lucinoma, Modiolus, Anadara, Dentalium, Cyclocardia, Clinocardium, Felaniella.

6. Spisula, Macoma, Conchocele, Clinocardium, Cyclocardia, Solen.

7. Spisula, Macoma, Tellina.

8. Macoma, Katherinella, Dosinia.

9. Securella, Thracia, Panopea.

Page

1. Index map showing area of the report

2. Generalized geologic map showing distribution of the Clallam Formation and fossil localities

3-7. Photographs showing:

3. Intertidal zone exposure of Dentalium-bearing concretionary sandstone

4. Massive fossiliferous sandy siltstone at top of the upper member of the Twin River Formation

5. Intertidal zone exposure of the Clallam Formation showing intensively bioturbated sandstone _._._._._._. 9

6. Conglomerate and conglomeratic sandstone lens in the Clallam Formation

7. Intertidal zone exposure of basal concretionary sandstone of the Clallam Formation

8. Chart showing stratigraphic position of fossil localities in measured sections

9. Photograph showing chaotic blocks of sandstone in intertidal zone exposure of the Clallam Formation

10. Diagram showing correlation of the Clallam Formation with other sequences in the Pacific Northwest States and the provincial marine chronologies_-_-_-_. 


\section{TABLES}

TABLE 1. Mollusks from the Clallam Formation near Slip Point listed by Reagan (1909) with taxonomic revisions by Dall (1922) and names recognized in this report _...--

2. Mollusks from the Clallam Formation, northern Olympic Peninsula, Wash

3. Stratigraphic ranges of species from the Clallam Formation in the Pacific Coast Tertiary

4. Specifically identified mollusks from the Clallam Formation that are not known to occur in other formations

5. Mollusks characteristic of the Clallam Formation

6. Mollusks from the Clallam Formation suggestive of a provincial early Miocene age

7. New species of mollusks described here and other species believed to be new but represented by material that is inadequate for formal description 


\title{
MOLLUSCAN PALEONTOLOGY OF THE EARLY MIOGENE CLALLAM FORMATION, NORTHWESTERN WASHINGTON
}

\author{
By Warren O. Addicott
}

\section{ABSTRACT}

The Clallam Formation is a predominantly marine sandstone with minor conglomerate and siltstone exposed along the Strait of Juan de Fuca in northwestern Washington. Marine mollusks occur throughout the 600 - to 800 -m-thick formation but are especially abundant in the lowest $240 \mathrm{~m}$. New molluscan data from the Clallam provide the paleontologic base for the Pillarian Stage, a provincial timestratigraphic unit of late early Miocene age. Until this study, the Clallam had been assigned to the middle Miocene. The new lower Miocene stage, characterized by the restricted stratigraphic range of Vertipecten fucanus (Dall) and the restricted and overlapping ranges of several other mollusks, can also be recognized in coastal Oregon and southwestern Washington. Formations coeval with the Clallam, and referable to the Pillarian Stage, include the Nye Mudstone, the lower part of the Astoria Formation in the Grays Harbor and Astoria-Grays River embayments, and at least part of the Hoh rock assemblage. On the basis of molluscan data, the Clallam Formation is also correlative with the upper part of the "Vaqueros" Stage of California and, presumably, the uppermost part of the Poul Creek Formation in the Gulf of Alaska. These correlations are compatible with evidence from benthonic foraminiferal assemblages.

The molluscan fauna of the Clallam consists of 76 taxa, about evenly divided between gastropods and pelecypods. Several species are undescribed but only five new species-Semicassis pyshtensis, Priscofusus goweri, P. slipensis, Ophiodermella olympicensis, and Solamen snavelyi-are represented by material adequate for formal description. All the Clallam molluscan assemblages represent inner sublittoral depths (less than about $100 \mathrm{~m}$ ). Qualitative analysis of these assemblages indicates a gradual shallowing during deposition of the formation. The highest strata in the Clallam contain coal beds and are presumably nonmarine. This trend is the concluding phase of an Eocene to Miocene depositional cycle in which maximum depths, as determined from foraminiferal and lithologic evidence, were attained during the Oligocene.

\section{INTRODUCTION}

The Clallam Formation is a moderately thick, predominantly marine sequence of sandstone, siltstone, and conglomerate with a limited onshore distribution along the northwestern margin of the Olympic Peninsula, western Washington (fig. 1). The Clallam represents the shallow-water regressive phase of a late Eocene to Miocene depositional cycle, the greater part of which is represented by the underlying Twin River Formation. The Clallam is exposed between Clallam Bay and mouth of the Pysht River (fig. 2). Resistant sandstone and conglomerate strata within the Clallam form a bold 12-km-long segment of coast bordered on the west and the east by generally finer grained strata of the Twin River Formation.

Marine mollusks are abundant in the lowest few hundred metres of the formation, generally occurring as scattered individuals entombed in place. Molluscan assemblages also occur near the top of the formation. The Clallam may be as thick as $800 \mathrm{~m}$ (Gower, 1960).

This report is a biostratigraphic and systematic analysis of molluscan assemblages within the Clallam Formation. Biostratigraphic characterization of the Clallam Formation and evaluation of the biogeographic significance of the fauna are both dependent upon systematic analysis of the fauna.

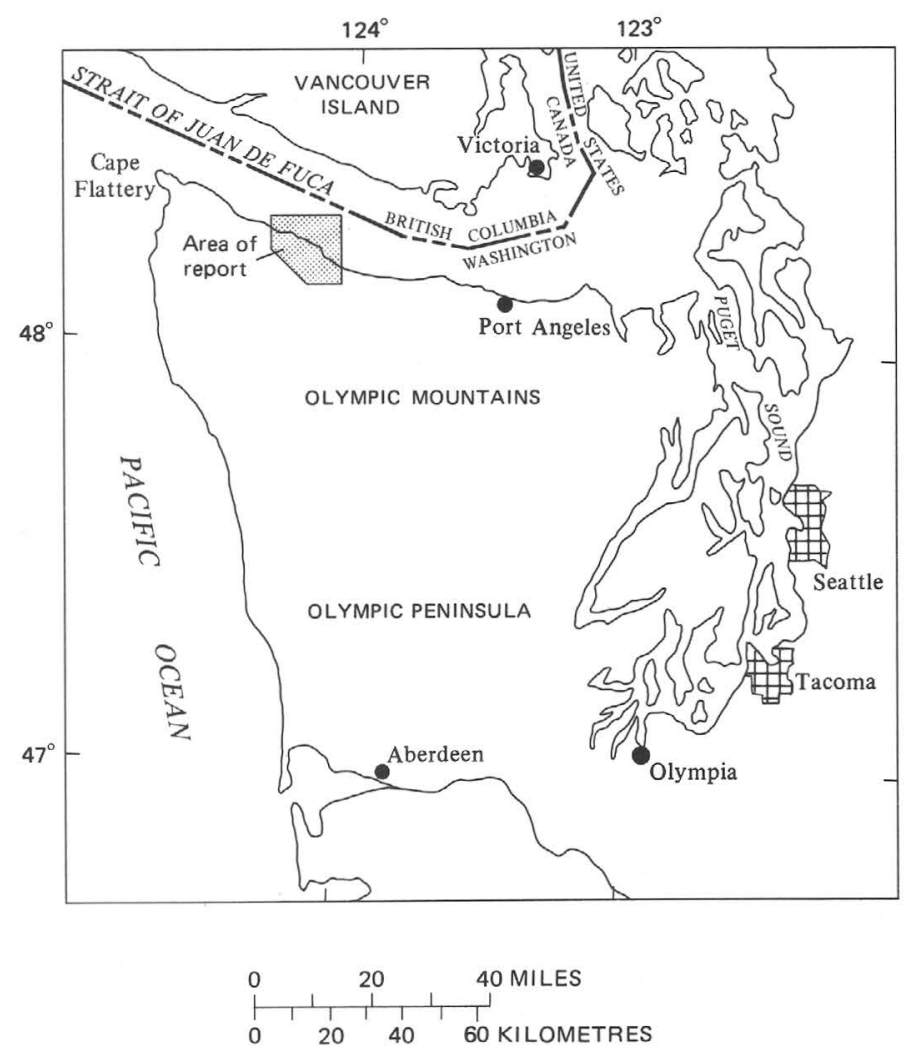

FIGURE 1.-Index map of northwestern Washington showing area of report (fig. 2). 


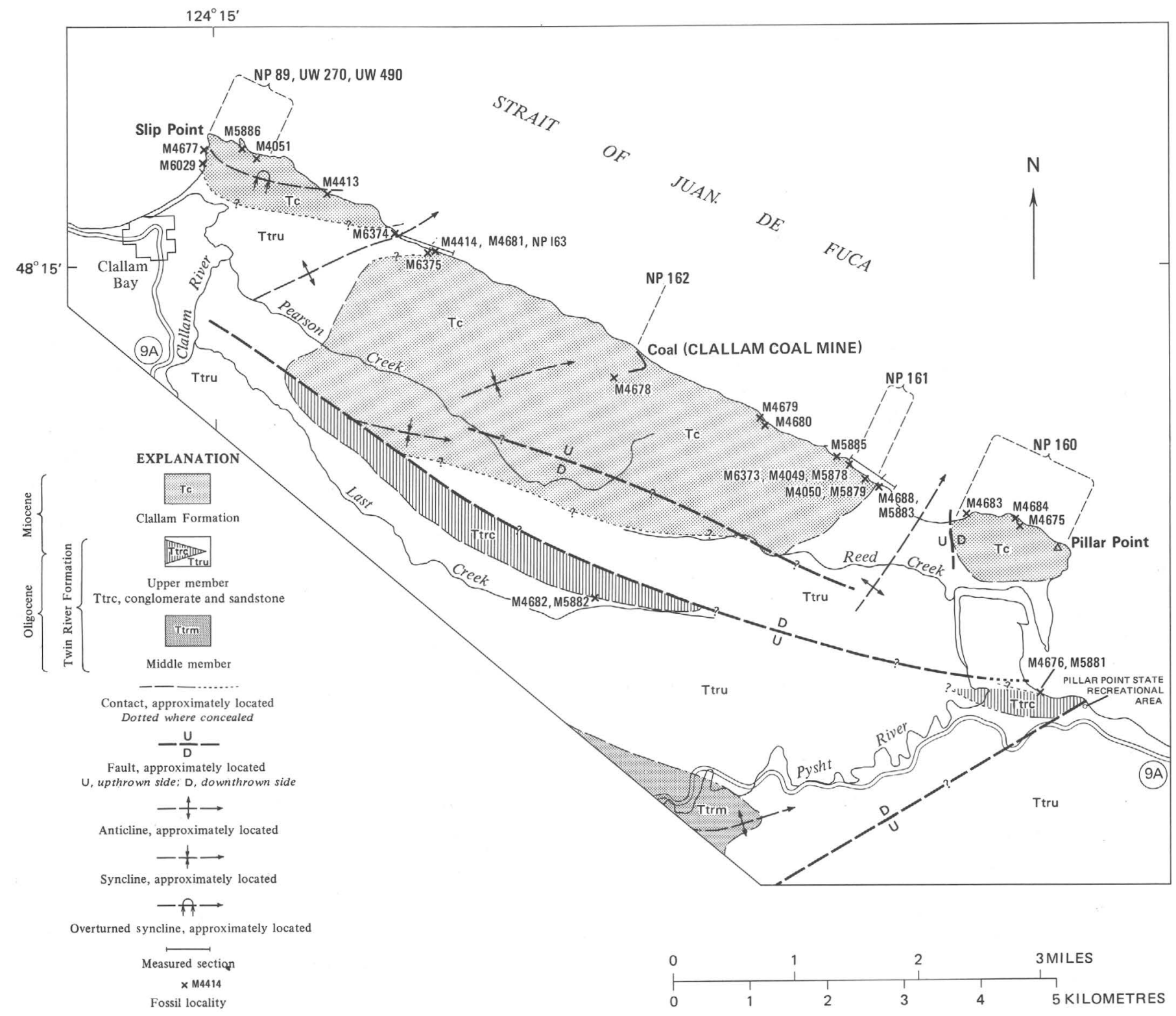

FiguRE 2.-Distribution of the Clallam Formation and fossil localities. Based on mapping by Gower (1960) with minor modifications made by Gower and Parke Snavely (written commun., January 1975).

The biostratigraphy of the Clallam is of especial interest because the formation serves as the type section for the Pillarian Stage (Addicott, 1976). It is also important in recognition and correlation of the boundary between the provincial lower and middle Miocene. The provincial early-middle Miocene boundary has been previously placed at the contact between the Clallam and the underlying Twin River Formation by Moore (1963), Addicott (1970a) and other molluscan specialists. Although there is a well-defined change in the megafauna across this boundary, evidence considered in this report suggests reassignment of the Clallam to the provincial early Miocene. Foraminiferal specialists, however, have generally placed the provin- cial Oligocene-Miocene boundary at the base of the Clallam Formation. This coastal section is well suited as a standard section because fairly diverse, shallowwater molluscan assemblages occur in both the Twin River and Clallam Formations. Benthonic foraminifers also occur across this boundary, permitting correlation with the provincial microfaunal chronology.

The geographic location of the Clallam Formation is especially critical in that it provides a potential biogeographic tie between Miocene assemblages of the Gulf of Alaska and Alaska Peninsula, far to the northwest, with those of the conterminous United States (lat $33^{\circ}-48^{\circ}$ N.). The Clallam assemblages define the northernmost occurrence of a late early Miocene mol- 
luscan province of relatively warm-water aspect in coastal Washington and Oregon. This province is characterized by a small, but persistent, element of mollusks that are closely related to species living in subtropical faunas at much lower latitudes along the Pacific coast.

A modern taxonomic evaluation of the currently known molluscan fauna is a necessary prelude to the biostratigraphic and biogeographic analyses. Although interest in the Clallam mollusks has spanned more than 70 years since they were first noted in connection with the discovery of coal seams near the top of the formation (Arnold, 1905), there has never been a thorough taxonomic or biostratigraphic treatment of the entire fauna. A generalized systematic study of the fauna was made by Reagan (1909) who recognized 25 mollusks in the Clallam, less than one-third the number now known from the formation.

Paleontologic sampling of the Clallam Formation for mollusks and other larger invertebrates during the period 1968-74 has yielded a fairly diverse fauna of 76 species of mollusks, about evenly divided between gastropods and pelecypods. Of the 11 taxa that are undescribed, only five are represented by specimens sufficiently well-preserved for formal description.

\section{ACKNOWLEDGMENTS}

I was aided in my fieldwork by Parke Snavely, Jr., Rowland Tabor, Norman MacLeod, Saburo Kanno, John Miller, and James Pearl. Howard Gower and Parke Snavely provided field maps and aerial photographs in addition to helpful discussions on the stratigraphy and geologic structure of the Twin River and Clallam Formations. Weldon Rau furnished data on foraminiferal assemblages from the Twin River and Clallam Formations. A. Myra Keen of Stanford University kindly lent material from the early collections made by Harold Hannibal (Arnold and Hannibal, 1913) for photography and laboratory study. V. Standish Mallory made available collections from the Burke Museum, University of Washington, for study. Saburo Kanno, Tokyo University of Education, Japan, furnished a specimen of Mytilus from Hokkaido for illustration here. The critical comments of Howard Gower, Ellen Moore, and Parke Snavely were beneficial. Fossil photography is by Kenji Sakamoto.

\section{PREVIOUS FAUNAL STUDIES}

Molluscan fossils of the Clallam Formation attracted the interest of several geologists during the early 1900 's after the discovery of coal seams near the top of the formation (Gilman, 1896; Arnold, 1905). Noteworthy are the reports of Ralph Arnold (1905, 1906, 1909, and 1913 [with Harold Hannibal] ), Albert B. Reagan (1909), and Charles E. Weaver (1912, 1916a, 1916b). These geologists briefly described the stratigraphic sequence of the Clallam Formation and also identified molluscan assemblages from the coastal area between Clallam Bay and Pillar Point. A few new mollusks were described from these exposures by Reagan (1909) and Weaver (1012). However, paleontologic investigation of the larger marine invertebrates of the Clallam has not passed beyond the reconnaissance phase. Virtually no additional work was done on the mollusks or their biostratigraphy during the ensuing 60 years. A few publications during this period, however, do contain incidental references to Clallam taxa (Tegland, 1929; Etherington, 1931; Slodkewtisch, 1938; Durham, 1944; Stirton, 1960; Moore, 1963; Addicott, 1969, 1970a). While interest in the Clallam mollusks languished, detailed taxonomic studies of the closely related Miocene fauna of the Astoria Formation of Oregon and southwestern Washington (Etherington, 1931; Moore, 1963) and the early and middle Miocene faunas of the Gulf of Alaska (Kanno, 1971) were completed. Although these are useful in working with the Clallam mollusks, the fauna of the Clallam contains many taxa not previously known from Miocene formations in the Pacific Northwest States and Alaska and is sufficiently unique to warrant systematic description and analysis.

Arnold (1906) included marine shale, sandstone, and conglomerate lying stratigraphically above the Eocene Crescent Formation in his original description of the Clallam Formation. Now almost all of this sequence is included in the Twin River Formation of Brown and Gower (1958). The name Clallam is retained for the uppermost part of this middle Tertiary sequence because Arnold designated exposures at the very top of his formation, between Clallam Bay and Pillar Point (fig. 2), as the type locality. He recognized five faunas [faunal assemblages] in his unrestricted Clallam Formation; only two are from the Clallam, as redefined here; the other three are from the underlying Twin River Formation. The two uppermost localities were near Slip Point (fig. 2); 18 mollusks were listed from them.

Reagan (1909) first described and illustrated molluscan fossils from the Clallam. Within the Clallam Formation as defined here, he recognized three successive faunal "horizons"-actually assemblages-from three localities at East Clallam [near Slip Point]. One of these was described as intermediate between Arnold's (1906) two localities that are from the redefined Clallam Formation. Twenty-seven of Reagan's (1909, p. 170-173) species were from these three Miocene localities in the Clallam. Six of these species, and a variant of Tellina arctata (Conrad) [= Macoma arctata 
TABLE 1.-Mollusks from the Clallam Formation near Slip Point listed by Reagan (1909, p. 172-173, and 181) with taxonomic revisions by Dall (1922) and names recognized in this report

[A larger list of mollusks from the Clallam Formation (Reagan, 1909, p. 197-198_east Clallam-Neah Bay series) includes many species from strata now mapped as Twin River Formation]

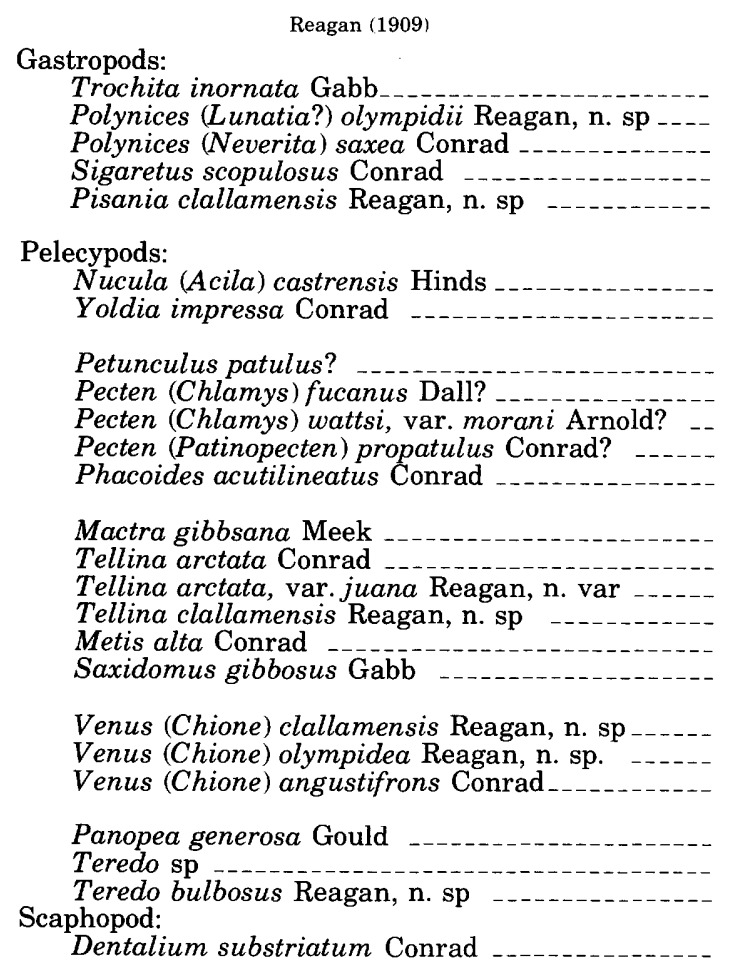

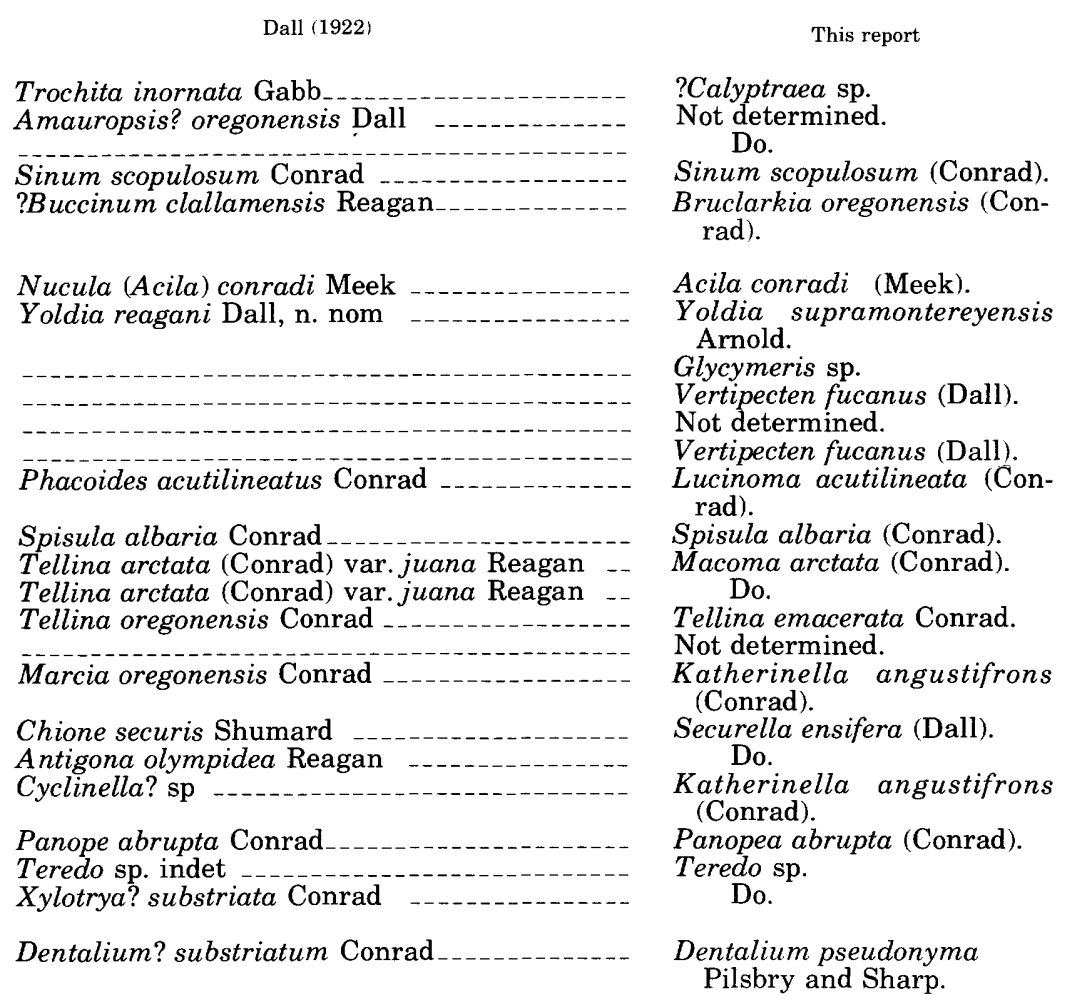

Conrad], were described as new. Dall (1922) reexamined the specimens that Reagan (1909, pls. 1-3) illustrated and made significant taxonomic revisions. These are correlated with names used in this report in table 1.

Subsequent study of other collections from the uppermost part of Arnold's (1906) Clallam Formation added a few more taxa to the known fauna; Arnold and Hannibal (1913) listed 34 species of mollusks from five localities in the Clallam, and Weaver (1916a) listed 43 species from two localities. Neither of these, nor any of the subsequent reports in which Clallam mollusks have been listed (Etherington, 1931; Durham, 1944; Moore, 1963), dealt specifically with the biostratigraphy of the formation or the molluscan taxonomy.

Relatively little work has been done on other kinds of marine organisms from the Clallam Formation. A few benthonic foraminifers have been recorded from the Clallam by Rau (1964); these, and stratigraphic relations, suggest assignment of the Clallam to the Saucesian Stage of Kleinpell (1938). A marine carnivore was described from the Clallam Formation by Stirton (1960) who also noted the occurrence of cetacean bones and shark teeth.

Late Paleogene and Neogene provincial molluscan stages for the Pacific Northwest States and western
Canada were described in two reports published after this manuscript was completed (Armentrout, 1975, and Addicott, 1976). Unfortunately processing of this manuscript had reached a stage where only limited referencing of these stages was feasible following final editing and completion of the artwork.

\section{MOLLUSCAN FAUNA}

Collections obtained during this investigation have tripled the size of the previously known fauna of the Clallam Formation. Among the previously unreported mollusks are a few newly described speciesSemicassis pyshtensis, Priscofusus goweri, P. slipensis, Ophiodermella olympicensis, and Solamen snavelyi. In addition, six other mollusks appear to be undescribed but are represented by poorly preserved material inadequate for formal description. In all, 76 molluscan taxa are identified from the Clallam (table 2).

Taxonomically, gastropods and pelecypods are about evenly represented in the Clallam Formation: 34 gastropod and 39 pelecypod taxa. In some assemblages, however, there may be twice as many species of pelecypods as gastropods, and in individual collections pelecypods usually far outnumber gastropods in numbers of individual specimens. 
MOLLUSCAN FAUNA

TABLE 2.-Mollusks from the Clallam Formation, northern Olympic Peninsula, Wash. [ $\times$, present as identified; cf., similar form; aff., comparable but apparently different form; ?, doubtful identification]

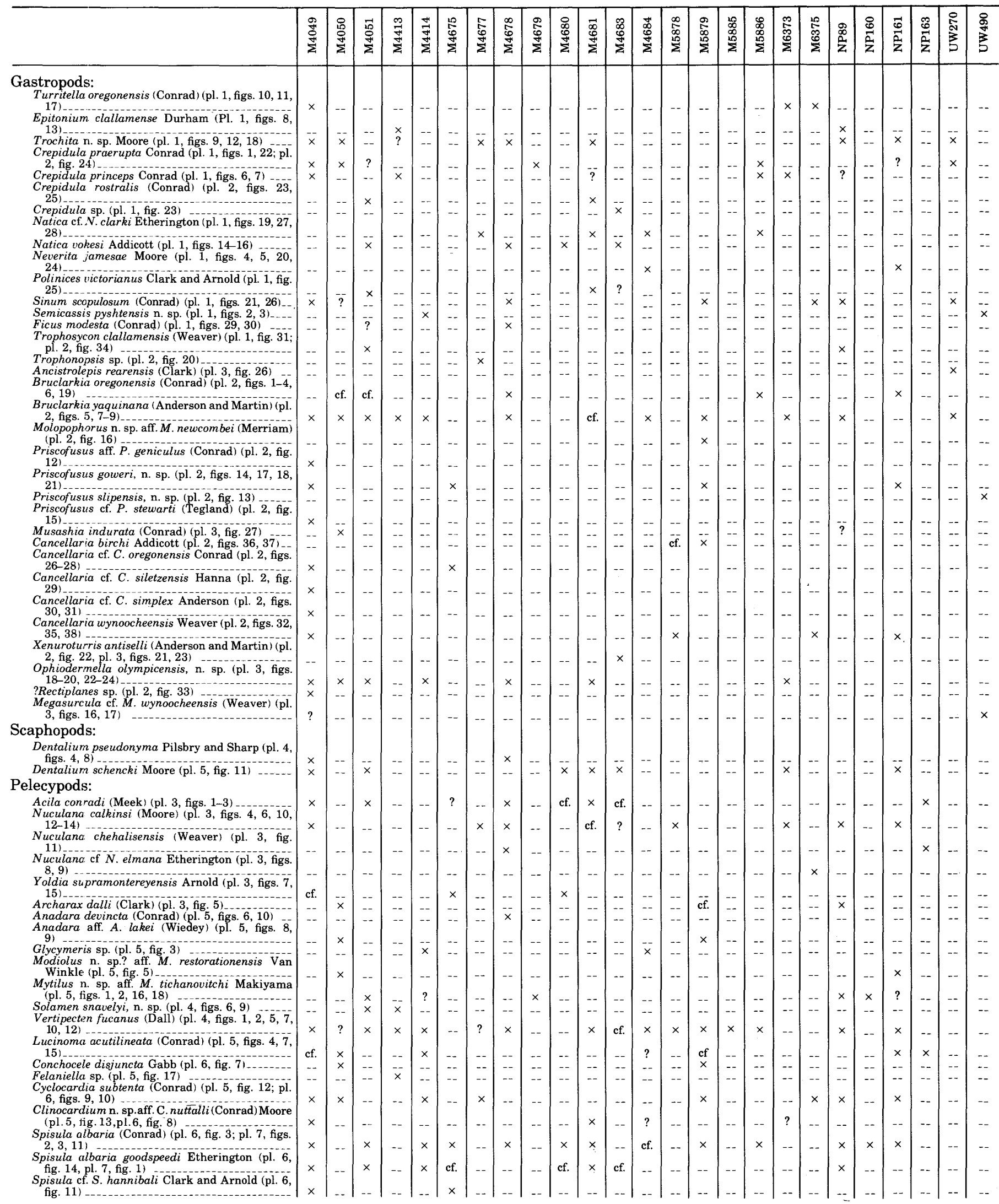


TABLE 2.-Mollusks from the Clallam Formation, northern Olympic Peninsula, Wash.-Continued

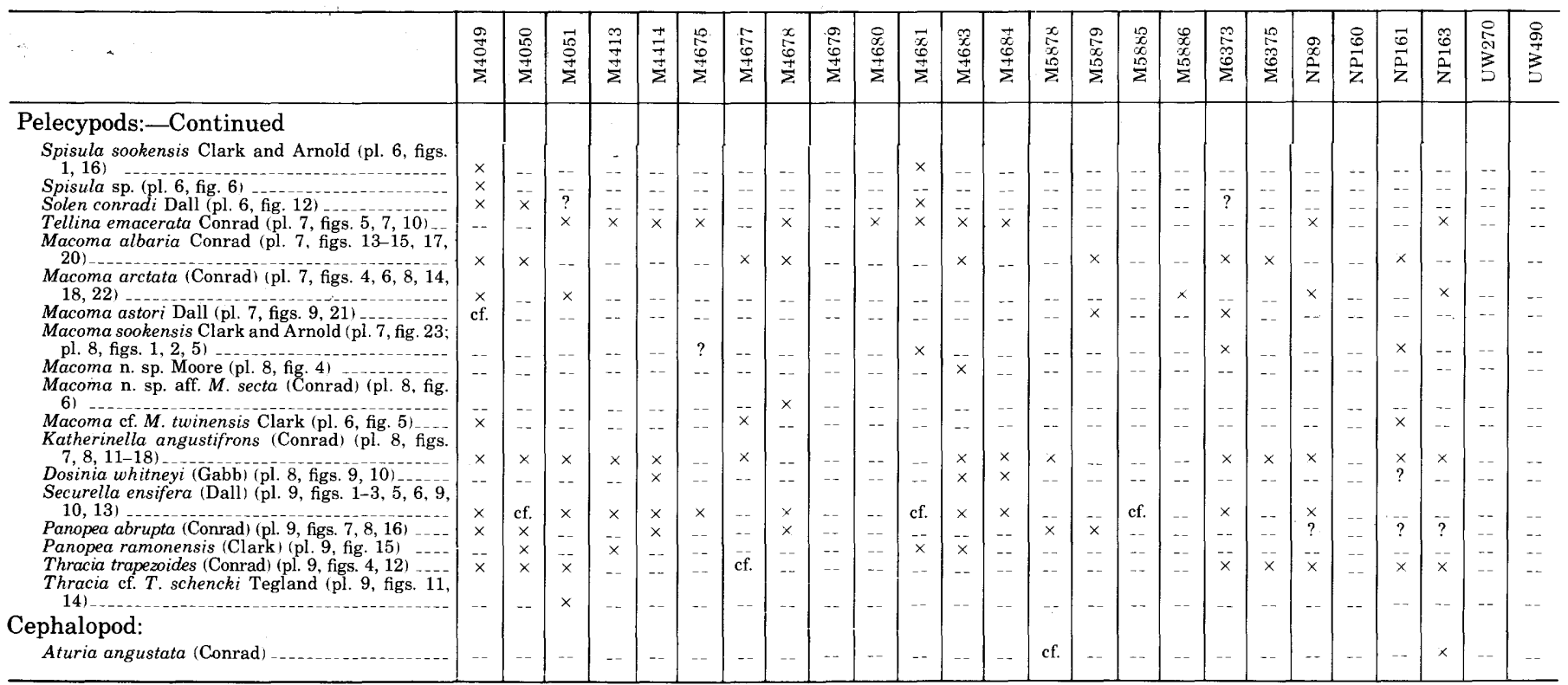

Most of the Clallam genera are monospecific. A few genera, however, include several species each: Macoma, Spisula, Crepidula, Priscofusus, and Cancellaria. Appreciable taxonomic diversity within these genera is not unusual in early and middle Miocene molluscan faunas of the middle latitudes (Loel and Corey, 1932; Moore, 1963; Addicott, 1970b).

The generally poor preservation of shell material is an important factor in the systematic study of the Clallam molluscan fauna. Only in the silty, very fine to fine-grained sandstones of the lowest part of the Clallam Formation (fig. 3) are the aragonitic-shelled species preserved with original shell material. The few calcitic-shelled mollusks, such as the mytilids and the pectinids, are preserved with shell material. They constitute slightly more than 5 percent of the fauna. In many localities, however, internal molds of both bivalves and gastropods are preserved with fair to very good representation of the original surface sculpture. Most of the gastropods illustrated here are totally devoid of shell material but nevertheless, exhibit sufficiently detailed sculpture to permit confident specific identification.

\section{BIOSTRATIGRAPHY}

\section{INTRODUCTION}

Molluscan assemblages from the Clallam Formation are especially significant in the chronostratigraphic classification and correlation of the lower part of the Neogene sequence of the Pacific Northwest States. The Clallam forms the biostratigraphic base for a recently recognized provincial stage of early Miocene age, the Pillarian Stage (Addicott, 1976). New biostratigraphic data from the present study permitted recognition and definition of this stage and, for the first time, determination of the boundary between it and the underlying Juanian Stage, a unit that is coeval with the upper parts of the so-called Blakeley Stage (Weaver and others, 1944, chart 11) and the Matlockian Stage (Armentrout, 1975). Heretofore, there was a sizeable gap in faunal control between the type section of the upper part of the "Blakeley" Stage and the stratigraphically higher molluscan assemblages of the Clallam Formation (the type section of the Echinophoria apta zone (Durham, 1944) in the upper part of the upper member of the Twin River Formation forms the biostratigraphic basis for the upper part of the "Blakeley" Stage). Recent collections from a previously unrecognized fossiliferous interval of a few hundred metres thickness at the top of the Twin River Formation (USGS locs. M4676, M4682, M4688, M5881, M5882, M6374) show that the boundary between these two lower Miocene stages, the Juanian and the Pillarian, is at, or very close to, the contact between the Twin River and Clallam Formations.

\section{CLALLAM FORMATION}

The Clallam Formation was described by Arnold (1906) who included the entire stratigraphic sequence lying above the Eocene Crescent Formation in his unit. The name was subsequently abandoned by Arnold and Hannibal (1913) who substituted the term Monterey Formation for the uppermost $600 \mathrm{~m}$ of the postCrescent sequence. Their lignitic sandstone exposed near Clallam Bay includes strata later assigned to the Clallam Formation (Brown and Gower, 1958; Gower, 1960). The lower part of Arnold's (1906) Clallam For- 


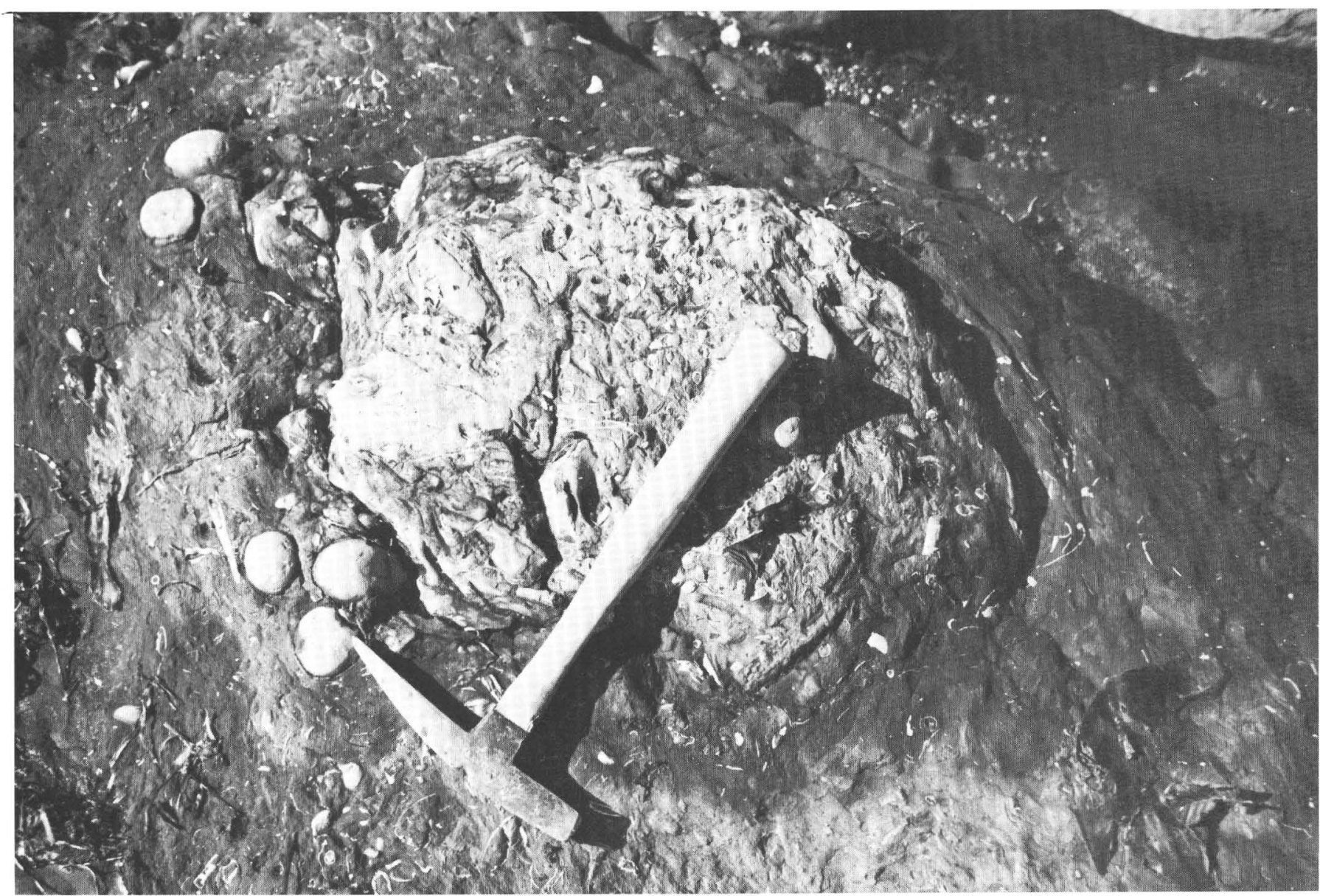

FIGURE 3.-Intertidal zone exposure of Dentalium-bearing concretionary fine-grained sandstone (USGS loc. M4049) in lower part of the Clallam Formation about $3 \mathrm{~km}$ west-northwest of Pillar Point.

mation has a complex nomenclatorial history (Arnold and Hannibal, 1913; Weaver, 1937). Current usage places the basal sandstone and conglomerate overlying the Crescent in the Lyre Formation (Brown and others, 1956) and the stratigraphically higher sequence of argillaceous rock in the Twin River Formation (Brown and Gower, 1958). These units have a combined maximum thickness of about $6,300 \mathrm{~m}$.

The name Clallam is here retained for strata exposed between Slip Point, on the west, and Pillar Point, on the east, in keeping with Arnold's (1906) original designation of strata at the very top of his formation in this area as the type locality. As recognized here conglomerate and sandstone exposed between Last Creek and Reed Creek and along the coast from the village of Seiku westward about $5 \mathrm{~km}$ to the mouth of Hoko River are reassigned to the upper member of the Twin River Formation. The strata in the latter area were included by Weaver (1937, p. 173) in the Clallam Formation. In both areas the strata contain clasts of fossiliferous sandstone from which an assemblage of early Miocene mollusks referable to the Echinophoria apta zone of Durham (1944) has been collected. Sandstone at the top of the conglomerate near the mouth of Pysht River (USGS loc's. M4676 and M5881) contains in situ mollusks that suggest assignment to the $E$. apta zone. Molluscan assemblages from the uppermost $40 \mathrm{~m}$ of the Twin River Formation (fig. 4; USGS loc's. M4688, M5883, and M6374) differ appreciably from the fauna of the Clallam Formation. One species, Turritella yaquinana Addicott, suggests correlation with rocks in Oregon referable to the E. apta zone. Concurrent ranges of several other species point to a provincial early Miocene age and inclusion in the E. apta zone even though the zonal index species does not occur in these assemblages.

The Clallam is estimated to be as thick as $600-800 \mathrm{~m}$ (Weaver, 1937; Gower, 1960). It is dominantly marine sandstone (fig. 5), but it also contains sandy siltstone and, locally, granule to cobble conglomerate (fig. 6). Thin coal beds and carbonaceous siltstone exposed in a synclinal structure near the top of the formation (Gower, 1960) indicate nonmarine deposition. The contact with the underlying sandy siltstone of the Twin 


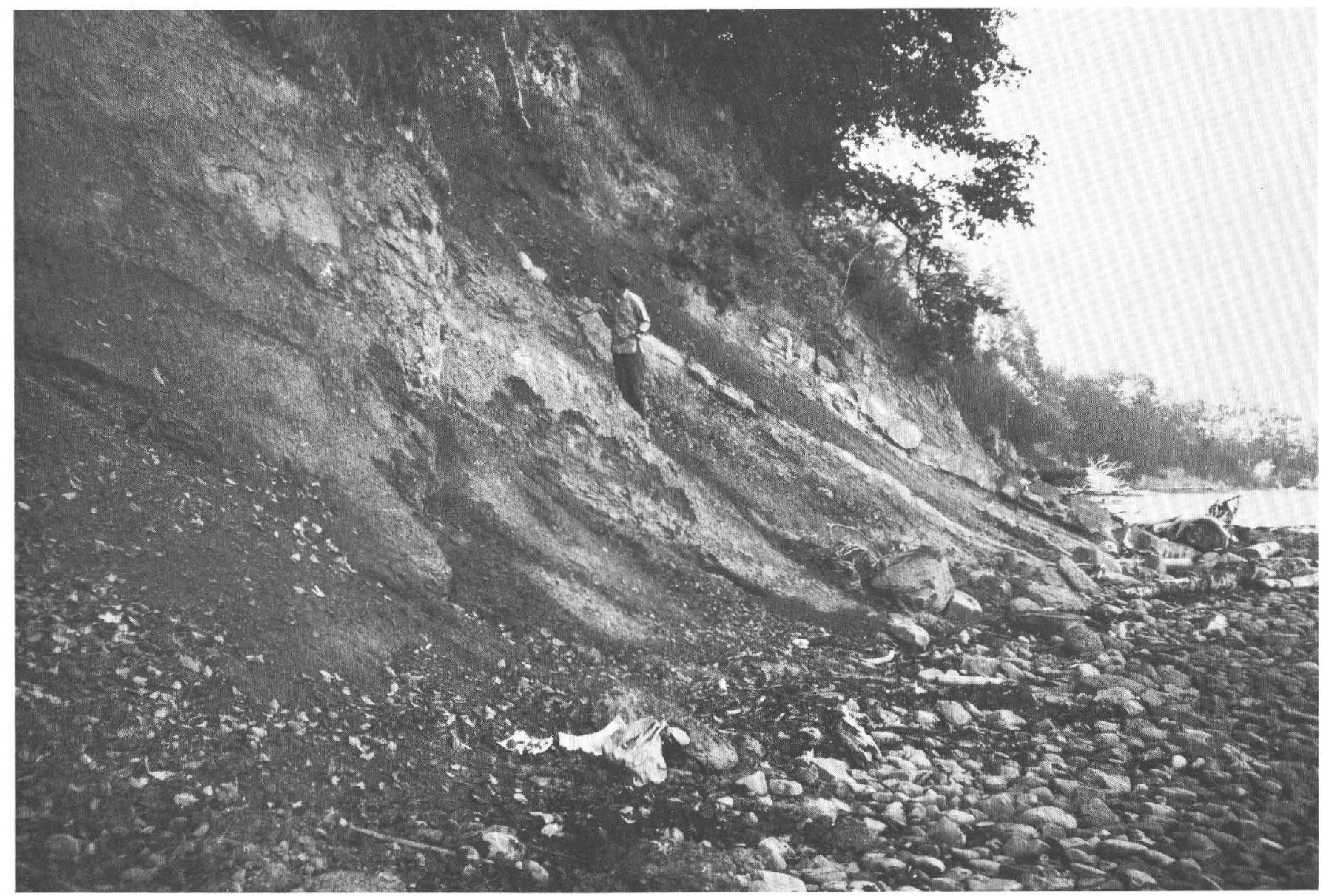

FigURE 4.-Massive, fossiliferous (USGS loc. M4688) sandy siltstone at top of the upper member of the Twin River Formation about 2.5 km west-northwest of Pillar Point. Base of 1-m-thick sandstone at right edge of photograph marks the base of the Clallam Formation.

River Formation is conformable and gradational (fig. 7). It is well exposed on the west flank of the anticline near Pillar Point and, also, on the east flank of the anticline near Slip Point. There is no evidence of an unconformity between the two formations as reported by Weaver (1942, p. 131, 174-175). The top of the Clallam is not exposed.

Folding, faulting, and penecontemporaneous deformation in some segments of the coastal exposures of the Clallam Formation make it difficult to place many of the fossiliferous strata in stratigraphic succession and also preclude accurate determination of the overall thickness of the formation. Nevertheless, exposures of the lowest $240 \mathrm{~m}$ of the formation on the facing flanks of the two anticlines between Slip Point and Pillar Point (fig. 2) are relatively undisturbed. Stratigraphic sections (fig. 8) measured on the facing flanks of these two structures indicate that the contact between the Twin River Formation and the Clallam tends to be gradational. Exposures on the east flank of the anticline west of Pillar Point, however, are bounded by a fault (Gower, 1960) and include some giant, house-size rotated blocks that preclude determination of the stratigraphic position of the fossiliferous strata near Pillar Point. The top of the measured section on the west flank of this anticline is marked by a zone of severely brecciated sandstone (fig. 3) that marks an east-west-trending fault. To the west of this fault there are some giant rotated blocks of sandstone (fig. 9) with a few fossiliferous strata (USGS locs. M4679 and M4680) of undetermined stratigraphic position. Strata on the northwest flank of the anticline east of Slip Point generally strike in an east-west direction and appear to be less disturbed than strata at the east end of the outcrop belt.

Fossiliferous strata on the east flank of the anticline near Slip Point (USGS locs. M4414 and M4681) and on the west flank of the anticline near Pillar Point (USGS locs. M4050, M5879, M4049, M5878, M5885) can be arranged stratigraphically with a considerable degree of precision (fig. 8).

Several other assemblages seem to be from this part of the Clallam Formation but they cannot be located with confidence. Although the contact of the Clallam 


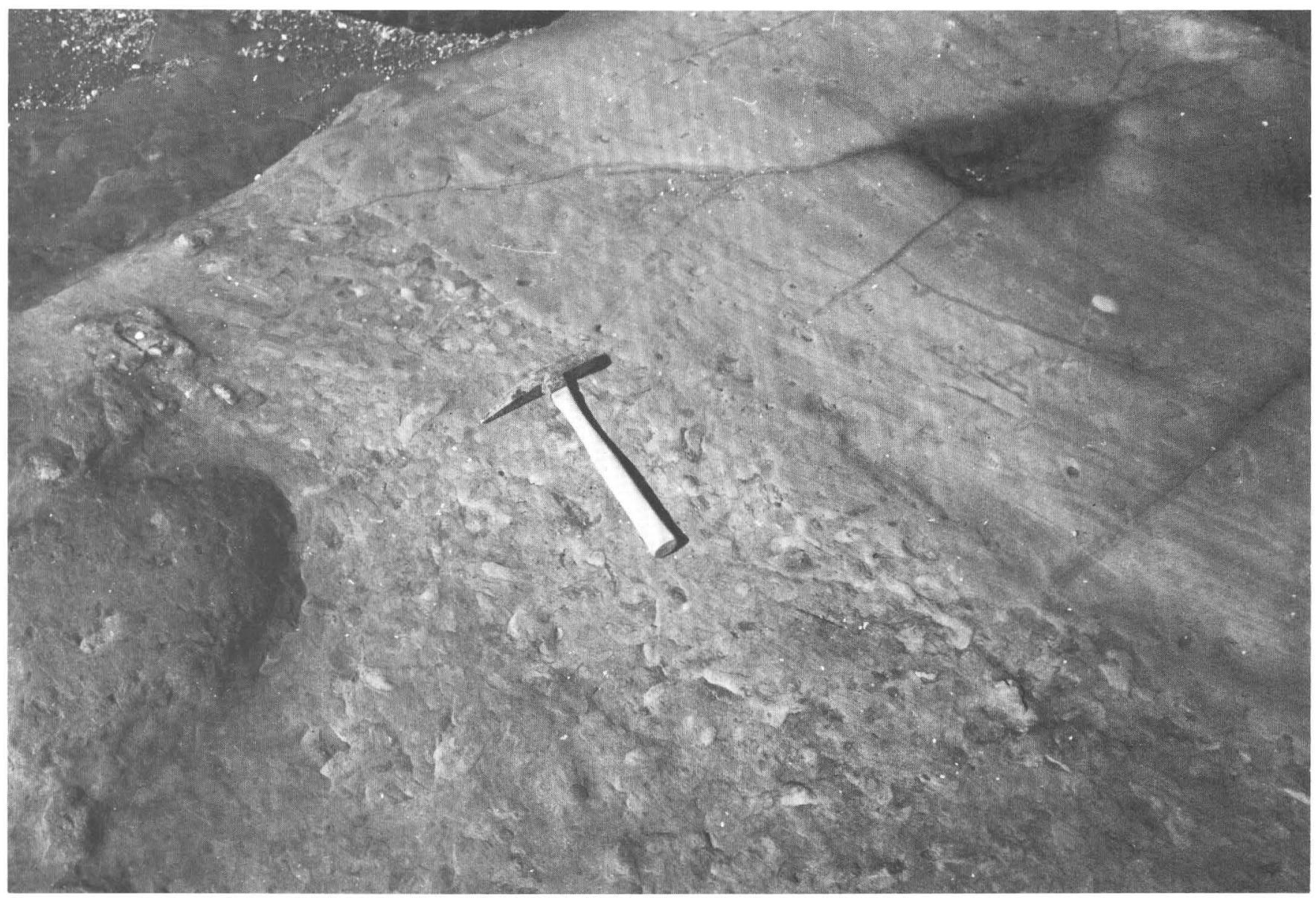

FIGURE 5.-Intertidal zone exposure of the Clallam Formation showing intensively bioturbated fine- to medium-grained marine sandstone overlain by finely laminated sandstone with scattered biogenic structures. Locality is about $220 \mathrm{~m}$ above the base of the Clallam Formation and $3 \mathrm{~km}$ west-northwest of Pillar Point.

with the Twin River is not exposed on the south limb of the overturned syncline at Slip Point (fig. 2), the stratigraphic position of two localities there (M6029 and M4677) are estimated to be about 130 and $180 \mathrm{~m}$, respectively, above the base of the formation. The contact of the Clallam with the Twin River Formation is not exposed on the faulted north limb of the syncline at Slip Point (fig. 2), but localities there (M4051, M4413, and M5886) may be in the lowest 100 to $300 \mathrm{~m}$ of the formation, judging by lithologic similarity to better known sections.

The stratigraphic position of the other fossiliferous localities cannot be determined with certainty. One of these (M4678), however, seems to be at or near the top of the formation judging by its position near the apparent axis of the broad synclinal structure (Weaver, 1937, pl. 14; Gower, 1960) about midway between Slip Point and Pillar Point.

In view of the structural complications, the Clallam assemblages are placed in two broadly defined strati- graphic packages based on geologic mapping by Gower (1960). One includes the tectonically undisturbed basal $240 \mathrm{~m}$ of the formation that conformably overlie the Twin River Formation; the second includes a single locality (M4678) near the top of the formation at an undetermined interval above the lower unit, possibly as much as $800 \mathrm{~m}$ (Gower, 1960). Several localities can be confidently placed in stratigraphic sequence in the basal part of the Clallam (fig. 8), as previously shown, but most cannot. Most, if not all, of these other assemblages, however, are similar to the material from the lower part of the Clallam and may well represent that part of the formation.

There is a distinct faunal hiatus between molluscan assemblages of the upper member of the Twin River Formation and those of the Clallam Formation. Nearly two-thirds of the specifically determined mollusks from the Clallam (table 3) are not known to occur in the Twin River or in coeval early Miocene, or older, faunal assemblages. This faunal hiatus is attributed to the 


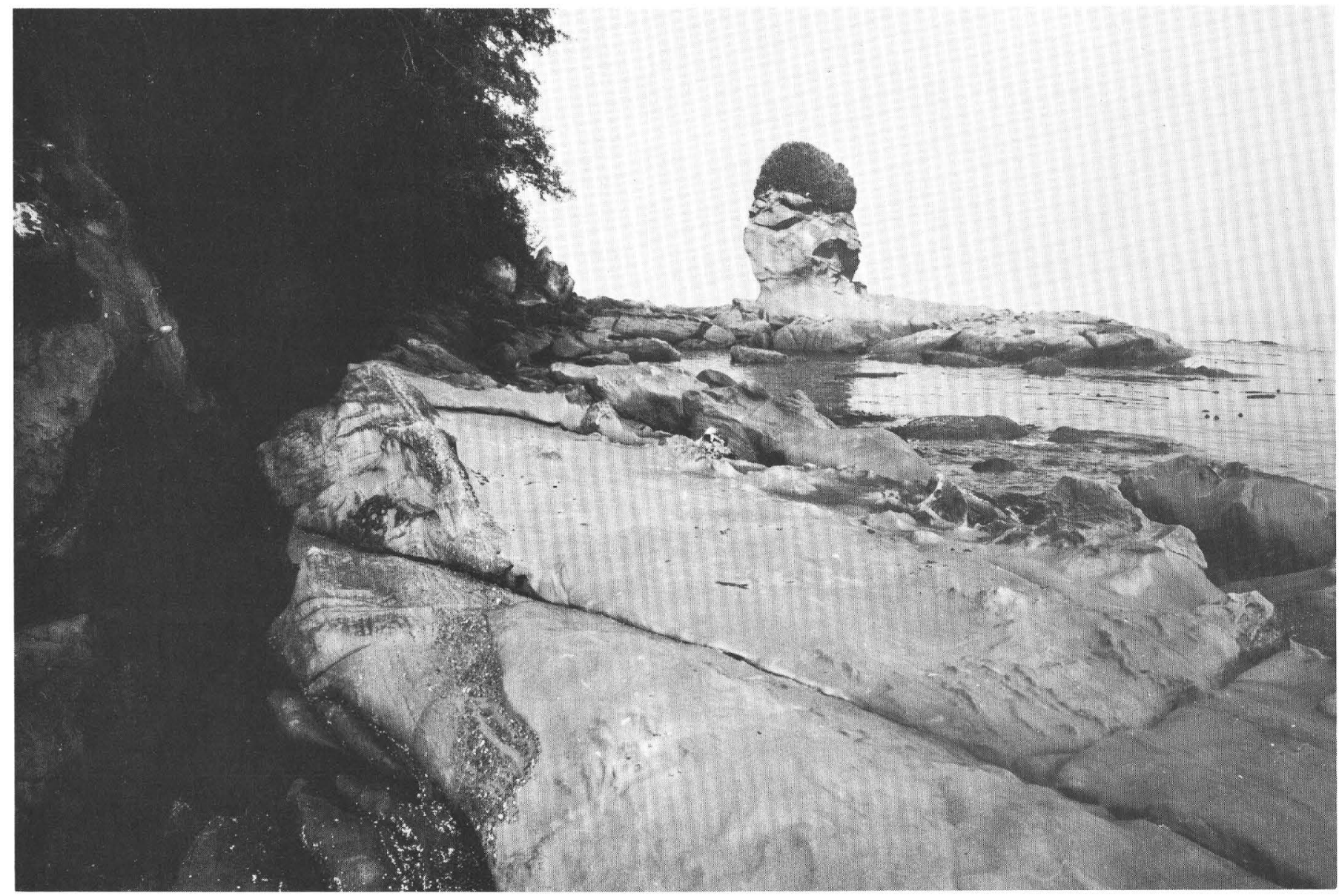

FIGURE 6.-Steeply dipping conglomerate and conglomeratic sandstone lens in the Clallam Formation that form a prominent point about $2.5 \mathrm{~km}$ east-southeast of Slip Point. View northwest.

significantly greater taxonomic diversity of the Clallam fauna, a reflection of the much warmer and shallower water environment.

Several mollusks are unique to the Clallam Formation (table 4) and, for this reason, are of potential value biostratigraphically. Among these are new species described here as well as several taxa represented by individual specimens, or by poorly preserved material, that differ significantly from known species and that probably are new. Another species that occurs in the Clallam, and that is restricted in stratigraphic occurrence to coeval strata in Oregon, is Vertipecten fucanus. This distinctive giant pectinid, which occurs in more collections than any other species, is perhaps the most characteristic mollusk in the Clallam. Its restricted stratigraphic occurrence in the middle Tertiary sequence of coastal Oregon suggests that it can serve as a zonal index for part of the provincial early Miocene.

The Clallam is best characterized biostratigraphically by the unique co-occurrence of several species that are also known from younger or older strata in western Washington and western Oregon. Species that appear in older stratigraphic units but that do not range into strata younger than the Clallam include: Archarax dalli (Clark), Spisula hannibali Clark and Arnold, S. sookensis Clark and Arnold, Macoma twinensis Clark, Thracia schencki Tegland, Priscofusus stewarti (Tegland), and Ancistrolepis rearensis (Clark). Many species that have their lowest occurrence in the Clallam also occur in stratigraphically younger parts of the Astoria Formation of Oregon and southwestern Washington (table 3). Others that have their lowest occurrence in the Clallam and that range into strata of late Miocene age or higher include: Crepidula princeps Conrad, Spisula albaria goodspeedi Etherington, and Macoma astori Dall. Some of the species in these groups from the Clallam Formation are doubtfully identified.

Mollusks that are characteristic of the Clallam Formation in terms of frequency of occurrence are given in table 5. Most of these have a stratigraphic distribution that is limited to the Clallam and to the middle Miocene Astoria Formation of Oregon, as indicated in the table. One pelecypod, Vertipecten fucanus (Dall), is 


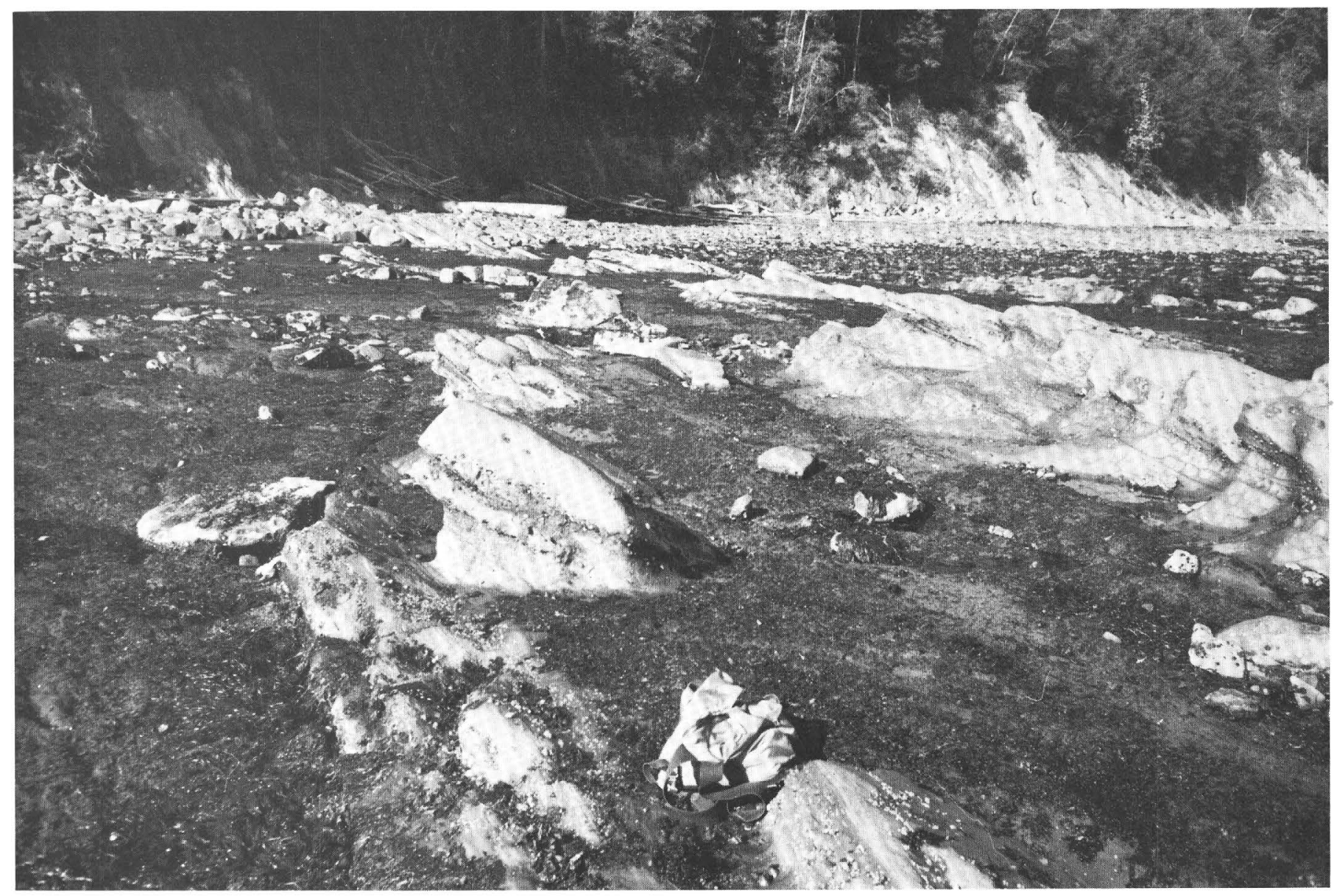

FIGURE 7.-Intertidal zone exposures of basal 14-m-thick fine-grained concretionary sandstone of the Clallam Formation about $2.5 \mathrm{~km}$ west-northwest of Pillar Point. Sandstone at right edge of photograph is $2 \mathrm{~m}$ thick. View southwest.

restricted to the Clallam and to the coeval late early Miocene Nye Mudstone as well as other formations of this age.

Analysis of the few assemblages from tectonically undisturbed sections in the lowest $240 \mathrm{~m}$ of the Clallam Formation indicates certain faunal changes that may be of local biostratigraphic significance. Several species from the lowest parts of the Clallam do not range into stratigraphically higher assemblages.

Collections from the basal $60 \mathrm{~m}$ of the Clallam (locs. M4050 and M5879) contain several mollusks restricted to this stratigraphic interval: Archarax dalli (Clark), Anadara aff. A. lakei (Wiedey), Modiolus n. sp.? aff. M. restorationensis Van Winkle, Conchocele disjuncta Gabb, and Musashia indurata (Conrad). This collection is from a moderately deep sublittoral assemblage, significantly deeper than stratigraphically higher ones in the Clallam. The absence of these species from higher assemblages in the Clallam, together with the appearance of many shallow inner sublittoral mollusks, points to a shallowing of the depositional environment. This change of bathymetric facies reflects the regres- sive phase of an Eocene to Miocene depositional cycle in northwestern Washington.

Faunal change in the stratigraphically higher assemblage from locality M4414, which is believed to be from a somewhat higher stratigraphic position (fig. 8) seems to reflect continued shallowing of the depositional environment. This assemblage is smaller than that from M4050 and M5879, yet more than half of the taxa are not represented in the stratigraphically lower collections. It is composed principally of inner sublittoral bivalves that reflect the inferred shallowing of the depositional environment. Only one species, Semicassis pyshtensis n. sp., is restricted to this assemblage.

By far the largest assemblage from the Clallam is from a stratigraphic interval about $190-210 \mathrm{~m}$ above the base of the formation (locs. M4049 and M5878). Several species are restricted to this interval: Clinocardium n. sp. aff. C. nuttalli (Conrad) Moore, Macoma cf. M. twinensis Clark, Priscofusus aff. $P$. geniculus (Conrad), Priscofusus cf. P. stewarti (Tegland), Cancellaria ef. C. siletzensis Hanna, C. cf. C. 


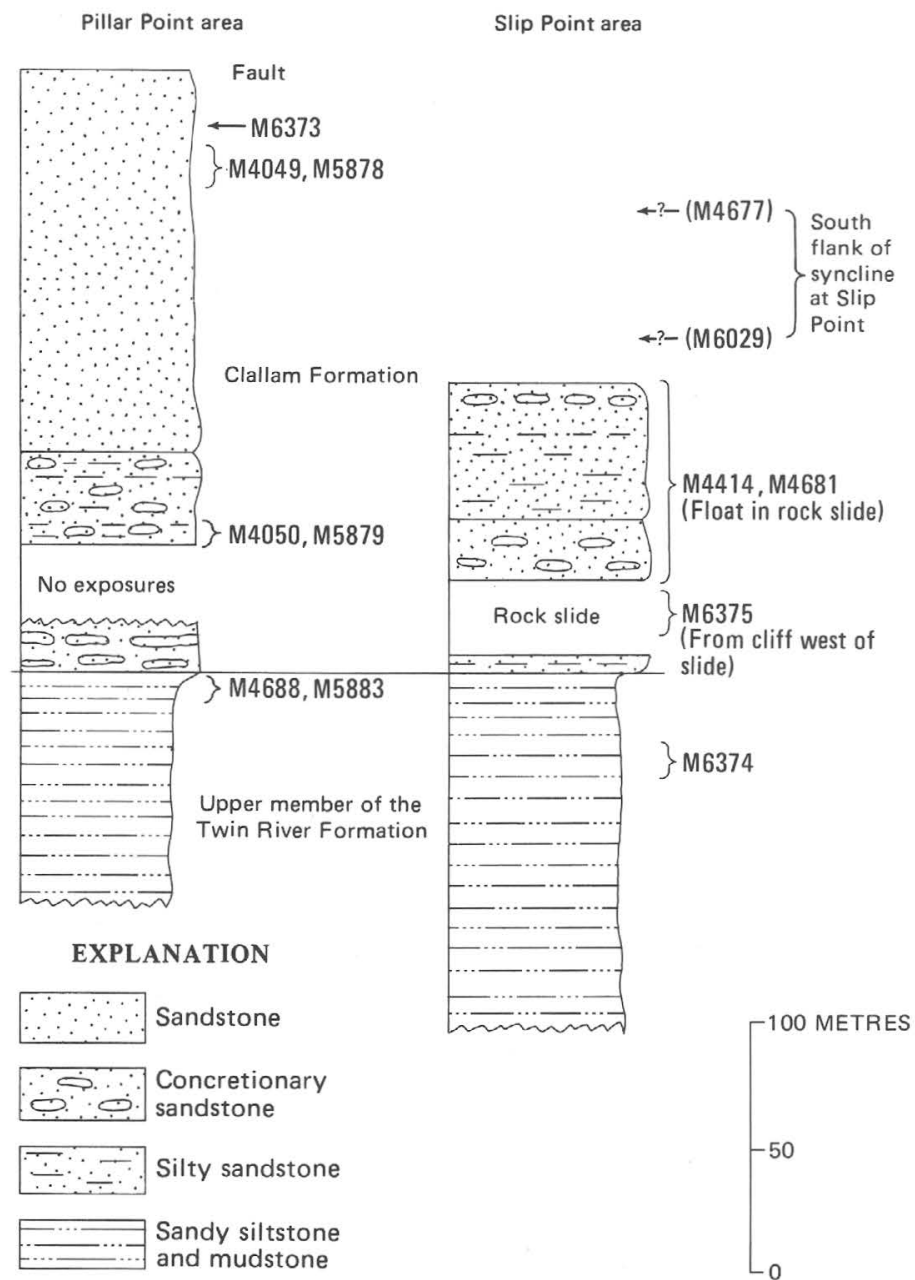

FIGURE 8.-Stratigraphic position of fossil localities in measured sections of the Twin River and Clallam Formation near Pillar Point and Slip Point.

simplex Anderson, and C. wynoocheensis Weaver. The presence of so many seemingly restricted species is directly related to the unusually large number of species in the assemblage. It probably also reflects the commingling of mollusks from different communities, in asmuch as this assemblage is from layered shell accumulations possibly brought together by storm waves whereas those from almost all of the other localities in the Clallam consist of widely scattered mollusks deposited in place.

Differences between these collections from the lowest $200 \mathrm{~m}$-those from the basal $60 \mathrm{~m}$ and those from 190 to $210 \mathrm{~m}$ - of the Clallam may prove useful in characterization and recognition of units within the lower part of the formation. However, because they seem to be influenced, to a large degree, by progressive shallowing and, perhaps, warming of the depositional environment, regional chronologic significance cannot be attached to them.

The small assemblage from what is believed to be the upper part of the Clallam Formation (loc. M4678), about midway between Pillar Point and Slip Point, has only three species that do not occur in collections from the lower part of the formation. One is a poorly known tellinid, Macoma n. sp. aff. M. secta (Conrad). Another, a split-ribbed form of Anadara devincta (Conrad), which occurs elsewhere in strata assigned to the Pillarian Stage is not, therefore, indicative of a significantly younger age than assemblages from the lower part of the Clallam. The third species, Nuculana chehalisensis (Weaver), is known from middle Miocene strata in Oregon and California.

This highest collection from the Clallam is not considered to represent a distinct biostratigraphic unit, as there is a very close similarity, if not identity, with assemblages from the lower part of the formation. Accordingly, all the faunal assemblages from the Clallam are here regarded as representing a single biostratigraphic unit, of late early Miocene provincial age, correlative with the upper part of the "Vaqueros" Stage of California.

\section{PROVINCIAL GHRONOSTRATIGRAPHY}

\section{AGE AND CORRELATION}

Molluscan specialists have generally assigned the Clallam Formation to the provincial middle Miocene. There is a very strong resemblance between the Clallam molluscan assemblages and the well-known middle Miocene molluscan fauna of the Astoria Formation of Oregon, a fact long evident to stratigraphers (Arnold, 1906; Arnold and Hannibal, 1913; Etherington, 1931). Many species in the Clallam also occur in the fauna of the "Temblor" Stage of central California, the standard for the provincial middle Miocene, therefore some specialists considered the Clallam to be coeval with the "Temblor" Stage (Arnold and Hannibal, 1913; Etherington, 1931; Durham, 1944; Addicott, 1969). Until now, however, data on the Clallam fauna were so few that correlation with the California sequence was doubtful (Addicott, 1970a, p. 36).

The stratigraphic occurrence of several of the mollusks now known from the Clallam (table 6) suggests that the formation is of provincial early Miocene age. These assemblages indicate correlation with the upper part of the "Vaqueros" Stage of the California Coast Ranges. This relation is implicit in the foraminiferal correlations between the Clallam Formation and California Coast Range sections based on benthonic assemblages (Kleinpell, 1938; Rau, 1964). Still, most, if not all, of the previous age assignments of the Clallam by molluscan specialists (Etherington, 1931; Durham, 1944; Moore, 1963; Addicott, 1967, 1969, $1970 \mathrm{~b}$ ) have been middle Miocene, or have implied a 


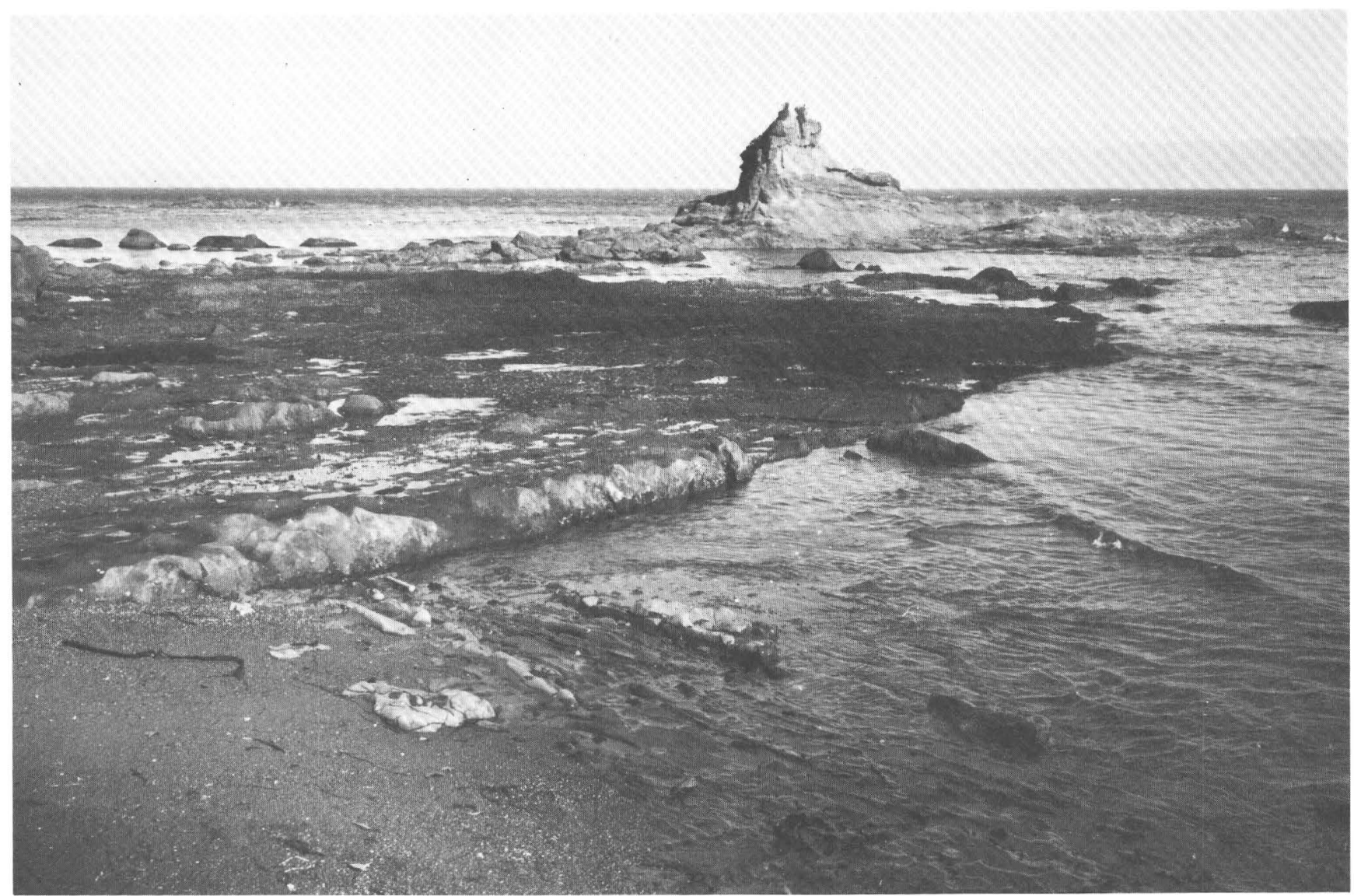

Figure 9.-Chaotic blocks of sandstone in intertidal zone exposure of the Clallam Formation about $1 \mathrm{~km}$ west of triangulation station at Pillar Point. Concretionary bed extending from lower left toward upper right defines a west-northwest dipping block underlain by a north-northeast dipping block in the lower right indicated by concretionary lenses striking toward lower right hand corner of photograph. View north.

only from the late Oligocene and early Miocene "Blakeley" or Matlockian Stage of this region.

Two other bivalves are more diagnostic of provincial age and correlation. Mytilus n. sp. aff. $M$. tichanovitchi is known elsewhere in the eastern North Pacific only from the early Miocene "Vaqueros" Stage of California (Allison and Addicott, 1976). This rugose species has sometimes been confused with the middle Miocene index M. middendorffi (Allison and Addicott, 1976), a species that may be its progeny. The more commonly occurring and more widespread pectinid, Vertipecten fucanus, provides the strongest evidence of an early Miocene age in terms of the mega-invertebrate sequence. According to J. T. Smith (oral commun., September 1974: UCMP loc. B1660), this species occurs in the lower Miocene Jewett Sand of the San Joaquin basin, California, a unit that also carries lower Saucesian benthonic foraminifers. In the Newport Embayment of the northwestern Oregon coast, $V$. fucanus appears in the early Miocene (Addicott, 1974) and occurs stratigraphically below Patinopecten propatulus, a wide- 
TABLE 3.-Stratigraphic ranges of species from the Clallam Formation in the Pacific Coast Tertiary

[Ranges indicated by a dotted line (...) are of species not known to occur in other formations. No attempt is made to show relative stratigraphic occurrence within the Clallam. Ranges shown for doubtfully identified mollusks (i.e., Natica cf. $N$. clarki) indicate the known stratigraphic occurrence of the unequivocably identified species. Pacific Northwest stages are from Armentrout (1975) and Addicott (1976)]

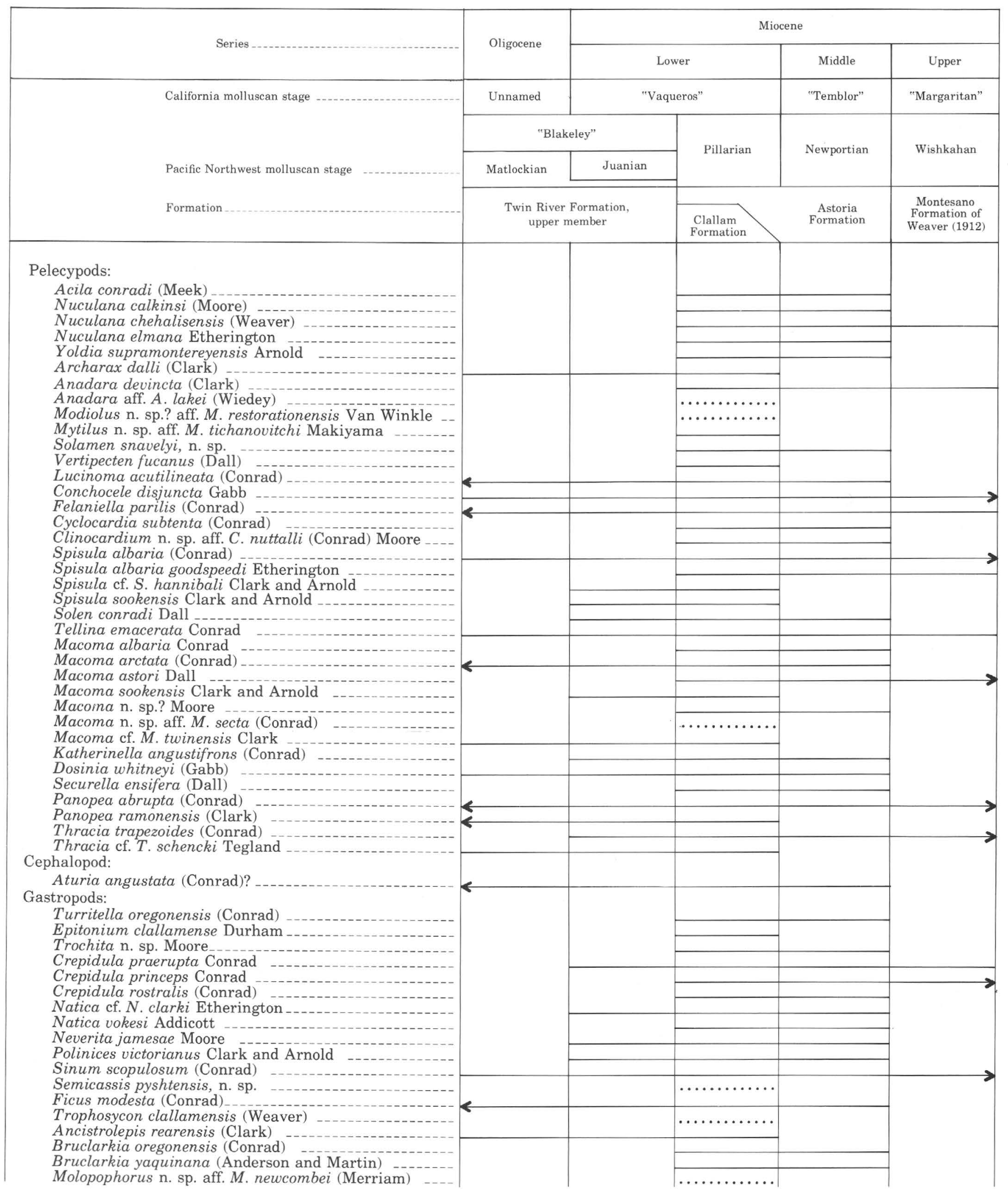


TABLE 3.-Stratigraphic ranges of species from the Clallam Formation in the Pacific Coast Tertiary-Continued

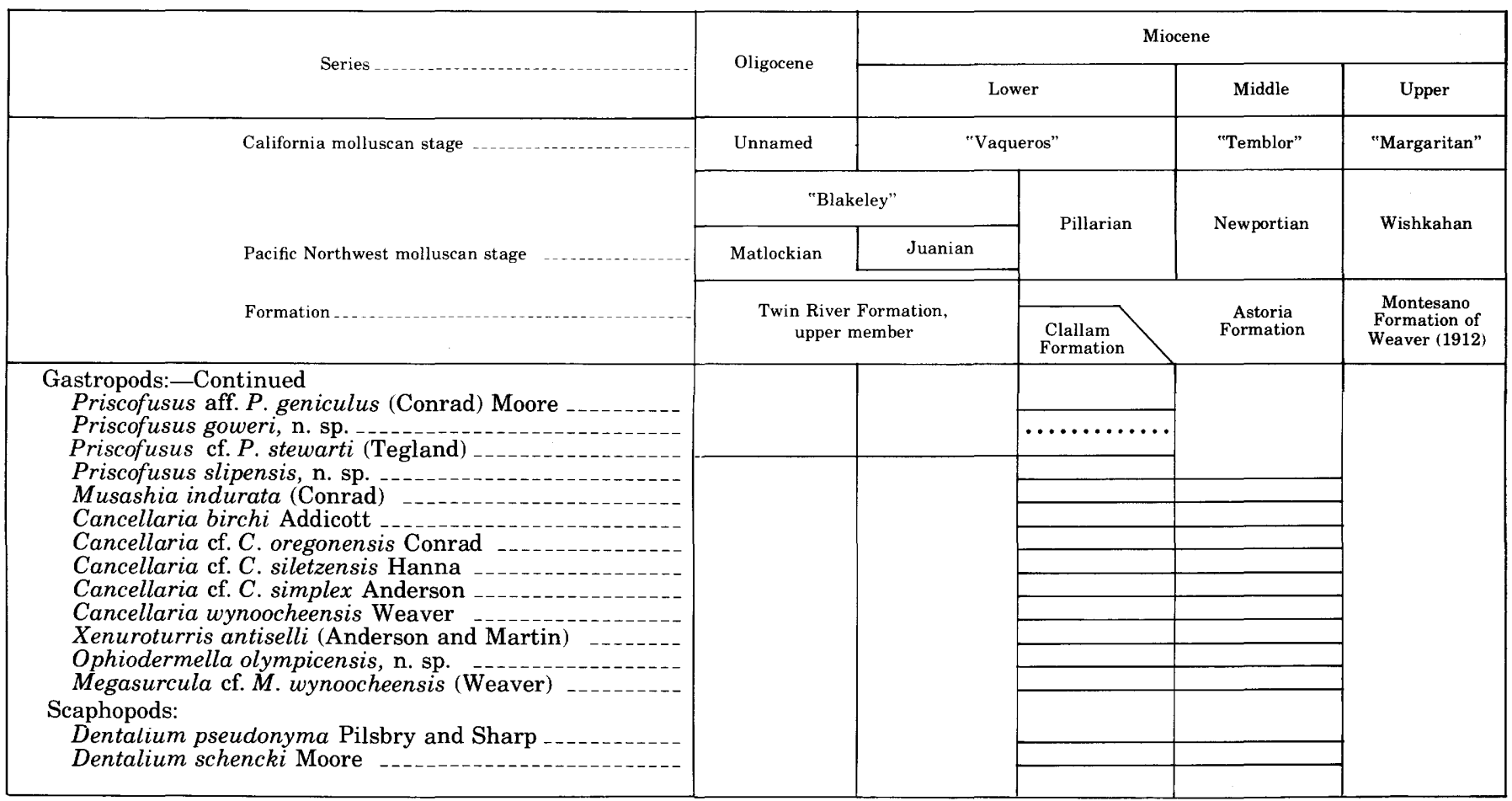

spread species restricted to the provincial middle Miocene. Data presented by Moore (1963, table 2) show that these two taxa have virtually exclusive stratigraphic distributions in the Newport Embayment. Occurrences of $V$. fucanus are in strata mapped as Nye Mudstone (Snavely and others, 1969; 1976) whereas those of Patinopecten are in the stratigraphically higher Astoria Formation. At or near the Nye-Astoria contact, however, Moore (1963, table 2, loc. 181) does report the two taxa from the same locality. This cooccurrence is believed to be the transitional overlap between the two species. The co-occurrence of these genera in an old collection from Astoria, Oreg. (Moore, 1963 , table 2 , loc. 1a), may represent the same situation. It is also possible that this collection includes material from a substantial stratigraphic intervalboth the early and middle parts of the section there-

TABLE 4.-Specifically identified mollusks from the Clallam Formation that are not known to occur in other formations

\section{Gastropods:}

Semicassis pyshtensis, n. sp.

Trophosycon clallamensis (Weaver)

Molopophorus n. sp. aff. M. newcombei (Merriam)

Priscofusus goweri, n. sp.

Pelecypods:

Anadara aff. A. lakei (Wiedey)

Modiolus n. sp.? aff. $M$. restorationensis Van Winkle

Macoma n. sp. aff. M. secta (Conrad) as the older collections from the Pacific coast commonly do.

The uniquely orbicular species Macoma n. sp. Moore (1963) also occurs in the Nye Mudstone and the Clallam Formation. This distribution complements the provincial early Miocene distributions of Mytilus n. sp. and Vertipecten fucanus.

Three gastropods are especially suggestive of provincial early Miocene age. Ancistrolepis rearensis has

TABLE 5.-Mollusks characteristic of the Clallam Formation (species that are identified, without doubt, from at least six collections)

[Species marked with an asterisk (*) also occur in the provincial middle Miocene fauna of the Astoria Formation and, so far as is known, are restricted to the lower Miocene Pillarian Stage and middle Miocene Newportian Stage]

Gastropods:

*Trochita n. sp.

* Bruclarkia yaquinana (Anderson and Martin)

*Ophiodermella olympicensis, n. sp.

Pelecypods:

*Nuculana calkinsi (Moore)

Vertipecten fucanus (Dall)

*Cyclocardia subtenta (Conrad)

Spisula albaria (Conrad)

Tellina emacerata Conrad

*Macoma albaria Conrad

*Katherinella angustifrons (Conrad)

* Securella ensifera (Dall)

Thracia trapezoides (Conrad)

Scaphopod:

*Dentalium schencki Moore 
been previously recorded only from the late Oligocene and early Miocene "Blakeley" Stage [=Matlockian Stage of Armentrout, 1975]. Priscofusus aff. $P$. geniculus (Conrad) Moore is restricted to exposures of the Nye Mudstone in coastal Oregon (as mapped by Snavely and others, 1976) and is bracketed, stratigraphically, by occurrences of Vertipecten fucanus (Dall) (Moore, 1963, table 2). Its occurrence stratigraphically below the Patinopecten propatulus assemblages of the middle Miocene Astoria Formation is likewise suggestive of provincial early Miocene age. Molopophorus n. sp. aff. $M$. newcombei seems to form a phylogenetic link between the early middle Miocene $M$. matthewi Etherington and the early Miocene species $M$. newcombei. It is suggestive, therefore, of a provincial late early Miocene age. Another gastropod that is doubtfully identified because of poor preservation, Priscofusus cf. P. stewarti, may be identical to a species known only from the provincial early Miocene of the Pacific Northwest.

Long-range correlation with central and southern California based on benthonic foraminifers (Rau, 1964) substantiates a late early Miocene provincial age for the basal part of the Clallam Formation in terms of the California sequence. The boundary between the Zemorrian and Saucesian stages is at, or very close to, the contact between the Twin River Formation and the overlying Clallam Formation (Rau, 1964); the basal part of the Clallam is presumably of early Saucesian age inasmuch as there is no indication of a depositional hiatus between the two formations (fig. 3 and Gower, 1960). This microfaunal boundary, as discussed by Addicott $(1973,1974)$, falls within the lower Miocene "Vaqueros" Stage of the California provincial megainvertebrate chronology; in California the lower part of the Saucesian Stage is equivalent to the upper part of the "Vaqueros" Stage. The "Vaqueros" Stage is based on tropical and subtropical species restricted to California and more southerly latitudes during the early Miocene. In the Pacific Northwest, the early Miocene is represented by the cooler water molluscan assemblages of the Juanian Stage [=upper part of the "Blakeley" or Matlockian Stage] and the overlying fauna of the Pillarian Stage, represented by the Clallam Formation and the Nye Mudstone.

Although the discrepancy between mollusks and foraminifers in provincial age classification of the Clallam Formation-early Miocene versus middle Miocene-has long been apparent, it seems to have been disregarded, perhaps because of the reported unconformity at the base of the Clallam and the alleged erosion of more than $600 \mathrm{~m}$ of the upper member of the Twin River Formation (Weaver, 1937, p. 175; Weaver and others, 1944). This supposed unconformity has been regarded, at least by some specialists (Weaver and others, 1944), as representing the missing early Miocene "Vaqueros" Stage. It is shown by Durham (1944, fig. 7) as a faunal hiatus between the two formations. In actuality, data considered here show that assemblages from the basal part of the Clallam are coeval with the fauna of the early Miocene "Vaqueros" Stage of California as are those from the uppermost part of the Twin River Formation (Addicott, 1967). These assemblages are not, as previously maintained (Durham, 1944; Addicott, 1969), coeval with the middle Miocene fauna of the "Temblor" Stage. There is, therefore, no faunal disconformity or hiatus between the two formations as is clearly implied by the conformable and gradational lithologic contact first reported by Gower (1960).

Correlation of the Clallam Formation with other key sequences on the Pacific coast is shown in figure 10. Of note is the evidence for assignment of the Astoria Formation of the Newport Embayment, Oreg., to the provincial middle Miocene. Howe (1926), Moore (1963), and Addicott (in Snavely and others, 1964) have correlated the Astoria molluscan fauna with the middle Miocene "Temblor" Stage of California. Foraminiferal studies support this correlation. Rau (in Snavely and others, 1964) has shown that benthonic foraminifers from the Astoria Formation and the Nye Mudstone which unconformably underlies the Astoria Formation in the Newport Embayment are of Saucesian age. The Astoria can be referred to the upper part of the Saucesian Stage on the basis of the reported occurrence of upper Saucesian foraminifers in the upper part of the underlying Nye Mudstone by Heacock and Boyd (1954). According to Rau (in Snavely and others, 1964) it may also contain assemblages of Relizian age. Presumably most of the Nye Mudstone, including the localities from which distinctive pre-middle Miocene assemblages containing Vertipecten fucanus have been

TABLE 6.-Mollusks from the Clallam Formation suggestive of a provincial early Miocene age

\footnotetext{
Pelecypods:

Archarax dalli (Clark)

Macoma cf. M. twinensis Clark

Macoma n. sp. Moore

Mytilus n. sp. aff. M. tichanovitchi Makiyama

Spisula sookensis Clark and Arnold

Spisula cf. S. hannibali Clark and Arnold

Thracia cf. T. schencki Tegland

Vertipecten fucanus (Dall)

Gastropods:

Ancistrolepis rearensis (Clark)

Epitonium clallamense Durham

Molopophorus n. sp. aff. M. newcombei (Merriam)

Priscofusus aff. $P$. geniculus (Conrad) Moore

Priscofusus cf. P. stewarti (Tegland)
} 


\begin{tabular}{|c|c|c|c|c|c|c|c|}
\hline $\begin{array}{l}\text { Provincial } \\
\text { series }\end{array}$ & $\begin{array}{l}\text { Benthonic } \\
\text { foraminiferal } \\
\text { stage } \\
\text { (Kleinpell, 1938) }\end{array}$ & $\begin{array}{c}\text { California } \\
\text { molluscan } \\
\text { stage } \\
\text { (Weaver and others, } \\
\text { 1944; Addicott, 1972) }\end{array}$ & $\begin{array}{l}\text { Pacific Northwest } \\
\text { molluscan } \\
\text { stage } \\
\text { (Addicott, 1976) }\end{array}$ & $\begin{array}{l}\text { Northern } \\
\text { Olympic Mountains } \\
\text { Washington } \\
\text { (This report) }\end{array}$ & $\begin{array}{l}\text { Southwestern } \\
\text { Washington } \\
\text { (Wolfe and McKee, 1972; } \\
\text { Rau, 1967) }\end{array}$ & $\begin{array}{c}\text { Newport Embayment, } \\
\text { Oregon } \\
\text { (Snavely and others, } \\
\text { 1969a, 1974) }\end{array}$ & $\begin{array}{c}\text { Gulf of Alaska } \\
\text { Yakataga District } \\
\text { (Kanno, 1971; Miller, } \\
\text { 1971) }\end{array}$ \\
\hline $\begin{array}{l}\text { Middle } \\
\text { Miocene }\end{array}$ & $\begin{array}{l}\text { Luisian(?) and } \\
\text { Relizian }\end{array}$ & "Temblor" & Newportian & & & $\begin{array}{l}\text { Astoria } \\
\text { Formation }\end{array}$ & $\begin{array}{l}\text { Yakataga } \\
\text { Formation }\end{array}$ \\
\hline \multirow{2}{*}{$\begin{array}{l}\text { Lower } \\
\text { Miocene }\end{array}$} & & \multirow{2}{*}{ "Vaqueros" } & Pillarian & $\begin{array}{l}\text { Clallam } \\
\text { Formation }\end{array}$ & & $\begin{array}{c}\text { Nye } \\
\text { Mudstone }\end{array}$ & \multirow{3}{*}{$\begin{array}{l}\text { Upper part of } \\
\text { Poul.Creek } \\
\text { Formation }\end{array}$} \\
\hline & \multirow[t]{2}{*}{ Zemorrian } & & Juanian & \multirow{2}{*}{$\begin{array}{l}\text { Upper member of } \\
\text { Twin River } \\
\text { Formation }\end{array}$} & \multirow{2}{*}{$\begin{array}{l}\text { Upper part of } \\
\text { Lincoln Creek } \\
\text { Formation }\end{array}$} & $\begin{array}{l}\text { Yaquina } \\
\text { Formation }\end{array}$ & \\
\hline $\begin{array}{c}\text { Upper } \\
\text { Oligocene }\end{array}$ & & Unnamed & $\begin{array}{l}\text { Matlockian or } \\
\text { "Blakeley" }\end{array}$ & & & $\begin{array}{c}\text { Upper part of } \\
\text { Alsea Formation }\end{array}$ & \\
\hline
\end{tabular}

Figure 10.-Correlation of the Clallam Formation with other sequences in the Pacific Northwest States and the provincial marine chronologies.

collected, are of early Saucesian age. Elsewhere in Oregon and in southwestern Washington (fig. 10) the lower part of the Astoria Formation is of provincial early Miocene age.

The fauna of the Clallam Formation may be coeval with molluscan assemblages from the upper part of the Poul Creek Formation at the head of the Gulf of Alaska. The percentage of species in common with the Poul Creek is small (Kanno, 1971, table 4), perhaps because of the much cooler water aspect of the Alaskan early Miocene fauna. Collections from the uppermost $200 \mathrm{~m}$ of the Poul Creek Formation in a measured section at Cape Yakataga (Kanno, 1971) contain meager assemblages with few stratigraphically distinctive species. One of these, however, Ancistrolepis rearensis (Clark), is restricted to the lower Miocene of northwestern Washington. Two mollusks that are restricted to the Pillarian Stage represented by the Clallam Formation and its molluscan fauna do occur in the upper part of the Poul Creek, but their stratigraphic position within that interval is not known. These species are Vertipecten fucanus [V. sp. Kanno (1971)] and Epitonium clallamense Durham. Mollusks that do not range into post-early Miocene strata in Oregon and Washington and correlative strata in California, Aturia, Musashia weaveri (Tegland), Thracia schencki Tegland, and Acila gettysburgensis (Reagan), also occur in the upper part of the Poul Creek Formation (Kanno, 1971; MacNeil, in Miller, 1971). Elsewhere in the lower and upper parts of the Poul Creek, Liracassis apta (Tegland), a species restricted to the Juanian Stage-the lower part of the lower Miocene of Oregon and Washington, has been recorded from several localities (see Kanno, 1971).

Close to two-thirds of the mollusks from the Clallam also occur in the middle Miocene part of the Astoria Formation-the Newportian Stage-or are represented by closely allied, possibly conspecific, taxa (table 3). Several Clallam species, however, are restricted to formations of provincial early Miocene age in addition to many others whose concurrent stratigraphic ranges, or position in an inferred evolutionary sequence, are indicative of a pre-middle Miocene age. The strong similarity between the late early Miocene (Pillarian) fauna of the Clallam and the younger middle Miocene (Newportian) fauna of the Astoria Formation is not unique among middle latitude early and middle Miocene faunas of the eastern North Pacific. The faunas of the lower Miocene "Vaqueros" and the middle Miocene "Temblor" Stages of California also have many species in common. Consequently, differentiation between these California stages is difficult. In comparison with middle Miocene faunas, the early Miocene faunas of both the "Vaqueros" and the Clallam Formation are characterized by a much lower level of taxonomic diversity. This relation further complicates recognition and differentiation of provincial early Miocene faunal assemblages.

In summary, reevaluation of the provincial age of the Clallam Formation, based principally on new 
faunal data and further anälysis of the stratigraphic ranges of key species in other Pacific coast sequences, suggests that the molluscan assemblages of the Clallam Formation are of early Miocene rather than middle Miocene provincial age. They represent the later part of the provincial early Miocene and are readily separable from the fauna of the Juanian Stage and the coordinate upper parts of the "Blakeley" and Matlockian Stages [Echinophoria apta Zone of Durham (1944)]. They form the faunal basis for the recently named Pillarian Stage (Addicott, 1976). Benthonic foraminiferal correlations with the provincial microfaunal standard sections in California (Kleinpell, 1938; Rau, 1964) support this reassignment.

\section{PILLARIAN STAGE}

The Clallam Formation has been designated the type section for the Pillarian Stage (Addicott, 1976). This stage, which represents the upper part of the lower Miocene of Oregon and Washington (fig. 10), is represented by the fauna of the Nye Mudstone of the Newport Embayment, the lower part of the Astoria Formation in the type area near Astoria, Oreg., and in the Grays River quadrangle and possibly other areas in southwestern Washington, and the Hoh rock assemblage (Rau, 1973) of the western margin of the Olympic Mountains, Wash. The Pillarian is equivalent to the upper part of the so-called Vaqueros Stage (see Addicott, 1972) of the California Coast Ranges.

\section{PALEOECOLOGY}

\section{BATHYMETRY}

All the molluscan assemblages from the Clallam Formation represent inner sublittoral depths (less than $100 \mathrm{~m}$ ). Qualitative analysis of assemblages from the tectonically undisturbed sections in the lower part of the Clallam Formation (fig. 8) points to a gradual shallowing of the depositional environment. This trend is an extension of the shallowing of depositional environments in the upper part of the Twin River Formation indicated by benthonic foraminiferal assemblages (Rau, 1964). This shoaling is the concluding phase of an Eocene to Miocene depositional cycle in which maximum deepening took place during the Oligocene. Elsewhere in western Washington the concluding phase of the transgressive-regressive cycle is represented by the middle Miocene part of the Astoria Formation (Rau, 1967, p. 25; Wagner, 1967).

The stratigraphically lowest assemblage from the Clallam (loc. M6375) consists of a few taxa suggestive of deposition in the middle part of the sublittoral zone. Most of these species also occur in the much larger, and more environmentally definitive, collections from a 7-m interval nearly $60 \mathrm{~m}$ above the base of the Clallam (locs. M4050 and M5879). Modern depth ranges of genera and species composing this assemblage suggest deposition in the middle to lower parts of the inner sublittoral zone-possibly 50-75 m. Species composing this assemblage occur as isolated individuals, presumably in place. The bivalves are articulated. The assemblage is moderately large for the Clallam-25 species-but considerably smaller than a stratigraphically higher assemblage of current or storm wave deposited mollusks that occurs about $130 \mathrm{~m}$ stratigraphically higher in the section (loc. M4049).

The basal assemblage from the Clallam contains a few living species of moderately deep inner sublittoral aspect: Conchocele disjuncta Gabb, Panopea abrupta (Conrad), and Thracia trapezoides (Conrad). Available data on the depth ranges of these species in the modern eastern North Pacific indicate an overlap in the interval between 18 and $75 \mathrm{~m}$ (Kanno, 1970; unpub. data from Rae Baxter [Thracia] and Lynn Glover [Panopea]). Other mollusks characteristic of moderate depths in the sublittoral zone, but that extend downward well into the bathyal zone, include Archarax, Lucinoma, Solamen, and Musashia. Collectively, these mollusks suggest that water depths were in the lower part of the interval indicated by living speciesprobably no shallower than $50-75 \mathrm{~m}$. Archarax lives at depths greater than about $110 \mathrm{~m}$ off the eastern North Pacific coast today. Musashia is locally extinct but is represented by species that live at depths of $100 \mathrm{~m}$ or greater off the coast of Japan (Habe, 1964). The other genera are suggestive of somewhat shallower water conditions in terms of their known depth ranges. Solamen ranges from about $30 \mathrm{~m}$ into the upper bathyal zone (Soot-Ryen, 1955) along the Pacific coast, and Lucinoma annulata (Reeve), a homologue of the Oligocene and Miocene species L. acutilineata, ranges from about $15 \mathrm{~m}$ (Smith and Gordon, 1948) to bathyal depths (Parker, 1963) in the eastern North Pacific.

The outer sublittoral environment suggested by modern bathymetric data for Musashia and Archarax seems anomalously deep for this assemblage in that many of the other mollusks are of inner sublittoral aspect. For this reason, it is inferred that during the early Miocene these two genera were living at somewhat shallower depths than they are now found and that they were not restricted, as indicated by their modern bathymetric occurrences, to the outer part of the sublittoral zone or greater depths.

A somewhat higher assemblage from the east flank of the anticline near Slip Point (loc. M4414) records shallowing to depths in the middle to upper part of the inner sublittoral zone. Most of the species in it also occur in the collections from the lowest $55 \mathrm{~m}$ of the 
Clallam, but there are none of the deeper water indicators. Among the mollusks not found in stratigraphically lower collections, Mytilus n. sp. aff. $M$. tichanovitchi Makiyama is probably the most significant bathymetric index. Mytilus is characteristic of shallow inner sublittoral to intertidal depths along the eastern North Pacific coast today. It is of fairly common occurrence in this and other localities in the lower $300 \mathrm{~m}$ of the Clallam, but does not occur in the lowest $55 \mathrm{~m}$ of the formation. The appearance of Dosinia is also suggestive of shallower water conditions as well as probable increase in marine water temperature in terms of its modern distribution in the eastern North Pacific (Keen, 1971).

By far the largest assemblage (locs. M4049 and M5878) in the lower part of the Clallam Formation is from intertidal zone exposures on the west flank of the anticline near Pillar Point about $190-210 \mathrm{~m}$ above the base of the formation (fig. 8). Fossils in this assemblage occur as layered concentrations whereas stratigraphically lower fossils occur as isolated individuals, apparently in place. The larger size of the assemblage from localities M4049 and M5878 may well be due to the mode of formation as current or storm wave concentrations; the assemblage may include specimens from more than one community.

The size of the assemblage from localities M4049 and M5878 permits qualitative comparison with the moderately large assemblage from near the base of the Clallam (loc. M4050). It is interesting to note that none of the deeper sublittoral genera and species from the lowest assemblage (M4050) reappear in this one, particularly in view of the fact that this assemblage may include representatives from more than one biotope. There are several mollusks that do not occur in stratigraphically lower collections. And these are suggestive of inner sublittoral depths appreciably shallower than near the base of the Clallam-possibly from about 15 to $35 \mathrm{~m}$. Shallow inner sublittoral depths are suggested by the occurrence of Clinocardium n. sp. aff. C. nuttalli, Yoldia supramontereyensis, and the abundance and diversity of mactrids comparable to species living at depths of less than $35 \mathrm{~m}$ along the Pacific coast (Smith and Gordon, 1948; Quayle, 1973). An upper limit of about 15 to $20 \mathrm{~m}$ for the large assemblage from M4049 and M5878 is indicated by mollusks that are either still living today or are closely related and perhaps ancestral to living species: Thracia trapezoides, Lucinoma acutilineata [L. annulata], Megasurcula cf. M. wynoocheensis [Megasurcula spp.], and Macoma cf. $M$. astori $[M$. brota $]$.

A smaller assemblage from about $110 \mathrm{~m}$ above the base of the Clallam (loc. M4681 and NP163) does not differ significantly in taxonomic composition from
M4049. It consists mostly of bivalves suggestive of shallow inner sublittoral depths comparable to the 15to 35-m range inferred for locality M4049.

The collection believed to be from near the top of the Clallam Formation (loc. M4678), on the basis of its location near the center of the synclinal structure between Pillar Point and Slip Point (see Gower, 1960), has only three mollusks that are not recorded from stratigraphically lower assemblages. One of these, a tellinid resembling the modern species Macoma secta which is an intertidal and upper inner sublittoral species (Coan, 1971), may be of bathymetric significance. However, the only suggestion that this part of the section may be of appreciably shallower bathymetric facies than the lowest part of the Clallam comes from faunal data of Arnold and Hannibal (1913). They list a species of Anadara as the sole mollusk from a locality (NP162) at the Clallam coal mine which is within a few hundred metres, geographically, of locality M4683, and presumably at, or near the top of, the Clallam Formation. The occurrence of this bivalve, without any other mollusks, may be indicative of extremely shallow water, possibly intertidal, conditions inasmuch as Anadara in the northern part of its modern geographic distribution off Mexico today is characteristic of low taxonomic diversity assemblages from lagoonal and mangrove swamp environments (Parker, 1963; Keen, 1971).

\section{PALEOCLIMATE}

Most of the still-living molluscan genera from the Clallam Formation are found today in temperate middle latitudes along the Pacific coast. None of the genera are restricted to cooler, more northern latitudes, but a few are found living in warm temperate to subtropical latitudes far to the south of western Washington. The appreciable representation of warm-water taxa in the Clallam assemblages suggests that water temperatures were significantly warmer at this latitude than they are today. The warm-water gastropods are Trochita, Natica, Neverita, Ficus, Semicassis, and Cancellaria. Some species of Cancellaria are referable to the warm-water subgenus Euclia (Addicott, 1970a). Only two of the pelecypods are of warm-water aspectAnadara and Dosinia. Both of these may have lived in cooler water assemblages during the middle and late Tertiary than they are found in today (Addicott, 1970b; Stanton and Dodd, 1970; Kern, 1973). By and large all of these warm-water taxa are limited to only one or two assemblages, and within these assemblages they are of relatively rare occurrence. This kind of occurrence suggests that they were not particularly characteristic of the Clallam assemblages and introduces the possibility of seasonal recruitment from warmer water 
populations living to the south of the fossil localities (Addicott, 1966a, p. 14-15; Zinsmeister, 1974).

It seems doubtful that temperatures were as warm as would be indicated by a strict application of modern occurrences of the tropical to subtropical genera Trochita, Cancellaria (Euclia), Ficus, Dosinia, and Anadara s.s. that have their northernmost latitudinal occurrences in, or close to, the modern Surian molluscan province (Valentine, 1966) today, a biographic unit situated off the west coast of southern Baja California, Mexico. Strict uniformitarian interpretation seems especially inappropriate because two of these taxa seem to have changed their temperature tolerance since the middle or late Tertiary during which time they occurred with relatively cooler water assemblages. Moreover, the apparent lack of large populations of these warm-water genera suggests possible seasonal recruitment from warmer, more southern latitudes. Nevertheless, this element of distinctly warm-water taxa does argue for at least cycles of water temperature appreciably warmer than occur at this latitude today and, there are no data suggesting cooler water conditions.

In view of the reclassification of the age of the Clallam fauna from provincial middle Miocene to late early Miocene, the paleoclimatic diagram for the middle and late Tertiary of northwestern Washington (Addicott, 1969) needs to be modified so as to position the Clallam data in the uppermost part of the "Vaqueros" Stage rather than in the overlying "Temblor" Stage. This change remains consistent with the inferred early Oligocene to middle Miocene warming trend in the middle latitudes of the eastern North Pacific (Addicott, 1969). Although the faunas of the Sooke and the Clallam Formations are now believed to be of early Miocene age, they are not coeval. The apparent warming that occurred from the time of deposition of the Sooke to the time of deposition of the Clallam is merely condensed into a shorter period.

Neither the warm-temperate aspect of the molluscan assemblages inferred from modern distributions of component genera nor the apparent warming of the shallow inner sublittoral marine environment during the early Miocene seem to be indicated by benthonic foraminiferal assemblages. Rau (1964) infers continuing cool-water conditions during the progressive shallowing of the bathymetric environment that took place during deposition of the upper member of the Twin River and the overlying Clallam Formation. The different interpretations based on the two kinds of benthic organisms seems perplexing, but it may be no more than an indication of a very shallow thermocline below which water temperature remained fairly constant but above which shallow inner sublittoral waters become progressively warmer during the late Oligocene and early Miocene.

\section{MOLLUSCAN PALEONTOLOGY}

The molluscan fauna of the Clallam Formation consists of 76 taxa identified from collections made by the writer and from fairly extensive Stanford University collections made by Harold Hannibal (Arnold and Hannibal, 1913) more than 60 years ago. Conventional systematic description of these mollusks is dispensed with in favor of taxonomic notes indicating significant morphologic features that either typify a taxon or distinguish it from similar species. Many of the taxa have been treated in Moore's (1963) monograph of the Astoria Formation of Oregon. Others were considered in a study of the California early and middle Miocene by Addicott (1970a). Where pertinent, synonyms not considered in Moore (1963) or Durham (1944) are noted and discussed. Original descriptions of previously named taxa identified here are referenced in the taxonomic notes.

Newly described species and other species that appear to be undescribed but that are represented by material inadequate for formal description are treated more thoroughly (table 7).

Practically all the mollusks from localities in the Clallam Formation are illustrated. Also illustrated are some of Reagan's (1909) specimens (table 1) from the Clallam that were originally figured by line drawings, most of which are crudely drawn and extremely difficult to relate to actual fossil material.

The systematic flow is patterned after the familial classification of gastropods by Taylor and Sohl (1962) and of bivalves by McCormick and Moore (1969) that is based on the earlier classification of Newell (1965). The check list of species from the Clallam Formation (table 2 ) is arranged in the same sequence and may be used

TABLE 7.-New species of mollusks described here and other species believed to be new but represented by material that is inadequate for formal description

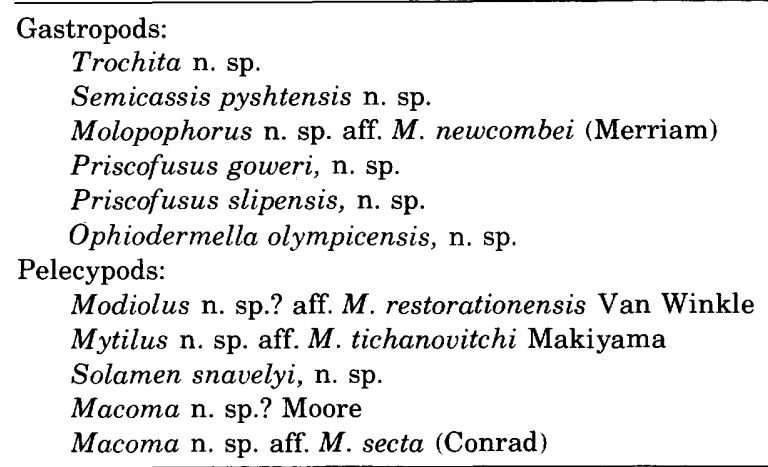


as a generalized index for locating taxonomic notes in this section.

\section{GASTROPODS TURRTTELLIDAE}

Turritella oregonensis (Conrad, 1849) [pl. 1, figs. 10, 11, 17]. Specimens of this small Turritella occur in localities near the top of a measured section on the west flank of the anticline near Pillar Point. They have a pair of strong primary spirals in the anterior part of the whorls and a single strong primary spiral rib in the posterior part (pl. 1, figs. 11, 17). This sculptural pattern is different from other figured specimens of this species (Merriam, 1941, pl. 20, figs. 17, 19, 20; Moore, 1963, pl. 1, figs. 9-12; Addicott, 1970a, pl. 2, fig. 15), all of which have clearly differentiated pairs of primary and secondary spiral ribs. Nevertheless, Moore (1963, p. 25) states that "Above the paired spirals may be 1 or occasionally 2 secondary spirals" indicating that three rather than four ribs may be the more common pattern. Accordingly, the Clallam specimens are identified as $T$. oregonensis rather than as a new species.

In the Newport Embayment of northwestern Oregon, Turritella oregonensis occurs in the upper part of the Nye Mudstone (USGS loc. 15965) and in the Astoria Formation. These are indicative of an early to middle Miocene provincial range.

\section{EPITONIIDAE}

Epitonium clallamense Durham (1937) [pl. 1, figs. 8, 13]. Specimens from locality M4413 near Slip Point have 9 axial ribs, falling within the range of 8 to 10 ribs described by Durham (1937, p. 491, pl. 56, figs. 27, 28 ). The types of this species are from the east end of Clallam Bay (Addicott, 1970a, p. 74), presumably from the lower part of the Clallam Formation because reconnaissance study of this area indicates that strata referable to the Clallam are exposed during the lowest seasonal tides. This species also occurs in an old collection from exposures immediately east of Slip Point (SU loc. NP89), very close to the broadly defined type locality. This species is restricted to the Clallam Formation in northwestern Washington. It occurs in the presumably coeval faunas of the Jewett Sand in central California (Addicott, 1970a) and the upper part of the Poul Creek Formation of the Gulf of Alaska (Kanno, 1971). Its earliest occurrence is in the lower Miocene Sooke Formation of Vancouver Island (Addicott, 1970a) and not in probable middle Oligocene strata as initially reported (Durham, 1937, p. 491).

\section{CALYPTRAEIDAE}

Trochita n. sp. [pl. 1, figs. 9, 12, 18]. One of the most commonly occurring gastropods in the Clallam Forma- tion is a moderately coarse ribbed calyptraeid (pl. 1, figs. 12,18 ) that is conspecific with a poorly known taxon from the Astoria Formation of Oregon, Trochita? n. sp.? Moore (1963, p. 26, pl. 1, fig. 23). In profile, specimens vary from nearly smooth to slightly shouldered. This is clearly an undescribed species but the specimens from the Clallam and the known specimens from coastal Oregon (Moore, 1963) and southwestern Washington (Wolfe and McKee, 1972) are too poorly preserved to adequately determine surficial sculpture and permit formal description. Trochita n. sp. resembles, somewhat, the modern tropical eastern Pacific species T. spirata (Forbes) and T. trochiformis (Born). Trochita $\mathrm{n}$. sp. is much flatter and, although all available specimens are decorticated to varying degrees, the spiral sculpture is much more subdued. An early Miocene species T. sookensis (Clark and Arnold, 1923, p. 168, pl. 36, figs. 1 and 2) from the southwestern coast of Vancouver Island is distinguished from Trochita $n$. sp. by its finer and more numerous radiating ribs. The spire of $T$. sookensis species is of variable height; specimens from USGS locality M4060 are very low spired, comparable in this respect to Trochita n. sp. Another poorly preserved early Miocene species from California, Trochita cf. T. spirata (Forbes) (Addicott, 1970a, p. 61-62), has coarser spiral sculpture than Trochita n. sp. and is unusually strongly shouldered. The common Miocene and Pliocene species T. filosa (Gabb, 1866, p. 15, pl. 2, figs. 25, 25a) has extremely fine spiral ribs, at least three times as many as Trochita n. sp.

Crepidula praerupta Conrad (1849) [pl. 1, figs. 1, 22; pl. 2, fig. 24]. This species, occurring in several collections from the Clallam Formation, is externally similar to C. princeps Conrad, with which it occurs in the Clallam, but the internal septum is different. The external morphology of these two species is so variable, that it cannot always be used to distinguish them. On specimens of $C$. praerupta the insertions of the internal septum are approximately equidistant from the beak (pl. 1, fig. 1) whereas on C. princeps the edge of the septum defines a broadly open " $\mathrm{S}$ " and the insertions of the septum are at unequal distances from the beak (pl. 1, fig. 7). Crepidula praerupta ranges from the early Miocene (Loel and Corey, 1932; Kanno, 1971) to the late Miocene (Moore, 1963).

Crepidula princeps Conrad (1855) [pl. 1, figs. 6, 7]. A few deformed specimens of this moderately large Crepidula occur in the Clallam. The strongly curved septal margin of this species (pl. 1, fig. 7) is one of the most distinctive specific characters. Crepidula princeps ranges from the early Miocene to the Pleistocene along the Pacific coast (Addicott, 1970a, p. 64). This is the first record of $C$. princeps from the Pacific Northwest 
States. A moderately large, suborbicular Crepidula from the Sooke Formation of southwestern Vancouver Island, British Columbia, Canada (USGS loc. M4060), has the same septal configuration as $C$. princeps; it may represent this species, but the weakly inflated, suborbicular shell and the blunt apex suggest that it is a distinct species, possibly $C$. sookensis Clark and Arnold.

Crepidula rostralis (Conrad, 1865) [pl. 2, figs. 23, 25]. The Clallam record of this species constitutes another range extension; it was previously known only from provincial middle Miocene strata (Addicott, 1970a). The illustrated specimen is deformed, as are most of the specimens of Crepidula from the Clallam. It is slender and elongate during the early stages of growth; the flattening is inferred to have been caused by subsequent deformation. This specimen has the pointed beak overhanging, or extending beyond, the aperture; this beak is characteristic of $C$. rostralis and enables this species to be readily differentiated from other species.

Crepidula sp. [pl. 1, fig. 23]. A small Crepidula with an orbicular aperture and a very high, more or less vertically oriented beak. It seems to be distinct from other species in the Clallam Formation. The septal insertions are almost opposite each other. Since this is a very small, presumably immature, specimen, it could be an aberrant form of one of the other Clallam species-C. praerupta - which has similar septal insertions.

\section{NATICIDAE}

Natica cf. $N$. clarki Etherington (1931) [pl. 1, figs. 19, $27,28]$. A few small naticids from the Clallam resemble the early and middle Miocene species $N$. clarki Etherington (1931, p. 93, pl. 12, fig. 12). These specimens have a well-developed, fairly broad umbilical callus that is unlike the callus on the holotype but comparable to the calluses of other specimens included in this species by Marincovich (1973, p. 235-236).

Natica vokesi Addicott (1966b) [pl. 1, figs. 14-16]. This is the most common naticid in the Clallam. Specimens have a slender umbilical callus reflecting a broad, but indistinct, funicular rib comparable to type material from Oregon (Addicott, 1966b, p. 638-639, pl. 77 , figs. 2-5). Many of the large, undetermined naticids from localities in the Clallam probably are this species, but the preservation is too poor to permit specific identification.

Neverita jamesae Moore (1963) [pl. 1, figs. 4, 5, 20, 24]. A poorly preserved specimen (pl. 1, fig. 24) from USGS loc. M4684 has the widely open umbilicus, small bilobed callus, and broad apical angle characteristic of this species (Moore, 1963, p. 28-29, pl. 2, figs. 5, 15, 19).
This species was identified by Arnold and Hannibal (1913, p. 588, loc. NP161) as "Polinices saxea Conrad." $P$. saxea Conrad is a doubtful species that cannot be recognized because the type material is lost and the original description and illustration are vague (Moore, 1963, p. 28).

Polinices victorianus Clark and Arnold (1923) [pl. 1, fig. 25]. This early to middle Miocene species is known from only two localities in the Clallam. It is characterized by a narrow umbilical opening with a distinct, somewhat enlarged umbilical callus (Clark and Arnold, 1923, p. 170, pl. 33, figs. 1 and 5). As is the case with the other Clallam naticids, it may be represented by poorly preserved, specifically indeterminate material in other Clallam collections.

Sinum scopulosum (Conrad, 1849) [pl. 1, figs. 21, 26]. Specimens of this long-ranging naticid are generally preserved as internal molds. Often the fine spiral sculpture is imprinted on these steinkerns (pl. 1, fig. 21).

\section{CASSIDIDAE \\ Semicassis pyshtensis, n. sp.}

Plate 1, figures 2, 3

This fairly well-preserved cassidid has a low spire consisting of about four whorls; the penultimate whorl has prominent protractive axial ribs that are stronger than the straplike spiral ribs. These axial ribs are very subdued on the body whorl tending to be replaced by very faint irregular lines of growth. Spiral sculpture on the body whorl consists of 15 straplike ribs that are strongest toward the base. These are separated by fine secondary spirals. The face of the body whorl immediately adjacent to the aperture was covered by an apparently thin callus, a part of which is preserved on the fossa and on the base of the whorl.

The holotype (USNM 215928) is from USGS locality M4414. It is $42 \mathrm{~mm}$ high and $28 \mathrm{~mm}$ wide.

Semicassis pyshtensis differs from other middle and late Tertiary species from Oregon and Washington principally by its unique rib count. It is most similar to S. aequisulcatum (Dall, 1909, p. 63-64, pl. 5, figs. 1, 4), a late Miocene species from Oregon and southwestern Washington but differs from S. aequisulcatum in having 15 rather than 19 spirals. S. pyshtensis seems to form an evolutionary link between this finely sculptured late Tertiary species and the coarsely ribbed Oligocene species $S$. iani (Schenck, 1926, p. 80, pl. 13, figs. 8-11) which has only 11 spiral bands on the body whorl.

$S$. aequisulcatum and $S$. iani were previously assigned to Phalium (Schenck, 1926, Weaver, 1942). Morphologically they are much closer to species of 
Semicassis from Japan. The Japanese species have a very thin parietal callus that is smooth except for spiral plaits near the base of the apertural margin (Habe, 1964 , p. $69-70$, pl. 21). The Japanese species are from the inner sublittoral zone, 10-100 m. Semicassis pyshtensis differs from the modern S. centiquadrata (Valenciennes), a very shallow water species from the Panamic molluscan province (Keen, 1971, p. 501, fig. 949), in lacking a granulated or pustulose callus surface.

\section{FICIDAE}

Ficus modesta (Conrad, 1848) [pl. 1 figs. 29, 30]. This bulbous, finely sculptured species is definitely known from only one of the collections studied during this investigation. Mature specimens reach a moderately large size and are smooth except for spiral sculpture of alternating fine and ultrafine ribs crossed by fine axial lines of growth. The intersection of these axial and spiral systems produces a finely reticulate network. The relatively smooth exterior of this species permits differentiation from the coarsely noded Trophosycon clallamensis (Weaver) (pl. 1, fig. 31) which also occurs in the Clallam Formation. Ficus modesta occurs in the middle Miocene part of the Astoria Formation of southwestern Washington (Etherington, 1931; Addicott in Wolfe and McKee, 1972) and coastal Oregon (Moore, 1963).

Trophosycon clallamensis (Weaver, 1912) [pl. 1, fig. 31 ; pl. 2, fig. 34]. A small specimen with an unusually broad body whorl and broad apical angle was collected from near Slip Point (USGS loc. M4051). It has two prominent rows of nodes and a few relatively strong spiral ribs. These features distinguish it from Ficus modesta which is doubtfully recorded from the same locality. Trophosycon clallamensis resembles the widespread early Miocene to Pliocene species T. kernianum (Cooper), but it differs from T. kernianum in having a broader body whorl and weak, vertically elongated nodes (Addicott, 1970a, p. 75).

\section{MURICIDAE}

Trophonopsis sp. [pl. 2, fig. 20]. An incomplete external mold of the body whorl of a minute gastropod from loc. M4677 near Slip Point has well-preserved sculpture characteristic of Trophonopsis. The body whorl is angulated a short distance below the suture, the somewhat sinuous axial ribs are bladelike, and there is a long anterior canal. This may be the earliest record of the muricid genus along the Pacific coast. The earliest previous record seems to be from the late Miocene of the Cuyama Valley area of the central California Coast Ranges (Eaton and others, 1941, pl. 2, fig. 4).

\section{NEPTUNEIDAE}

Ancistrolepis rearensis (Clark, 1932) [pl. 3, fig. 26]. Only one specimen of this neptuneid has been collected from the Clallam. This species is characterized by a rounded whorl profile and a subsutural spiral rib situated high on the body whorl. The presence of the subsutural spiral rib distinguishes it from the presumably ancestral Oligocene species, $A$. clarki Tegland (1932, p. 131, pl. 12, fig. 14) on which this rib is indistinct from the suture (Durham, 1944, p. 177). Ancistrolepis clarki teglandae Durham (1944, p. 177, pl. 17, fig. 2) was shown by Kanno (1971, p. 118-119, pl. 13, figs. 5, 9; pl. 14, figs. 4-6) to be a junior synonym of this species. The occurrence of $A$. rearensis in the Clallam constitutes a range extension from the early Miocene Echinophoria apta zone of Durham (1944) from which it was previously known in the conterminous United States. The occurrence in the upper part of the Poul Creek Formation presumably is coeval judging by the co-occurrence with the "E." apta (see Kanno, 1971).

Bruclarkia yaquinana (Anderson and Martin, 1914) [pl. 2, figs. 5, 7-9]. This species, the most commonly occurring of the two species of Bruclarkia in the Clallam Formation, is characterized by four, or sometimes five, coarsely noded spiral cords on the body whorl. The cords become progressively weaker toward the base of the whorl. The body whorl is bordered posteriorly by a well-developed subsutural collar on both small and large individuals. Specimens from near the base of the Clallam are identical to material from the lower Miocene of the San Joaquin basin in California (Addicott, 1970a, pl. 10, figs. 8, 12, 13). As recognized here, B. yaquinana is a small species. A large doubtfully identified internal mold (pl. 2, fig. 5) from the vicinity of Slip Point has very coarsely noded spiral cords similar to $B$. yaquinana but the cords are more widely spaced. Since the earlier ontogenetic stages of this specimen are not preserved, definitive comparison with B. yaquinana cannot be made.

Bruclarkia oregonensis (Conrad, 1848) [pl. 2, figs. 1-3]. This is a larger, more rounded species which differs from B. yaquinana, with which it sometimes occurs, in having uniformly finer spiral sculpture through all stages of growth. Nevertheless, differentiation of the two species is sometimes very difficult. Specimens from locality M4051, for example, seem to link these two species. A few of these specimens are clearly B. yaquinana (pl. 1, fig. 9). Other specimens seem to more closely resemble $B$. oregonensis (pl. 2, figs. $4,6,19$ ). Still others have intermediate sculptural characteristics. The observed stratigraphic relation between these two species in central California (Addicott, 1970 a, p. 91) is not so clearly evident in northwestern 
Washington. It is suggested in a general way, however, by the almost exclusive occurrence of $B$. oregonensis at the top of the formation and by the decided prevalence of specimens of $B$. yaquinana at, and near, the base.

Bruclarkia oregonensis is best represented by material from near the top of the Clallam Formation (loc. M4678). These specimens (pl. 2, figs. 1-3) are relatively large, are weakly sculptured, and have a poorly developed subsutural collar, if any at all. They are very similar to specimens from the Astoria Formation of southwestern Washington (Etherington, 1931, pl. 11, figs. $1,3,4,7$ ).

Molopophorus n. sp. aff. M. newcombei (Merriam, 1897) [pl. 2, fig. 16]. The external mold of a Molopophorus from the basal part of the Clallam near Pillar Point (loc. M5879) seems to be an undescribed species. It is most closely allied, morphologically, to $M$. newcombei (Merriam, 1897, p. 65), an early Miocene species from the Sooke Formation of nearby Vancouver Island, British Columbia. When compared with $M$. newcombei $(\mathrm{pl} .2$, figs. 10,11 ), the Clallam specimen has generally weaker sculpture with both fewer spiral and axial ribs. Besides being weaker and more widely spaced, the spiral ribs of $M$. n. sp. aff. $M$. newcombei (Merriam) are obsolete on the posterior quarter of the body whorl. This apparently new species differs from the middle Miocene species $M$. matthewi Etherington (1931, p. 97 , pl. 13 , figs. $3,6,8,9,13$ ) in having a sculptured body whorl and a well-developed subsutural collar. Molopophorus n. sp. may possibly provide an evolutionary link between the early Miocene $M$. newcombei and the middle Miocene $M$. matthewi. Molopophorus does not seem to be closely related to $M$. anglonana (Anderson, 1905, p. 205, pl. 16, figs. 74-76), an early and middle Miocene species characterized by a flat body whorl segment bordered by a noded subsutural collar and a noded basal angulation.

\section{FUSINIDAE}

Priscofusus aff. P. geniculus (Conrad) Moore (1963) [pl. 2, fig. 12]. Two deformed and incomplete fusinids from the lower part of the Clallam Formation appear to be conspecific with this undescribed species of Priscofusus from the Nye Mudstone (Snavely and others, $1969 \mathrm{~b}$, pl. 1) south of Newport, Oreg. The body whorl of this taxon is unusually strongly angulated, and it has a relatively long, gently inclined subsutural slope. Available specimens are too incomplete to permit formal description of this species, which appears to be restricted to the late early Miocene of the Pacific Northwest States.

\footnotetext{
Priscofusus goweri, n. sp.

Plate 2, figures $14,17,18,21$
}

Fairly abundant specimens of Priscofusus from localities on the west flank of the anticline near Pillar Point appear to be different from known species of this genus. These specimens are characterized by about 15 vertically oriented axial ribs that occupy the upper half of the body whorl. The axial ribs extend from suture to suture on the penultimate whorl. The body whorl carries about 20 fine spiral cords; secondaries are intercalated between the uppermost of these.

The holotype (USNM 215962) is from USGS locality M4049. It is $18 \mathrm{~mm}$ high and $8 \mathrm{~mm}$ wide. Paratypes (USNM 215960, 215961, 215963) from this locality range from 16 to $23 \mathrm{~mm}$ in height and from 8 to $12 \mathrm{~mm}$ in width.

This species is named in recognition of Howard Gower who completed the first detailed geologic mapping of the Clallam Formation (Gower, 1960).

This species seems closest morphologically to Priscofusus clarki Kanno (1971, p. 122-123, pl. 13, fig. 8, pl. 14 , figs. $8,9,15$ ) from Alaska and $P$. stewarti (Tegland, 1933, p. 129-130, pl. 12, figs. 4-8) from Washington. The holotype of P. clarki (Kanno, 1971, pl. 3, fig. 8), the only well-preserved specimen illustrated, has angulated whorls unlike $P$. goweri and unlike Clark's (1932, p. 833, pl. 20, figs. 1-3) Fusinus cf. F. hannibali Clark and Arnold, which Kanno included as a synonym of his recently named Alaskan species. Clark's specimens, although poorly preserved, have a rounded whorl profile and a lower rib count (see illustrations in Addicott and others, 1971, figs. 2a, 2d-2f). Priscofusus goweri differs from $P$. stewarti in having axial ribs rather than nodes, or elongated nodes, on the shoulder of the body whorl. Moreover, the whorls are rounded rather than angulated in profile. The axial ribs on $P$. goweri are narrower and more numerous than on $P$. hannibali (Clark and Arnold, 1923, pl. 30, figs. 1, 2), an early Miocene species from the Sooke Formation of southwestern Vancouver Island, British Columbia. It seems most likely that Clark's (1932) poorly preserved specimens are conspecific with $P$. hannibali, as originally indicated.

\section{Priscofusus slipensis, n. sp. \\ Plate 2, figure 13}

A well-preserved, nearly complete specimen of Priscofusus from exposures near Slip Point is conspecific with Moore's (1963, p. 42, pl. 6, figs. 8, 11) Priscofusus n. sp.? This species is characterized by strongly angulated whorls. On the penultimate whorl, the axial ribs extend from suture to suture; at the medial angulation, they form a thin, spirally elongated node. On the lower two thirds of the penultimate whorl, fine secondary spiral cords alternate with the primary spiral cords. The body whorl has 12 vertically oriented axial ribs 
that are strongest in the central part of the whorl just below the angulation. These ribs quickly fade out above the angulation and do not reach the suture. Spiral sculpture on the slightly concave subsutural shoulder consists of finely beaded primary spiral cords that are separated by fine secondary threads of variable strength. The same pattern continues below the angulation with the infrequent addition of a tertiary spiral thread.

The holotype (SUPTC 154049) is from University of Washington locality 490 . It is $27 \mathrm{~mm}$ high and $16 \mathrm{~mm}$ wide.

The sculpture of Priscofusus slipensis is identical to that of the specimen from near Spencer Creek, Lincoln County, Oreg., described by Moore (1963, p. 42, pl. 6, fig. 11) as Priscofusus n. sp.? This species differs from the known species of Priscofusus from the eastern North Pacific margin in having vertically elongated nodes that extend across the penultimate whorl and across the medial third of the body whorl. Its occurrences here and in the Astoria Formation of Oregon define a late early Miocene to middle Miocene range. Priscofusus hannibali (Clark and Arnold, 1923, p. 158, pl. 30, figs. 1, 2) from the lower Miocene Sooke Formation of Vancouver Island is similar to $P$. slipensis but differs in having rounded axial ribs that extend from the suture to near the base of the body whorl.

Priscofusus cf. P. stewarti (Tegland, 1933) [pl. 2, fig. 15]. A small crushed specimen with angulated and strongly noded whorls resembles the early Miocene species $P$. stewarti from the upper Oligocene type Blakeley Formation near Seattle, Washington. The angulation on the body whorl is relatively close to the suture. The angulated and strongly noded whorls differentiate $P$. stewarti from $P$. goweri $\mathrm{n}$. sp. from the same locality. If correctly identified as $P$. stewarti, this occurrence constitutes a range extension from the upper Oligocene Echinophoria rex zone (Durham, 1944).

\section{VOLUTIDAE}

Musashia indurata (Conrad, 1849) [pl. 3, fig. 27]. An undoubted specimen of the coarsely ribbed volute, Musashia indurata, was collected from the basal part of the Clallam Formation near Pillar Point (loc. M4050). The axial ribs are well developed on the spire but weaker and irregularly spaced on the body whorl. About 18 axial ribs occur on the last half of the penultimate whorl and the first half of the body whorl. This rib count is the same as that on specimens of $M$. indurata from the Astoria Formation of Oregon (Moore, 1963 , p. 43-44, pl. 7, figs. 1-9, 11; pl. 8, figs. 1-5). Faint spiral sculpture is evident on the upper part of the body whorl of the Clallam specimen, and the ribs show the characteristic curvature just below the suture. Musashia corrugata (Clark, 1932, p. 831-832, pl. 21, figs. 4, 5, 11) from the Gulf of Alaska has fewer axial ribs than $M$. indurata, about 13-15 (Kanno, 1971, p. 125), and a much more slender shell. The Alaskan species is reported from the Oligocene and early Miocene (Kanno, 1971, p. 126); the earlier provincial occurrence of $M$. corrugata and its morphological similarities to $M$. indurata suggest that it could be the precursor of the early to middle Miocene species.

Musashia indurata had previously been recorded only from the provincial middle Miocene. The Clallam record constitutes a definite range extension from the middle Miocene into the provincial early Miocene. Musashia indurata was doubtfully reported from the lower Miocene of the southern San Joaquin basin on the basis of fragmental material (Addicott, 1970a, p. 105, pl. 13, fig. 8).

\section{CANCELLARIIDAE}

Cancellaria birchi Addicott (1970a) [pl. 2, figs. 36, 37]. A moderately high-spired cancellariid from the basal part of the Clallam is somewhat more spinose than specimens from the type locality in central California but is otherwise similar. This record of $C$. birchi constitutes a range extension; $C$. birchi was previously known only from the provincial middle Miocene of the southeastern San Joaquin basin, California.

Cancellaria cf. C. oregonensis Conrad (1865) [pl. 2, figs. 26-28]. Poorly preserved specimens from two localities resemble a slender, relatively high-spired form of C. oregonensis Conrad from the Astoria Formation of Oregon (Moore, 1963, pl. 9, fig. 19). The axial ribs on the Clallam specimens are variable and generally fewer in number than on the material from the Astoria Formation. As with other species of Cancellaria from the Clallam, decortication makes species identification difficult.

Cancellaria cf. C. siletzensis Hanna (1924) [pl. 2, fig. 29]. This doubtfully identified cancellariid is based on a poorly preserved, deformed specimen from near the base of the Clallam Formation. It has the fine spiral sculpture and broadly rounded axial ribs characteristic of $C$. siletzensis; heretofore, $C$. siletzensis has been reported from the Astoria Formation of Oregon (Moore, 1963, p. 44, pl. 9, figs. 2, 5). One of the Astoria localities, USGS locality 18901 , may be from the uppermost part of the Nye Mudstone according to recent geologic mapping (Snavely and others, 1976) and of provincial early Miocene age.

Cancellaria cf. C. simplex Anderson (1905) [pl. 2, figs. 30, 31]. Decorticated specimens from USGS locality M4049 near the base of the Clallam Formation 
have widely spaced, swollen axial ribs and a relatively large body whorl similar to the strongly sculptured form of C. simplex Anderson of Addicott (1970a, pl. 14, figs. 19, 20, 27), a Miocene species from central and southern California. These doubtfully identified specimens are much closer to $C$. simplex than they are to typical C. oregonensis from the Astoria Formation. If this doubtful occurrence could be validated by better material, it would constitute a range extension from the middle Miocene into the early Miocene.

Cancellaria wynoocheensis Weaver (1916b) [pl. 2, figs. $32,35,38$ ]. This is possibly the most distinctive cancellariid in assemblages from the Clallam Formation. It is characterized by fine spiral ribbing and numerous, closely spaced axial folds. There are considerably more axial folds on this species than on $C$. oregonensis with which it occurs in the Astoria Formation of Oregon and southwestern Washington. This record is a range extension from the provincial middle Miocene into the provincial early Miocene.

\section{TURRIDAE}

Xenuroturris antiselli (Anderson and Martin, 1914) [pl. 2, fig. 22, pl. 3, figs. 21, 23]. A poorly preserved, decorticated turrid from the Clallam has spiral ribbing identical to Moore's (1963, pl. 10, figs. 6, 12, 13, 15) "Thesbia" antiselli (Anderson and Martin) from the Astoria Formation of Oregon. Moore's species was subsequently included as a coarsely ribbed form of $X$. antiselli" (Anderson and Martin) by Addicott (1970a, p. 128). This form is characterized by five coarse, straplike spiral ribs on the body whorl. It has been doubtfully recorded from the lower Miocene Jewett Sand of the San Joaquin basin, California (Addicott, 1970a).

?Rectiplanes sp. [pl. 2, fig. 33]. The external mold of a small, high-spired turrid seems to represent Rectiplanes. The proportions and the smoothly rounded profile of the whorls are similar to late Tertiary and Quaternary specimens from the Pacific coast. The closest described species from the Miocene of Oregon or Washington is Spirotropis washingtonensis Etherington (1931, p. 113, pl. 14, figs. 8, 22, 34) from the Astoria Formation. This species differs from ?Rectiplanes sp. in having a prominent, and sometimes noded, angulation on the body whorl and on some of the whorls of the spire.

\section{Ophiodermella olympicensis, n. sp. \\ Plate 3, figures 18-20, 22}

A small turrid characterized by strongly developed spiral ribbing is described as Ophiodermella olympicensis $\mathrm{n}$. sp. This species has distinctive characteristics and can therefore be differentiated from known
Miocene turrids with little difficulty. It is known mostly from internal molds which provide an incomplete record of details of surface sculpture. The spire is sculptured by 4 spiral cords. Two primary spiral cords are flanked by a weaker spiral cord at the anterior suture and a fine spiral cord posteriorly. The rounded body whorl has eight spiral ribs that tend to be strongest on the medial part of the whorl. The uppermost spiral rib varies in strength and position with respect to the suture; sometimes it adjoins the suture but usually it is separate. This spiral rib and the next two spiral ribs may be separated from the lower five by a somewhat broader interspace (pl. 3, fig. 19). On many specimens, however, all the spiral ribs are of about equal length and may be equidistant from each other (pl. 3, fig. 18). The posterior notch is fairly deep and similar in configuration to species included in the genus by Powell (1966, p. 92).

The holotype (USNM 215992) is from USGS locality M4051. It is $16 \mathrm{~mm}$ high and $6.5 \mathrm{~mm}$ wide. Paratypes from this locality (USNM 215993, 215994, 215995) range from 11.5 to $17 \mathrm{~mm}$ in height.

This species is assigned to Ophiodermella because of the configuration of the posterior siphonal notch and because the general aspect of ribbing is similar to the Pliocene species $O$. graciosana (Arnold, 1907, p. 430431, pl. 54, fig. 18).

Ophiodermella olympicensis differs from $O$. workensis (Etherington, 1931, p. 111-112, pl. 14, figs. 12, 24, $26,28,30$ ) from the Astoria Formation of southwestern Washington in having a rounded, rather than flattened, whorl profile and in having bolder spiral ribbing. Xenuroturris antiselli (Anderson and Martin) resembles this species somewhat but it differs in having an angulate body whorl with a concave profile between the angle and the posterior suture.

Ophiodermella olympicensis is most likely to be confused with $O$. muirensis (Clark and Arnold, 1923, p. 157-158, pl. 30, figs. 4-6), an older early Miocene species from the Sooke Formation, Vancouver Island, British Columbia. The Sooke species differs from $O$. olympicensis in having more spiral ribs and in lacking the gap between the two prominent cords on the body whorl.

A similar and possibly related species identified as Ophiodermella n. sp. by Addicott (in Wolfe and McKee, 1972) occurs in the Astoria Formation of the Grays River quadrangle, southwestern Washington. This turrid has similar spiral sculpture (pl. 3, figs. 24, 25) but seems to differ in having a very wide interspace between the upper two or three spirals and the lower set of five. Because of these minor differences, it is doubtfully included with the Clallam species as Ophiodermella cf. O. olympicensis. This species also oc- 
curs in the nearby Raymond quadrangle (USGS loc. M2287) in southwestern Washington.

Megasurcula cf. M. wynoocheensis (Weaver, 1912) [pl. 3, figs. 16, 17]. A very well preserved Megasurcula from near Slip Point is similar to $M$. wynoocheensis (Weaver, 1912, p. 70-71, pl. 9, figs. 87-89), a middle Miocene species from the upper part of the Astoria Formation of southwestern Washington. It resembles a rather low-spired form of this species reillustrated by Weaver (1942, p. 527, pl. 98, fig. 8) but it differs in having a less concave subsutural slope. Another difference is in the much closer position of the nodes to the posterior edge of succeeding whorl. Megasurcula cf. $M$. wynoocheensis is differentiated from $M$. condonana (Anderson and Martin), a Miocene species from Oregon and California, on the basis of its much higher and less evenly conical spire.

\section{PELECYPODS}

\section{NUCULIDAE}

Acila conradi (Meek, 1864) [pl. 3, figs. 1-3]. This Acila is of fairly common occurrence in the Clallam Formation. It has not been found in the stratigraphically lowest collections from the Clallam near Pillar Point (USGS locs. M4050 and M5879). The lowest occurrence is in a float collection near Slip Point representing an interval from 40 to $110 \mathrm{~m}$ above the base of the formation (USGS loc. M4681). This species commonly has a secondary bifurcation of the radial rib pattern. Strong concentric ribbing is developed near the ventral margin on most of the larger specimens. This species has been recorded from many localities of Miocene age by Schenck (1936, p. 84) including one California early Miocene record from the Freeman Silt of Addicott (1970a), a unit that contains foraminiferal assemblages of early Saucesian age. A previous record from the Hoh Formation of Schenck (1936, p. 83-84) of the western Olympic Peninsula, Wash., represents a second early Miocene occurrence because it occurs there with the early Miocene index species Vertipecten fucanus (Dall). Although this species has long been thought to be restricted to rocks of provincial middle Miocene age, there are at least three early Miocene records, therefore the occurrence in the Clallam is not a range extension.

\section{NUCULANIDAE}

Nuculana calkinsi (Moore, 1963) [pl. 3, figs. 4, 6, 10, 12-14]. This species occurs in molluscan assemblages from the finer grained strata of the Clallam Formation. Specimens are characterized by centrally located beaks, strongly inflated valves, and equally spaced ribbing. Many of the specimens are deformed, especially those from localities M4049 and M5878. Some individuals are larger than Moore's (1963) material from the Nye Mudstone and the Astoria Formation of Oregon, and others tend to be somewhat more elongate.

Nuculana chehalisensis (Weaver, 1912) [pl. 3, fig. 11]. A small species previously reported from the middle Miocene of southwestern Washington, Oregon, and central California (Etherington, 1931, p. 66) occurs in an assemblage from what appears to be the highest part of the Clallam Formation (USGS loc. M4678). This nuculanid is relatively high in proportion to its length and has a strongly concave posterior dorsal slope. It has been compared with $N$. eparchis Moore (1963, p. 55), but it differs from that species by its less elongate valves and, also, by its coarser concentric sculpture.

Nuculana cf. N. elmana Etherington (1931) [pl. 3, figs. 8, 9]. Nuculanids from the lower $40 \mathrm{~m}$ of the Clallam Formation near Slip Point resemble the moderately elongate species $N$. elmana Etherington from the Astoria Formation of the Grays Harbor basin, southwestern Washington. The principal difference between them is the somewhat more pointed posterior of the specimens from the Clallam. This taxon differs from $N$. calkinsi (pl. 3, figs. 10, 12, 14) in having a long relatively straight posterior dorsal slope and in lacking the faint sinus in the anterior part of the valves.

Other nuculanids that are too poorly preserved for specific identification occur in the collections from localities M4050, M4414, M4681, and M4683.

Yoldia supramontereyensis Arnold (1908) [pl. 3, figs. $7,15]$. Specimens from a few localities in the Clallam represent the initial record of this species north of the type area in the San Francisco Bay region of central California. Material from locality M4680 indicates some variation in the concavity of the posterior dorsal slope. The beaks tend to be situated medially which permits this species to be differentiated from the Oligocene to middle Miocene species $Y$. tenuissima Clark (1918, p. 78-79, pl. 8, figs. 5, 9). This record constitutes a range extension into the provincial lower Miocene; the holotype is from the unnamed sandstone of Dibblee (1966) which overlies the Page Mill Basalt that has been dated as $14.4 \pm 2.4$ m.y. (Turner, 1970 , $p$. 106). Benthonic foraminifers from this sandstone are of provincial middle Miocene (Relizian or Luisian) age (Clark, 1968, p. 177). Until now all records of $Y$. supramontereyensis were from strata of provincial middle Miocene age (Loel and Corey, 1932).

Undetermined, poorly preserved specimens of Yoldia from localities M4681, M4683, and M4684 may represent $Y$. supramontereyensis. 


\section{SOLEMYIDAE}

Archarax dalli (Clark, 1925) [pl. 3, fig. 5]. Specimens of Solemya from the lowermost part of the Clallam Formation near Pillar Point (USGS loc. M4050) are identical to probable topotypes of $A$. dalli from the upper member of the Twin River Formation. The outline of the valves and the position of the beaks are the same. This species is difficult to distinguish from the middle Miocene species $A$. ventricosa (Conrad). Weaver (1942) and Tegland (1933) cite the more posterior location of the beaks on $A$. dalli as being the significant specific determinant. Tegland (1933, p. 103) separated $A$. ventricosa from $A$. dalli on the basis of two large quadrate specimens from the upper Eocene and lower Oligocene Keasey Formation that were later named $A$. willapaensis (Weaver, 1942, p. 21-22). According to Weaver (1942, p. 20), the length of the anterior segment of the dorsal margin averages 75 percent of the length of the shell on $A$. dalli, whereas on $A$. ventricosa it averages only 60 percent. This means of differentiation seems suspect because the position of the beaks on the lectotype of $A$. ventricosa is about 75 percent of the length of the dorsal margin (Moore, 1963, pl. 11, fig. 8). Although the two species are very similar, they do seem to differ in the outline of the valves. Specimens of $A$. ventricosa, including the paratype and the lectotype (Moore, 1963, pl. 11, figs. 8, 11), are much higher in proportion to their length than are specimens of $A$. dalli. A. dalli is known from the upper member of the Twin River Formation and the basal part of the Clallam. A. ventricosa is not known to occur in strata older than middle Miocene along the Pacific coast; a late Oligocene or early Miocene record attributed to Tegland (1933) by Moore (1963, p. 52) is in error.

\section{ARCIDAE}

Anadara aff. A. lakei (Wiedey, 1928) [pl. 5, figs. 8, 9]. Decorticated specimens of an Anadara from the lowest part of the Clallam Formation near Pillar Point (USGS locs. M4050 and M5879) are similar to A. lakei, a middle Miocene species from central California. Identification of these specimens is doubtful owing to their poor preservation. They have about 25 ribs that are grooved medially. This Anadara is similar to the late Oligocene to early Miocene species A. submontereyana (Clark, 1918 , p. 128-129, pl. 16, fig. 2) from California but has more radial ribs-25 rather than 22 to 24 . Anadara devincta (Conrad), the common Miocene species from the Astoria Formation of Oregon and southwestern Washington which occurs stratigraphically higher in the Clallam Formation, can be readily differentiated from this species by its much higher rib count-29-32 (Reinhart, 1943, p. 44).

Anadara devincta (Conrad, 1849) [pl. 5, fig. 10]. This
Anadara occurs in strata that appear to be near the top of the Clallam Formation near the center of the syncline between Pillar Point and Slip Point (Gower, 1960). This species is distinguished from $A$. aff. A. lakei (Wiedey), which occurs in the lower part of the Clallam Formation, by having a larger number of radial ribs about 29 rather than 25 . As shown by Reinhart (1943), the number of radial ribs is a critical specific character in this genus. The ribs are split by two grooves in the anterior part of the valve and by a single groove in the medial and posterior parts (pl. 5, fig. 10). The present specimens are identical to the split-ribbed form of $A$. devincta of Moore (1963, p. 59-61) which occurs in both the Nye Mudstone (USGS locs. 18830, 18831, 18941, and 19050) and the Astoria Formation in the Newport Embayment, Oreg.

\section{GLYCYMERIDIDAE}

Glycymeris sp. [pl. 5, fig. 3]. Specifically indeterminate internal molds of Glycymeris occur at two localities (M4414 and M4684) in the Clallam Formation. The genus has not previously been recorded from this formation nor has it been found in the upper member of the Twin River Formation.

\section{MYTILIDAE}

Modiolus n. sp.? aff. M. restorationensis Van Winkle (1918) [pl. 5, fig. 5]. A rather small Modiolus with weakly inflated valves occurs in the lowermost part of the Clallam Formation (locs. M4050 and NP161). It is similar to $M$. restorationensis Van Winkle, a late Oligocene species from western Washington, but differs in having a convex, rather than straight or concave, dorsal margin and a less broadly flattened extremity. These differences suggest that it is an undescribed species, but there are too few specimens to rule out the possibility that it might be a form of $M$. restorationensis.

Mytilus n. sp. aff. M. tichanovitchi Makiyama (1934) [pl. 5, figs. 1, 2, 16, 18]. An undescribed rugose mytilid from the Clallam Formation resembles Mytilus tichanovitchi Makiyama (1934, p. 134-135, pl. 5, figs. 11, 12) from the Miocene of Hokkaido, Japan (pl. 5, fig 14), and $M$. ochotensis (Slodkewtisch, 1938, p. 117, pl. 49 , fig. 4 , pl. 50, fig. 1), presumably a synonym of $M$. tichanovitchi from the Miocene of Kamchatka. The Clallam species has strongly inflated valves characterized by a broad umbonal angle, a flared dorsal margin, and a strong umbonal ridge together with a secondary ridge occupying the posterior part of the depression between the ridge and the dorsal wing (pl. 5, figs. 1, 2). The dorsal alation on specimens from the Clallam is of variable strength owing, in part, to deformation of 
most of the specimens. The secondary ridge distinguishes the Clallam species from $M$. tichanovitchi. As noted by Allison and Addicott (1976), this Mytilus n. sp. also occurs in strata of provincial early Miocene age in central California and in strata of early middle Miocene age (Gladenkov, 1974) in western Kamchatka. The California occurrence is based on specimens from the southern San Joaquin basin that have been confused with $M$. middendorffi Grewingk (Addicott, 1965). Although the two species resemble each other superficially, the margins of the valves of Mytilus n. sp. are straight whereas those of $M$. middendorffi fold sinuously. The Kamchatka record is based on specimens figured by Il'ina (1963, pl. 11, figs. 1, 6) from the Kuluven Suite, possibly erroneously, as $M$. ochotensis Slodkewtisch and on an additional specimen from the same unit figured by Allison and Addicott (1976, pl. 2, figs. 2, 5).

\section{Solamen snavelyi, n. sp.}

Plate 4, figures 6, 9

Previously undescribed elongate, strongly inflated specimens of Solamen similar to the Oligocene species $S$. porterensis (Weaver, 1912, pl. 14, fig. 116) are here named $S$. snavelyi. The elongate-ovate valves of this species are sculptured by 100 or more fine flat-topped ribs. In the medial part of the valve, these ribs are separated by very narrow interspaces. Near the anterior margin, the radial ribs are much finer and the interspaces are relatively wider. Irregularly spaced concentric growth lines, some of which are strongly constricted, occur at increasingly closely spaced intervals toward the ventral margin.

The holotype (USNM 216008) is from USGS locality M4051. It is $14 \mathrm{~mm}$ long and $21 \mathrm{~mm}$ high. A paratype (USNM 216007) from USGS locality M4050 is $14 \mathrm{~mm}$ long and $19 \mathrm{~mm}$ high.

Solamen porterensis, an Oligocene species from Washington, differs from $S$. snavelyi in having bifurcating radial ribs and more quadrate valves as indicated by a topotype (pl. 4, figs. 3,11) from Porter Bluffs, Wash. Crenella cf. C. porterensis Weaver (Moore, 1963, p. 63, pl. 15, fig. 6) from the Astoria Formation of Oregon seems to belong to $S$. porterensis in view of its similar shape and pattern of bifurcating ribs. If so, it represents a range extension from the Oligocene "Lincoln" Stage and the lower part of the Matlockian or "Blakeley" Stage (Durham, 1944) to the provincial middle Miocene.

Solamen snavelyi also occurs in the Astoria Formation of southwestern Washington (Addicott in Wolfe and McKee, 1972, table 13, as Crenella cf. C. porteren- sis Weaver). The provincial range of this species is from the early Miocene to the middle Miocene.

This species is named for Parke D. Snavely, Jr., in recognition of his contributions toward deciphering the geological history of western Oregon and Washington.

\section{PECTINIDAE}

Vertipecten fucanus (Dall, 1900) [pl. 4, figs. 1, 2, 5, 7, $10,12]$. This pectinid is the most characteristic mollusk in assemblages from the Clallam Formation. It is usually represented by disassociated valves, complicating, somewhat, differentiation from fragmental specimens of the somewhat similar giant pectinid, Patinopecten propatulus (Conrad), a middle Miocene species from the Pacific Coast. The left valves of these species are distinct but the ribbing of the right valves, as noted by Moore (1963, p. 65), is similar. There are, however, important morphological differences between the right valves of these two giant pectinids that have not been previously considered. The ears of $V$. fucanus, for example, are relatively much larger than those of $P$. propatulus. Specifically, the length of the ears on specimens of $V$. fucanus is considerably more than half the width of the valves whereas on $P$. propatulus the ears are less than half the width of the valves. A second difference is the initially flat or slightly concave profile of right valves of $V$. fucanus during early, growth stages. This profile contrasts with the regularly convex profile of $P$. propatulus. In adult specimens of $V$. fucanus, the initially flat profile of $V$. fucanus usually develops into a gently convex profile similar to that of $P$. propatulus. Finally, the ribbing on right valves of $V$. fucanus is much more irregular than on $P$. propatulus, especially in the lateral areas. Many specimens of $V$. fucanus have one or more irregular ribs in the medial part of the disk and most specimens have a widening and deepening of the medial interrib corresponding to the strongly raised opposing rib of the left valve.

Some earlier workers (Arnold and Hannibal, 1913; Arnold, 1906; and Weaver, 1916a) identified both of these large pectinids in assemblages from the Clallam. Study of available collections reinforces the apparent conclusion of later investigators (Etherington, 1931; Durham, 1944) that there is only one large pectinid, $V$. fucanus, in the Clallam. All the left valves examined are referable to $V$. fucanus because of the characteristic pattern of a strongly raised medial rib and somewhat less accentuated flanking ribs that divide the disk into quadrants. These valves also differ from those of $P$. propatulus in being much more convex.

Specimens in the collections average about 80-90 $\mathrm{mm}$ in greatest diameter. These averages are misleading because the relatively small specimens are easiest to collect. In the field, most specimens exceed $100 \mathrm{~mm}$ 
in maximum diameter, and there are several specimens in the stratigraphic collections that are as large as $110-120 \mathrm{~mm}$. The right valves have 17 or 18 somewhat irregular flat-topped ribs. This valve also has a reticulate, or honeycombed, microsculpture that covers both the ribs and the interspaces. There are usually 15 or 16 crested ribs on the left valves; the medial rib is much stronger than any of the others and most are scaly or imbricated. Both valves have fine, irregular lateral ribs.

As indicated elsewhere in the text, Vertipecten fucanus seems to be a very useful species in biostratigraphic correlation of Miocene formations in the Pacific Northwest States. Its restricted stratigraphic occurrence in the Nye Mudstone of western Oregon and the Jewett Sand of central California is indicative of provincial early Miocene age. It also occurs in the Hoh rock assemblage of Rau (1973) along the western side of the Olympic Peninsula, Wash. (loc. M4146) with shallow-water mollusks that also occur in the Clallam and are presumably coeval.

\section{LUCINIDAE}

Lucinoma acutilineata (Conrad, 1849) [pl. 5, figs. 4, 7, 15]. Scattered and usually poorly preserved specimens of this lucinid occur in some parts of the Clallam Formation. As is characteristic of this species, the density of concentric lamellae is variable, but the spacing is equidistant over the greater part, if not all, of the valves (Moore, 1963, p. 70). This species is almost always preserved with articulated valves. It ranges from the middle part of the provincial Oligocene (Hickman, 1969) to the middle Miocene (Addicott, 1973). It is difficult to distinguish this species from some of the late Oligocene specimens from the Blakeley Formation of Washington figured as L. hannibali (Clark) by Tegland (1933, pl. 8, figs. 10, 12). The holotype of L. hannibali (Clark, 1925, pl. 22, figs. 2, 4) differs from $L$. acutilineata in having less regularly rounded valves and much more anteriorly situated beaks. The early Miocene species L. columbiana (Clark and Arnold, 1923, p. 144-145, pl. 25, fig. 2) that is from the Sooke Formation of Vancouver Island may be a synonym of $L$. acutilineata.

\section{THY ASIRIDAE}

Conchocele disjuncta Gabb (1869) [pl. 6, fig. 7]. The essentially straight anterior margin of this species permits differentiation from the similar Tertiary species $C$. bisecta (Conrad) which has a concave anterior margin and more prominent umbones (Bernard, 1972). Many Cenozoic molluscan specialists have considered $C$. disjuncta to be a junior synonym of $C$. bisecta (see, for example, discussions in Moore, 1963, and Bernard, 1972). Although C. disjuncta is sometimes treated as a deep-water taxon, a modern northeastern Pacific occurrence from only $10 \mathrm{~m}$ was described by Kanno (1971). Conchocele disjuncta occurs in collections from the lowest part of the Clallam Formation.

\section{UNGULINIDAE}

Felaniella sp. [pl. 5, fig. 17]. The outline of a small bivalve from locality M4413 is suggestive of Felaniella, a fairly common genus in Oligocene and Miocene faunas from the Pacific Coast States. Felaniella parilis (Conrad) was reported from Slip Point, about a mile west of locality M4413, by Etherington (1931, checklist facing p. 31).

\section{CARDITIDAE}

Cyclocardia subtenta (Conrad, 1849) [pl. 5, fig. 12; pl. 6 , figs. 9, 10]. Specimens from the Clallam have about 22 radial ribs that become narrower toward the posterior part of the valve. The outline of the valves is variable and the beaks usually are prominent. Cyclocardia castor (Dall, 1909, p. 116, pl. 11, figs. 1, 3) from the upper member of the Twin River Formation, on the east side of the mouth of East Twin River, has a similar rib count and valve outline. It may well be a synonym of C. subtenta, but according to Weaver $(1942$, p. 139 140 ) it differs in having a more deeply impressed lunule and weaker but broader radial ribs. Cyclocardia yakatagensis (Clark) from the upper part of the Poul Creek Formation, Gulf of Alaska, may also be a synonym of this species. It has a similar rib count, 23-25 radial ribs. The form named by Dall (1909, p. 115) as "Venericardia subtenta var. quadrata" from specimens collected near Slip Point in the vicinity of USGS locality M4413 ("one mile east of Clallam Bay") was differentiated from C. subtenta on the basis of its larger, more quadrate valves. Dall's taxon, however, falls within the range of variation of $C$. subtenta (Moore, 1963, p. 70).

\section{CARDIIDAE}

Clinocardium n. sp. aff. C. nuttalli (Conrad, 1837) [pl. 5, fig. 13 ; pl. 6 , fig. 8]. A few poorly preserved cardiids from the Clallam Formation may represent an undescribed species. Although decorticated, specimens of Clinocardium n. sp. appear to have had at least 18 coarse ribs anterior of the posterior inflection. The ribs on one specimen (pl. 5, fig. 13) are broad and rather flat topped. The other specimens are decorticated to such an extent that the original rib configuration cannot be determined. The beaks are inclined as in other species of Clinocardium. In all probability, this is the same 
species as Moore's (1963, p. 73, pl. 30, figs. 1, 2) Clinocardium aff. C. nuttalli (Conrad) from Coos Bay, Oreg. Clinocardium yakatagense (Clark, 1932, p. 813, pl. 18, fig. 8), a somewhat similar species from the middle Miocene part of the Yakataga Formation, Gulf of Alaska, has a similar rib count but differs at least from the best preserved specimen of Clinocardium n. sp. from the Clallam (pl. 5, fig. 13) in having crested rather than broadly rounded, or flat-topped, ribs. The other specimens from the Clallam are too poorly preserved to permit confident distinction from other middle Tertiary species. An early Miocene cardiid from the Sooke Formation of Vancouver Island, British Columbia, C. sookensis (Clark and Arnold, 1923, p. 145, pl. 22, figs. 1 and 2), differs from Clinocardium n. sp. in having almost twice as many radial ribs.

\section{MACTRIDAE}

Spisula albaria (Conrad, 1848) [pl. 6, fig. 3; pl. 7, figs. $2,3,11]$. This moderately large mactrid is characterized by a concave anterior dorsal slope, a convex posterior dorsal slope, and prominent beaks that tend to be situated posterior to the midline of the valves. The anterior extremity is pointed; the posterior extremity is much broader. Moore (1963, p. 82-83, pl. 28, figs. $1-3,5$; pl. 31 , figs. 9, 11) assigned all mactrids from the Astoria Formation of Oregon to this species, recognizing a broad range of variation in the outline of the valves. Reagan's (1909, p. 187, pl. 2, fig. 19) Mactra gibbsana Meek (pl. 7, figs. 2,3) is a synonym of this species as originally noted by Dall (1922). The anterior part of the specimen is deformed. This species is one of the most commonly occurring and abundant bivalves in the Clallam Formation. It is easily differentiated from other Spisula from the Clallam by its characteristic elongate-trigonal valves.

Spisula albaria goodspeedi Etherington (1931) [pl. 6, fig. 14; pl. 7, fig. 1]. This nearly equilateral trigonal mactrid was described from the upper Miocene Montesano Formation of Weaver (1912) of southwestern Washington. The unique outline of the valves permit differentiation from S. albaria, but in the context of the broad range of variation recognized by Moore (1963, p. 82-83), it would very likely be treated as only a form of the latter species. This species also occurs in the middle Miocene part of the Astoria Formation of southwestern Washington (Etherington, 1931).

Spisula cf. S. hannibali Clark and Arnold (1923) [pl. 6 , fig. 11]. This mactrid has an unusually broad apical angle and long, more or less straight, dorsal slopes. It is represented by poorly preserved material, consequently the identification is doubtful. Spisula hannibali has been reported from strata of provincial early Miocene age near Seattle that are correlated with the upper part of the "Blakeley" Stage (Durham, 1944). The principal difference between $S$. hannibali and both $S$. albaria and $S$. albaria goodspeedi is the unusually broad apical angle. As in the case of $S$. albaria goodspeedi, it seems possible that this taxon could fall within the broad range of variation of S. albaria recognized by Moore (1963, p. 82-83) although it was not included as a synonym of that species. Spisula equilateralis (Clark, 1932, p. 819-820, pl. 11, fig. 8), an early Miocene species from the upper part of the Poul Creek Formation, Gulf of Alaska (Kanno, 1971, p. 72), may be a synonym of $S$. hannibali but appears to differ in having relatively longer valves.

Spisula sookensis Clark and Arnold (1923) [pl. 6, figs. 1, 16]. Another Spisula originally described from the lower Miocene Sooke Formation of nearby Vancouver Island, Canada, occurs at a few localities in the Clallam. It is a large, thin-shelled mactrid similar in outline to the Miocene-to-Holocene species $S$. catilliformis (Conrad) (Packard, 1916, pl. 18, figs. 1, 2; Fitch, 1953, fig. 53). Both Spisula sookensis and $S$. catilliformis have a rib just below the posterior dorsal margin, but $S$. sookensis differs from $S$. catilliformis in having more quadrate valves with the beaks situated closer to the anterior extremity. It seems possible that some Miocene records of $S$. catilliformis from California (Loel and Corey, 1932, p. 170, 232, pl. 44, fig. 8; Packard, 1916, p. 286, pl. 9, figs. 1, 2) could be of this species. If so, a provincial early Miocene (Vaqueros Formation of Loel and Corey, 1932) to late Miocene (San Pablo Group of Clark, 1915) age would be indicated.

Spisula sp. [pl. 6, fig. 6]. A specimen from locality M4049 is so different from the other species in the Clallam that it is treated, tentatively, as a separate taxon. It is most similar to $S$. albaria, but the outline of the valves differs from this commonly occurring species in the anterior location of the beaks.

\section{SOLENIDAF}

Solen conradi Dall (1900) [pl. 6, fig. 12]. A small Solen with a slightly convex ventral margin and a straight or slightly concave dorsal margin is conspecific with $S$. conradi Dall (1900, p. 953), a species originally described from the Astoria Formation of Oregon. The few specimens from the Clallam are from the lowest $240 \mathrm{~m}$ of the formation. Solen conradi ranges from the early Miocene to the middle Miocene (Moore, 1963).

\section{TELLINIDAE}

Tellina emacerata Conrad (1849) [pl. 7, figs. 5, 7, 10]. This is the most commonly occurring tellinid in the Clallam Formation. It can be readily differentiated 
from the other Clallam tellinids by the prominent, inclined internal rib in the anterior half of the valve (pl. 7 , figs. 5,10 ). This feature is apparent on most of the Clallam specimens because practically all lack shell material. The plane of commissure is flexed posteriorly resulting in a slight bending of the valves. The surface is sculptured by very fine, evenly spaced concentric grooves. Reagan's (1909, p. 186-187, pl. 2, fig. 18) $T$. clallamensis is a synonym of this species; it is refigured on plate 7, figure 10. Tellina emacerata ranges from the early Miocene to the middle Miocene in Oregon and Washington. It may be represented by Tellina (Oudardia) sp. Kanno (1971, p. 75-76, pl. 10, figs. 4, 5) from the upper part of the Poul Creek Formation in the Gulf of Alaska region. In California, this species ranges from the late Oligocene to the late Miocene (Addicott, 1973, p. 32).

Macoma albaria Conrad (1849) [pl. 7, figs. 13-15, 17, 20]. This small tellinid, characterized by posteriorly located beaks and valves that are weakly flexed posteriorly, occurs at a few localities in the Clallam Formation. Almost all the right valves of this species have been bored by gastropods. The right valve is the more strongly flexed of the two valves. The flexing and the position of the borings near the middle of the right valve suggest that this species lived very close to the surface and that the plane of commissure was oriented parallel to the sediment-water interface with the right valve above the left one. This species and two other small Macomas from Oligocene and Miocene formations in Oregon and Washington, $M$. twinensis Clark and $M$. arnoldi Tegland, are very similar. Both $M$. albaria and $M$. twinensis Clark (1925, p. 96, pl. 12, fig. 7) have posteriorly located beaks and are much less strongly flexed posteriorly. As an alternative to discrimination as separate species, it seems possible that the two taxa could be treated as forms of a variable species. Macoma arnoldi Tegland (1933, p. 119-120, pl. 9, figs. 2-8), a small species of late Oligocene age, differs from these two in having higher, more trigonal shaped valves and more centrally located beaks (pl. 7, figs. 16, 19). Reagan's (1909, pl. 2, fig. 15) M. albaria could be $M$. arnoldi; as noted by Moore (1963, p. 50) it is not $M$. albaria.

Macoma arctata (Conrad, 1849) [pl. 7, figs. 4, 6, 8, 14, $18,22]$. The elongate valves of this large species are bent or flexed posteriorly as in the late Cenozoic species $M$. nasuta (Conrad); the. left valve is more strongly flexed than the right one. The beaks are located in the posterior part of the valve. Some specimens (pl. 7, figs. 8, 14), preserved with shell material or as internal molds, have faint radial ribbing in the anterior ventral part. Some of the best specimens are from locality M4051; the shell material has been leached but the exterior sculpture has been transferred to the internal molds and is fairly well preserved. This probably is the type locality for Reagan's $(1909$, p. 186 , pl. 1, fig. 17) Tellina arctata var. juana. The holotype of this taxon is refigured on plate 7 , figure 14 . Specimens from near the base of the Clallam (loc. M4049) may represent the earliest occurrence of large species of Macoma in Oregon and Washington. Material identified as M. arctata from the uppermost part of the Lincoln Creek Formation (Armentrout, 1975) could be coeval; the associated assemblage contains only a few species, none of which are diagnostic of provincial age. This species appears in the provincial late Oligocene in California (Addicott, 1973, p. 33). Its highest stratigraphic occurrence in California, Oregon, Washington, and Alaska (Moore, 1963; Kanno, 1971; Addicott, 1973 ) is in strata of middle Miocene age. This species also occurs in the western North Pacific where it has the same geological range. The oldest record is from the late Oligocene of Honshu Island, Japan (Kanno, 1960); the youngest (Il'ina, 1963, p. 81) from middle Miocene (Gladenkov, 1972, p. 169) strata of Kamchatka, Russia.

Macoma cf. M. twinensis Clark (1925) [pl. 6, fig. 5]. A few, small articulated tellinids from the Clallam Formation are doubtfully identified as Macoma twinensis. They are more elongate and have more centrally located beaks than the more commonly occurring specimens of Macoma albaria Conrad. Macoma twinensis was described from exposures of the upper member of the Twin River Formation about 2 miles west of Twin River (Weaver, 1942, p. 210). This species also differs from $M$. albaria in having more strongly flexed valves. Specimens of $M$. twinensis from near the base of the type section of Durham's (1944) Echinophoria apta zone (loc. M4032) are illustrated on plate 6 (figs. 2, 4, $13,15)$ and plate 7 (fig. 12). Identification of this species in the Clallam is doubtful because of the similarity to $M$. albaria and because the valves are not so strongly flexed as on undoubted specimens of $M$. twinensis. The latter condition could be due to deformation of the valves. Macoma twinensis ranges from the provincial late Oligocene to the early Miocene. The doubtful record of this species in the Clallam is the youngest in the Pacific Coast Tertiary.

Macoma astori Dall (1909) [pl. 7, fig. 21]. Significant morphologic features of this taxon are its pointed and relatively strongly flexed posterior extremity, its long and nearly straight posterior dorsal margin, and its almost medially located beaks. One moderately large specimen from the Clallam (pl. 7, fig. 21) is almost identical to Dall's type specimen (see Moore, 1963, p. 81, pl. 29, fig. 12). Macoma astori seems to be more similar to the late Tertiary and Quaternary species $M$. 
nasuta (Conrad) than to any of the other bent-nosed Oligocene and Miocene species from Oregon and Washington. Some paleontologists (Grant and Gale, 1931, p. 369; Faustman, 1964, p. 22; Talmadge, 1972, p. 413) consider $M$. lipara Dall (1916), a Pliocene to Holocene species, to be indistinguishable from $M$. astori and, by inference, a synonym of this species. This treatment seems inadvisable in view of longer, and straight rather than convex, posterior dorsal margin of $M$. astori. Moreover, the right valve of $M$. astori is much more strongly flexed than that of $M$. lipara.

Macoma sookensis Clark and Arnold (1923) [pl. 7, fig. 23 ; pl. 8, figs. $1,2,5$ ]. Left valves of a large, fairly thick shelled Macoma from the lowest $40-110 \mathrm{~m}$ of the Clallam Formation (USGS locs. M4681 and NP161) are identical to Clark and Arnold's (1923) species from nearby Vancouver Island, British Columbia. This species is similar to M. nasuta (Conrad), a commonly occurring modern taxon that ranges back into the Miocene. Like $M$. nasuta it has anteriorly located beaks and a ligamental nymph indicative of an elongate ligament. The overall shape of the valves is similar, but the valves of these specimens of $M$. sookensis are less strongly flexed and are broadly rounded, rather than pointed, posteriorly. This rounding plus the less strongly sloping posterior dorsal margin give the valves of this species a more quadrate outline than $M$. nasuta. Macoma sookensis seems to be restricted to strata of provincial early Miocene age.

Macoma n. sp. aff. M. secta (Conrad, 1837) [pl. 8, fig. 6]. A single specimen of an incomplete internal mold of a right valve, somewhat similar to Macoma secta, may represent an undescribed species. It is referred to the subgenus Rexithaerus because of the flange developed along the posterior dorsal margin. It differs from $M$. secta in being more elongate and in having a broadly truncate posterior margin. This taxon also differs from M. flagleri Etherington (1931, p. 85, pl. 10, figs. 3, 4) in having anteriorly, rather than centrally, located beaks. A specimen of M. flagleri is illustrated (pl. 8, fig. 3 ) for comparison. A widening of the dorsal margin just posterior to the beaks indicates that this bivalve had an external ligament.

Macoma n. sp. Moore (1963) [pl. 8, fig. 4]. An orbicular specimen that is almost as high as it is long appears to be the same as Moore's (1963, p. 81, pl. 29, figs. 10, 11) Macoma n. sp. from near Newport, Oreg. This species was described as "thin shelled, high in proportion to length, and perhaps almost circular in outline" (Moore, 1963, p. 81). Although recorded from the Astoria Formation (Moore, 1963), later mapping has shown that the seacliff localities 2-3 miles south of Newport are in the upper part of the Nye Mudstone (Snavely and others, 1969b, 1976). Data considered elsewhere in this report indicate a provincial early Miocene age for the Nye Mudstone.

\section{VENERIDAE}

Dosinia whitneyi (Gabb, 1866 [pl. 8, figs. 9, 10]. Small, orbicular specimens of Dosinia from localities M4414, M4683, M4684, NP160, and NP161 are identical with material from the Astoria Formation of Oregon identified as D. whitneyi (Gabb) by Moore (1963, p. 73, pl. 24, figs. 1-10). These specimens are sculptured by fine concentric ribs and are of variable outline owing to deformation. The genus is of very rare occurrence in the Miocene of Oregon where it is known definitely only from dredgings of middle Miocene age at Coos Bay (Moore, 1963, p. 73). It also occurs in middle Miocene strata in southwestern Washington (Etherington, 1931; Addicott in Wolfe and McKee, 1972, table 13) where it is also rare. The extremely small size of these specimens suggests that they may represent the northernmost limits of distribution of this warm-water genus during the early Miocene. Middle Miocene specimens from southwestern Washington (Etherington, 1931) and western Oregon (Moore, 1963) are of much smaller size than those from Oregon. The genus has been recorded from middle Miocene strata as far north as Kodiak Island, Alaska (lat $58^{\circ}$ N.), but that occurrence may have been related to a western North Pacific lineage (Addicott, 1969).

Katherinella angustifrons (Conrad, 1849) [pl. 8, figs. 7, $8,11-18]$. Specimens from the Clallam are extremely variable in outline and in thickness. Nevertheless they can be separated into two forms. One has inflated valves that tend to be of quadrate shape; the other is only weakly inflated, tends to attain a larger adult size, is relatively thin shelled, and is usually, but not always, more orbicular in outline. Some of the thin orbicular forms attain a relatively large size (pl. 8, fig. 18). The inflated form (pl. 8, figs. 15, 17) occurs in collections from locs. M4051, M4413, M4677, M4683, and NP163; the thin form (pl. 8, figs. 8, 12, 14, 16, 18) in M4049, M4050, M4414, M4684, and M5878. The inflated form is similar to the type and to specimens from the Nye Mudstone and the Astoria Formation of the northwest Oregon coast (Moore, 1963, pl. 24, figs. 11-14, pl. 25, figs. 1-3, 5-15, pl. 26, figs. 4-6, 8). Specimens from localities NP89, NP161, and NP163 are not differentiated. Katherinella arnoldi ethringtoni (Tegland, 1929, p. 283, pl. 23, figs. 12-14), described from the Clallam Formation and also recorded from the upper member of the Twin River Formation (Durham, 1944 , p. 149), is a synonym of this species.

Securella ensifera (Dall, 1909) [pl. 9, figs. 1-3, 5, 6, 9, $10,13]$. This species is one of the most abundant bivalves in the Clallam, however, most of the speci- 
mens are devoid of shell material thereby making specific identification difficult. The external concentric sculpture has, nevertheless, been partially preserved on many of the internal molds. On a few specimens the sculpture is so well preserved that the fine radial sculpture underlying the concentric ribbing is exposed. The original surface sculpture of $S$. ensifera consisted of bladelike concentric ridges gently inclined toward the beaks. Almost all the species, however, have undergone abrasion or decortication that has exposed a layer characterized by fine radial ribbing. This species has been treated systematically by Moore (1963, p. 75-76). Specimens described as Venus clallamensis and $V$. olympidea by Reagan (1909, p. 182-183, pl. 1, figs. 12 and 13) are synonyms of this species. These are refigured in this report (pl. 9, figs. 3, 13). Securella, a genus that became extinct during the provincial Pliocene, is differentiated from the similar warmwater genus Chione by its deeply sunken ligament and V-shaped pallial sinus (Parker, 1949). A specimen from the basal part of the Clallam identified as S. alaskensis (Clark, 1932, p. 815, pl. 18, figs. 2, 3) by Parker (1949, p. 588) and Chione sp. (Durham, 1944, p. 146) presumably belongs to this species. Clark's (1932) species from the middle Miocene part of the Yakataga Formation, Alaska [not Poul Creek Formation as stated by Parker (1949)—see Kanno (1971, p. 87)], may be a synonym of this species.

\section{HIATELLIDAE}

Panopea ramonensis (Clark, 1925) [pl. 9, fig. 15]. This species has consistently longer valves in proportion to the height than does $P$. abrupta, which also occurs in the Clallam Formation. The beaks on this species vary from medial to a position anterior to the midline of the valves (Addicott, 1973, p. 37-38). The elongate form of Panopea ramonensis was previously recorded and figured from the Clallam by Weaver (1942, p. 264, pl. 59, fig. 11). That record was used by Hickman (1969, p. 60) and Addicott (1973) in defining a middle Oligocene to middle Miocene range for this species. This range must be revised to middle Oligocene to early Miocene in keeping with the revised provincial age of the Clallam (Addicott, 1975).

Panopea abrupta (Conrad, 1849) [pl. 9, figs. 7, 8, 16]. This Panopea has more quadrate valves and occurs more commonly in the Clallam Formation than $P$. ramonensis. Panopea abrupta occurs in Miocene to Holocene formations along the Pacific coast and was recently recorded from the middle Oligocene of Oregon (Hickman, 1969, p. 65). Kanno's (1971, p. 93-94, pl. 11, fig. 3) Panopea n. sp.? from a locality in the upper part of the Poul Creek Formation, Gulf of Alaska, is very similar to $P$. abrupta, differing principally in having a strongly sloping anterior dorsal margin.

\section{THRACIIDAE}

Thracia trapezoides Conrad (1849) [pl. 9, figs. 4, 12]. This late Oligocene to Holocene species, originally described from the middle Miocene part of the Astoria Formation of Oregon, is fairly abundant in the Clallam Formation. It differs from the late Oligocene to early Miocene species T. schencki Tegland (1933, p. 112-113, pl. 6, figs. 6-11) and the Oligocene species $T$. condoni Dall (1909, p. 135-136, pl. 19, fig. 5) in having straight or slightly concave anterior and posterior segments along the ventral margin creating a lobate ventral margin. The ventral margin tends, therefore, to be more convex than in the-other species. A further difference is the generally larger size of the Oligocene species (Moore, 1963; Hickman, 1969). On most species of $T$. trapezoides, the umbonal ridge setting off the near-vertical posterior segment of the valve is much sharper than on older species. The valves of both $T$. schencki and $T$. condoni also tend to be longer in proportion to their height than those of $T$. trapezoides. The lowest stratigraphic occurrence of this species is in the Echinophoria rex zone of northwestern Washington (Durham, 1944).

Thracia cf. T. schencki Tegland (1933) [pl. 9, figs. 11, 14]. Small elongate specimens from locality M4051 near Slip Point seem to represent this species. Identification is doubtful because of limited material and poor preservation of the specimens. Thracia schencki Tegland has a much less convex dorsal margin and has more elongate valves than $T$. trapezoides. It also lacks the broad sinus between the posterior umbonal ridge and the midline of the valves that is characteristic of $T$. trapezoides.

\section{CEPHALOPODS}

\section{HERCOGLOSSIDAE}

Aturia angustata (Conrad, 1849). This species is doubtfully identified from a locality about $65 \mathrm{~m}$ above the base of the Clallam Formation (USGS loc. M5878). There is an undoubted record from the basal part of the Clallam Formation on the east flank of the anticline near Slip Point (Arnold and Hannibal, 1913, p. 588; Miller, 1947, p. 87). Aturia angustata is definitely identified from near the top of the underlying upper member of the Twin River Formation close to the mouth of Pysht River (Schenck, 1931) and is of more common occurrence in collections from the type section of the lower Miocene Echinophoria apta zone near the mouths of the Twin Rivers several kilometres farther east (Arnold and Hannibal, 1913; Durham, 1944). 
Occurrences of Aturia angustata in the California Miocene are very rare. The two records listed by Schenck (1931) are from strata northeast of Bakersfield, Calif., that are referable to the upper part of the "Vaqueros" Stage of Addicott (1972). The lowest of these records is from near the base of the Temblor Formation according to Schenck (1931). Records from Oregon (Moore, 1963) seem to be from the lower Miocene Nye Mudstone of the Newport Embayment or from the lower Miocene part of the Astoria Formation in more northern Miocene embayments. This taxon has not been recorded from the Astoria Formation in southwestern Washington. The fragmentary stratigraphic evidence points toward a pre-middle Miocene range for this species. Tentatively, it is considered to have become extinct during the later part of the provincial early Miocene.

\section{SCAPHOPODS}

\section{DENTALIIDAE}

Dentalium pseudonyma Pilsbry and Sharp (1898) [pl. 4 , figs. 4, 8]. This radially ribbed species is of less common occurrence in the Clallam than the larger smooth-shelled $D$. schencki Moore. Further differences from $D$. schencki are the relatively thinner shell and straighter, less tapered form.

Dentalium schencki Moore (1963) [pl. 5, fig. 11]. This relatively large smooth-shelled species, strongly tapered, is fairly abundant in the Clallam Formation. Both Dentalium schencki Moore and D. pseudonyma also occur in the middle Miocene part of the Astoria Formation of the Newport Embayment, Oreg. (Moore, 1963).

\section{FOSSIL LOCALITIES IN THE CLALLAM FORMATION, CLALLAM COUNTY, NORTHWESTERN WASHINGTON}

\author{
U.S. Geological Survey localities, Menlo Park register
}

M4049. Sea cliff and intertidal zone exposures near center of $\mathrm{E}^{1 / 2}$ of sec. 32 , T. 32 N., R. 11 W., 2,300 ft north, $1,300 \mathrm{ft}$ west of SE cor. sec. 32, T. 32 N., R. 11 W., Pysht 15-minute quadrangle. From three 1-m-thick beds in an interval between 191 and $207 \mathrm{~m}$ above the base of the formation. Collected by W. O. Addicott, 1968, and Addicott and J. W. Miller, 1974. Same as UCMP A3962.

M4050. Sea cliff and intertidal zone exposures $1,800 \mathrm{ft}$ north, $700 \mathrm{ft}$ west of SE cor. sec. 32, T. 32 N., R. 11 W., Pysht 15minute quadrangle. From interval $52-59 \mathrm{~m}$ above the base of the formation. Collected by W. O. Addicott, 1968 . Same as UCMP A3693.

M4051. Macoma arctata beds about $10 \mathrm{~m}$ thick exposed in sea cliff almost $1 \mathrm{~km}$ east of Slip Point, 4,550 ft north, $700 \mathrm{ft}$ west of SE cor. sec. 21, T. 32 N., R. 12 W., Pysht 71/2-minute quadrangle. Collected by W. O. Addicott, 1968.
M4413. Intertidal exposure of sandstone with scattered Vertipecten

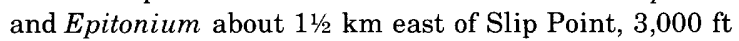
north, 2,400 ft east of SW cor. sec. 22, T. 32 N., R. 12 W., Pysht 15-minute quadrangle. Collected by W. O. Addicott, 1970, and Addicott and J. W. Miller, 1974.

M4414. Talus from seacliff exposure nearly $3 \mathrm{~km}$ east of Slip Point, $600 \mathrm{ft}$ north, $2,100 \mathrm{ft}$ east of SW cor. sec. 23, T. $32 \mathrm{~N}$., R. $12 \mathrm{~W}$., Pysht 15-minute quadrangle. From an interval approximately $40-110 \mathrm{~m}$ above the base of the formation. Collected by W. O. Addicott, 1970.

M4675. Seacliff and intertidal zone exposures about two-thirds of a kilometre west of Pillar Point, $100 \mathrm{ft}$ north, $500 \mathrm{ft}$ east of NW cor. sec. 3 , T. 31 N., R. 11 W., Pysht 15-minute quadrangle. Collected by W. O. Addicott and J. E. Pearl, 1971.

M4677. Intertidal zone exposures at north end of gravel beach at Slip Point, 4,900 ft north, $200 \mathrm{ft}$ west of SE cor. Clallam Bay 15-minute quadrangle. Approximately $180 \mathrm{~m}$ above the base of the formation. Collected by W. O. Addicott, 1971.

M4678. Natural exposure on south side of logging road at top of steep sea cliff, $600 \mathrm{ft}$ north, $800 \mathrm{ft}$ west of SE cor. sec. 25, T. 32 N., R. 12 W., Pysht 15-minute quadrangle. Elevation $880 \mathrm{ft}$. Near the top of the formation. Collected by W. O. Addicott, 1971, and Addicott and J. W. Miller, 1974.

M4679. Intertidal zone exposure about $4 \mathrm{~km}$ west of Pillar Point, 4,400 ft north, $300 \mathrm{ft}$ east of SW cor. sec. 32 , T. 32 N., R. $11 \mathrm{~W}$., Pysht 15-minute quadrangle. Collected by W. O. Addicott, 1971.

M4680. Intertidal zone exposure about $150 \mathrm{~m}$ southeast of M4679, 4,100 ft north, $400 \mathrm{ft}$ east of SW cor. sec. 32 , T. 32 N., R. 11 W., Pysht 15-minute quadrangle. Collected by W. O. Addicott, 1971.

M4681. Same as M4414. Collected by W. O. Addicott, 1971.

M4683. Intertidal zone exposure about $1 \frac{1}{1} 2 \mathrm{k}$ west of Pillar Point, $500 \mathrm{ft}$ north, $3,700 \mathrm{ft}$ east of SW cor. sec. 33, T. 32 N., R. 11 W., Pysht 15-minute quadrangle. Collected by W. O. Addicott and J. E. Pearl, 1971.

M4684. Intertidal zone exposure approximately two-thirds of a kilometre west of Pillar Point, $250 \mathrm{ft}$ north, $400 \mathrm{ft}$ east of NW cor. sec. 3, T. 31 N., R. 11 W., Pysht 15-minute quadrangle. Collected by W. O. Addicott and J. E. Pearl, 1971.

M5878. Same as M4049. Collected by W. O. Addicott, 1973.

M5879. Same as M4050. Collected by W. O. Addicott, 1973.

M5885. Intertidal zone exposure at base of sandy beach approximately $3 \mathrm{k}$ west of Pillar Point, 2,800 ft north, 3,300 ft east of SW cor. sec. 32 , T. 32 N., R. 11 W., Pysht 15minute quadrangle. Collected by W. O. Addicott and J. E. Pearl, 1973

M5886. Prominent point about one-half a kilometre east of Slip Point, $5,100 \mathrm{ft}$ north, $1,400 \mathrm{ft}$ west of SE cor. sec. 21, T. 32 N., R. 12 W., Pysht 15-minute quadrangle. Collected by W. O. Addicott, 1973.

M6029. Intertidal exposure of massive, Vertipecten-bearing sandstone at base of gravel beach at Slip Point Lighthouse compound, $300 \mathrm{ft}$ west, $4,250 \mathrm{ft}$ north of SE cor. of Clallam Bay 15-minute quadrangle. Approximately 130 $\mathrm{m}$ above the base of the formation. Collected by W. O. Addicott, 1973.

M6373. Intertidal zone exposure of 1-m-thick fossil bed $27 \mathrm{~m} \mathrm{~N} .26^{\circ}$ W. of M4049 and $12 \mathrm{~m}$ stratigraphically above M4049, in N1/2N1/2SE1/4 sec. 32 , T. 32 N., R. 12 W., Pysht 15-minute quadrangle. Approximately $230 \mathrm{~m}$ above the base of the 
formation. Collected by W. O. Addicott and J. W. Miller, 1974.

M6375. Large blocks of silty sandstone at base of cliff about $100 \mathrm{~m}$ west of giant talus pile $550 \mathrm{ft}$ north, $1,850 \mathrm{ft}$ east of SW cor. sec. 23 , T. 32 N., R. 12 W., Pysht 15-minute quadrangle. Lowest $20-40 \mathrm{~m}$ of the formation. Collected by W. O. Addicott and J. W. Miller, 1974.

\section{Stanford University localities}

[These descriptions are from the Stanford University locality register. Published descriptions in Arnold and Hannibal (1913, p. 589) are different in some respects]

NP89. Oligocene-Miocene, Monterey basal sandstone, seacliffs eastward from Slip Point for half a mile, Clallam Bay, Wash. Collected by A. B. Reagan and Harold Hannibal, 1911, 1912. USGS localities M4051 and M5886 are from the same area.

NP160. Monterey sandstone, seacliffs at Pillar Point, straits east of Clallam Bay, Wash. Collected by Harold Hannibal, 1912. USGS localities M4675, M4683, and M4684 are from the same area.

NP161. Monterey shale and sandstone, seacliffs $1 \frac{112}{2}$ miles west of Pillar Point, Clallam Bay, Wash. Collected by Harold Hannibal, 1912. USGS localities M4049 and M4050 are from the same area; the assemblage from M4049 most closely resembles that of NP161.

NP162. Monterey carbonaceous sandstone, seacliffs at coal mine, straits east of Clallam Bay, Wash. Collected by Harold Hannibal, 1912. Probably stratigraphically higher than M4678 which is from the same area.

NP163. Oligocene-Miocene, Monterey shaly sandstone east of Clallam Bay, Wash. Collected by Harold Hannibal, 1912. Probably same locality as M4681.

\section{Washington University (Seattle) localities}

UW270. Cliff, south shore of Strait of Juan de Fuca, Clallam County, sec. 23, T. 31 N., R. 12 W. (Weaver, 1942).

UW490. Very shaly sandstone in cliff, beach section $11,000 \mathrm{ft}$ southeast of Slip Point and 13,000 ft due east of the town of Clallam Bay, Clallam County, NE $1 / 4 \mathrm{SE}^{1 / 4}$ sec. 22 , T. 32 N., R. 12 W. (Weaver, 1942).

\section{REFERENCES CITED}

Addicott, W. O., 1965, Miocene macrofossils of the southeastern San Joaquin Valley, California, in Geological Survey research 1965: U.S. Geol. Survey Prof. Paper 525-C, p. C101-C109, 4 figs.

1966a, Late Pleistocene marine paleoecology and zoogeography in central California: U.S. Geol. Survey Prof. Paper 523-C, p. C1-C20, pls. 1-4.

-1966b, New Tertiary marine mollusks from Oregon and Washington: Jour. Paleontology, v. 40, no. 3, p. 635-646, 3 pls. 1967, Zoogeographic evidence for later Tertiary lateral slip on the San Andreas fault, California: U.S. Geol. Survey Prof. Paper 593-D, p. D1-D12.

1969, Tertiary climatic change, in the marginal northeastern Pacific Ocean: Science, v. 165, no. 3893, p. 583-586.

1970a, Miocene gastropods and biostratigraphy of the Kern River area, California: U.S. Geol. Survey Prof. Paper 642, 174 p., 21 pls.

1970b, Latitudinal gradients in Tertiary molluscan faunas of the Pacific coast: Palaeogeography, Palaeoclimatology, Palaeoecology, v. 8 , no. 4 , p. 287-312.
1972, Provincial middle and late Tertiary molluscan stages, Temblor Range, California, in Symposium on Miocene biostratigraphy of California: Soc. Econ. Paleontologists and Mineralogists, Pacific Section, Bakersfield, Calif., March 1972, p. 1-26, pls. 1-4.

1973, Oligocene molluscan biostratigraphy and paleontology of the lower part of the type Temblor Formation, California: U.S. Geol. Survey Prof. Paper 791, 48 p., 9 pls.

-1974, Giant pectinids of the eastern North Pacific margin: significance in Neogene zoogeography and chronostratigraphy: Jour. Paleontology v. 48, no. 1, p. 180-194, 2 pls.

1975, Provincial age and correlation of the Clallam Formation, northwestern Washington: Geol. Soc. America Abs. with Programs, v. 7, no. 3, p. 289.

1976, Neogene molluscan stages of Oregon and Washington, in Wornardt, W. W., ed., Symposium on the Neogene of the Pacific Coast: Soc. Econ. Paleontologists and Mineralogists, Pacific Section, San Francisco, Calif., April, 1976 (in press).

Addicott, W. O., Kanno, Saburo, Sakamoto, Kenji, and Miller, D. J., 1971, Clark's Tertiary molluscan types from the Yakataga District, Gulf of Alaska, in Geological Survey research 1971: U.S. Geol. Survey Prof. Paper 750-C, p. C18-C33, 6 figs.

Allison, R. C., and Addicott, W. O., 1976, The North Pacific Miocene record of Mytilus (Plicatomytilus), a new subgenus (Bivalvia): U.S. Geol. Survey Prof. Paper 962, 66 p., 3 pls.

Anderson, F. M., 1905, A stratigraphic study in the Mount Diablo Range of California: California Acad. Sci. Proc., ser. 3, v. 2, p. $155-248,23$ pls.

Anderson, F. M., and Martin, Bruce, 1914, Neocene record in the Temblor Basin, California, and Neocene deposits of the San Juan district, San Luis Obispo County: California Acad. Sci. Proc., ser. 4, v. 4, no. 3, p. 15-112, pls. 1-10.

Armentrout, J. M., 1975, Molluscan biostratigraphy of the Lincoln Creek Formation, southwest Washington, in Weaver, D. W., and others, eds., Paleogene symposium and selected technical papers: Am. Assoc. Petroleum Geologists, Soc. Econ. Paleontologists and Mineralogists, Soc. Econ. Geophysicists, Pacific Sections, 1975 Annual Mtg., Long Beach, Calif., p. 14-48.

Arnold, Ralph, 1905, Coal in Clallam County, Washington: U.S. Geol. Survey Bull. 260, p. 413-421.

1906, Geological reconnaissance of the coast of the Olympic Peninsula, Washington: Geol. Soc. America Bull., v. 17, p. 451468, 1 map.

1907, New and characteristic species of fossil mollusks from the oil-bearing Tertiary formations of Santa Barbara County, California: Smithsonian Inst. Misc. Colln., v. 50, pt. 4, no. 1781, p. $419-447$, pls. $50-58$.

1908, Descriptions of new Cretaceous and Tertiary fossils from the Santa Cruz Mountains, California: U.S. Natl. Mus. Proc., v. 34 , no. 1617 , p. $345-390$, pls. $31-37$.

1909, Paleontology of the Coalinga district, Fresno and Kings Counties, California: U.S. Geol. Survey Bull. 396, 173 p., 30 pls. [1910].

Arnold, Ralph, and Hannibal, Harold, 1913, The marine Tertiary stratigraphy of the north Pacific Coast of America: Am. Philos. Soc. Proc., v. 52, no. 212 , p. 559-605.

Bernard, F. R., 1972, The genus Thyasira in western Canada (Bivalvia: Lucinacea): Malacologia, v. 11, no. 2, p. 365-389.

Brown, R. D., Jr., and Gower, H. D., 1958, Twin River formation (redefinition), northern Olympic Peninsula, Washington: Am. Assoc. Petroleum Geologists Bull., v. 42, no. 10, p. 2492-2512.

Brown, R. D., Snavely, P. D., Jr., and Gower, H. D., 1956, Lyre Formation (redefinition), Northern Olympic Peninsula, Washington: Am. Assoc. Petroleum Geologists Bull., v. 40, no. 1, p. 94-107. 
Clark, B. L., 1915, Fauna of the San Pablo Group of middle California: California Univ. Pubs., Dept. Geology Bull., v. 8, no. 22, p. 385-572, pls. 42-71.

1918, The San Lorenzo series of middle California: California Univ. Pubs., Dept. Geology Bull., v. 11, no. 2, p. 45-234, pls. 3-24.

1925, Pelecypoda from the marine Oligocene of western North America: California Univ. Pubs., Dept. Geol. Sci. Bull., v. 15, no. 4, p. $69-136$, pls. $8-22$.

1932, Fauna of the Poul and Yakataga Formations (upper Oligocene) of southern Alaska: Geol. Soc. America Bull., v. 43, p. 797-846, pls. 14-21.

Clark, B. L., and Arnold, Ralph, 1923, Fauna of the Sooke Formation, Vancouver Island, with description of a new coral by $\mathbf{T}$. Wayland Vaughan: California Univ. Pubs., Dept. Geol. Sci. Bull., v. 14 , no. 5 , p. $123-234$, pls. $15-42$.

Clark, J. C., 1968, Correlation of the Santa Cruz Mountains Tertiary-implications for San Andreas History, in Dickinson, W. R., and Grantz, A. A., Proceedings on Conference on Geologic Problems of San Andreas Fault System: Stanford Univ. Pubs., Univ. Ser., Geol. Sci. v. 11, p. 166-180.

Coan, E. V., 1971, The northwest American Tellinidae: Veliger, v. 14, supplement, p. 1-63, pls. 1-12.

Conrad, T. A., 1837, Description of new marine shells from upper California, collected by Thomas Nutall, Esq.: Acad. Nat. Sci. Philadelphia Jour., v. 7, pt. 2, p. 227-268, pls. 17-20.

1848, Fossil shells from Tertiary deposits on Columbia River, near Astoria [Oregon]: Am. Jour. Sci., ser. 2, v. 5, p. 432-433, 14 figs. [Reprinted in Dall, 1909, U.S. Geol. Survey Prof. Paper 59, p. 150-151.]

1849, Fossils from northwestern America, in Dana, J. D., U.S. Explor. Exped. ***, 1838-1842, under the command of Charles Wilkes: v. 10, app. p. 722-728; atlas, pls. 17-21. [Text reprinted in Dall, 1909, U.S. Geol. Survey Prof. Paper 59, p. 152-156.]

-1855 , Notes on the Miocene and post-Pliocene deposits of California with descriptions of two new fossil corals: Acad. Nat. Sci. Philadelphia Proc., v. 7, p. 441.

1865, Catalogue of the older Eocene shells of Oregon: Am. Jour. Conchology, v. 1, p. 150-154.

Dall, W. H., 1890-1903, Contributions to the Tertiary fauna of Florida, with especial reference to the Miocene silex beds of Tampa and the Pliocene beds of the Caloosahatchie River: Wagner Free Inst. Sci. Trans., v. 3, pts. 1-6, 1654 p., 60 pls. 1890, pt. 1 , p. $1-200$, pls. $1-12.1892$, pt. 2 , p. 201-473, pls. $13-22.1895$, pt. 3 , p. $474-570.1898$, pt. 4 , p. $571-947$, pls. $23-35.1900$, pt. 5 , p. $948-1218$, pls. $37-47.1903$, pt. 6 , p. $1219-1654$, pls. $48-60$.

1909, Contributions to the Tertiary paleontology of the Pacific Coast, I. The Miocene of Astoria and Coos Bay, Oregon: U.S. Geol. Survey Prof. Paper 59, 278 p., 23 pls.

1916, Diagnoses of new species of marine bivalve mollusks from the northwest coast of America in the collection of the United States National Museum: U.S. Natl. Mus. Proc., v. 52, no. 2183 , p. 393-417.

_ 1922 , Fossils of the Olympic Peninsula [Washington]: Am. Jour. Sci., ser. 5, v. 4, p. 305-314.

Dibblee, T. W., Jr., 1966, Geology of the Palo Alto quadrangle, Santa Clara and San Mateo Counties, California: California Div. Mines Map Sheet 8.

Durham, J. W., 1937, Gastropods of the family Epitoniidae from Mesozoic and Cenozoic rocks of the West Coast of North America, including one new species by F. E. Turner and one by R. A. Bramkamp: Jour. Paleontology, v. 11, no. 6, p. 479-512, pls. 56-57.

1944, Megafaunal zones of the Oligocene of northwestern Washington: California Univ. Pubs., Dept. Geol. Sci. Bull., v. 27, no. 5, p. 101-211, pls. 13-18.

Eaton, J. E., Grant, U. S., and Allen, H. B., 1941, Miocene of Caliente Range and environs, California: Am. Assoc. Petroleum Geologists Bull., v. 25, no. 2, p. 193-262, 9 pls.

Etherington, T. J., 1931, Stratigraphy and fauna of the Astoria Miocene of southwest Washington: California Univ. Pubs., Dept. Geol. Sci. Bull., v. 20, no. 5, p. 31-142, 14 pls.

Faustman, W. F., 1964, Paleontology of the Wildcat Group at Scotia and Centerville Beach, California: California Univ. Pubs. Geol. Sci., v. 41 , no. 2 , p. $97-160,3$ pls.

Fitch, J. E., 1953, Common marine bivalves of California: California Dept. Fish and Game, Fish Bull. 90, 102 p., 63 figs.

Gabb, W. M., 1866, Tertiary invertebrate fossils: California Geol. Survey, Paleontology, v. 2, sec. 1, pt. 1, p. 1-38, pls. 1-13.

1869, Tertiary invertebrate fossils: California Geol. Survey, Paleontology, v. 2, Cretaceous and Tertiary fossils, sec. 1, pt. 2, p. 39-63, pls. $14-18$.

Gilman, S. C., 1896, The Olympic Country: Natl. Geog. Mag., v. 7, p. 133-140.

Gladenkov, Y. B., 1972, Neogene of Kamchatka (problems of biostratigraphy and paleontology): Moscow, Publishing Office "Nauka", Trans., v. 214, 251 p., 8 pls.

_ 1974, The Neogene Period in the subarctic sector of the Pacific, in Herman, Yvonne, ed., Marine geology and oceanography of the Arctic Seas: New York, Springer-Verlag, p. 1-416.

Gower, H. D., 1960, Geologic map of the Pysht quadrangle, Washington: U.S. Geol. Survey Geol. Quad. Map GQ-129, scale $1: 62,500$

Grant, U. S., 4th, and Gale, H. R., 1931, Catalogue of the marine Pliocene and Pleistocene Mollusca of California: San Diego Soc. Nat. History Mem., v. 1, 1036 p., 32 pls., 15 figs.

Habe, Tadashige, 1964, Shells of the western Pacific in color, v. 2: Osaka, Japan, Joikusha, 233 p., 66 pls.

Hanna, G D., 1924, Rectifications of nomenclature: California Acad. Sci. Proc., ser. 4, v. 13, no. 8, p. 151-186.

Heacock, R. L., and Boyd, H. A., 1954, Fossil foraminifera from the upper part of the Nye Formation, Lincoln County, Oregon: Oregon Acad. Sci. Proc., v. 3, p. 35.

Hickman, C. J. S., 1969, The Oligocene marine molluscan fauna of the Eugene Formation in Oregon: Oregon Univ. Mus. Nat. History Bull. 16, 112 p., 14 pls.

Howe, H. V., 1926, Astoria: Mid-Tertic type of Pacific coast: PanAm. Geologist, v. 45, p. 295-306.

Il'ina, A. P., 1963, Mollyuski Neogena Kamchatki [Neogene mollusks of Kamchatka]: Vses. Neft. Nauchno-Issled. Geol.-Razved. Inst. Trudy (VNIGRI), v. 202, p. 1-242, pls. 1-54.

Kanno, Saburo, 1960, Tertiary system of the Chichibu Basin, Saitama Prefecture, Central Japan, part II, Palaeontology: Japan Soc. Promotion Sci., Uneno, Tokyo, p. 123-396, pls. 31-51. -1970 , The ecological significance of Thyasira bisecta Conrad, Nautilus, v. 84, no. 3, p. 96-101.

1971, Tertiary molluscan fauna from the Yakataga District and adjacent areas of southern Alaska: Palaeont. Soc. Japan Spec. Papers no. 16, 154 p., 18 pls.

Kanno, Saburo, Ohara, S., and Kaiteya, H., 1968, The "Ashai Fauna" from the Miocene formation developed near the Asahi Coal-Mine, Iwamizawa City, Hokkaido [Japan]: Tokyo Univ. Education Sci. Rept., sec. C, v. 10, no. 94, p. 1-14, pls. 1, 2.

Keen, A. M., with the assistance of McLean, J. H., 1971, Sea shells of tropical West America, marine mollusks from Baja California to Peru: Stanford, Calif., Stanford Univ. Press, 22 pls.

Kern, J. P., 1973, Early Pliocene marine climate and environment of the Eastern Ventura basin, southern California: California Univ. Pubs. Geol. Sci., v. 96, 117 p.

Kleinpell, R. M., 1938, Miocene stratigraphy of California: Tulsa, 
Okla., Am. Assoc. Petroleum Geologists, 450 p.

Loel, Wayne, and Corey, W. H., 1932, The Vaqueros formation, Lower Miocene of California; [pt.] 1, Paleontology: California Univ. Pubs., Dept. Geol. Sci. Bull., v. 22, no. 3, p. 31-140, pls. 4-65.

McCormick, Lavon, and Moore, R. C., 1969, Outline of classification [Bivalvia] [in Newell, N. D., Classification of Bivalvia (p. N205-N224)], in Moore, R. C., ed., and others (22), Bivalvia, pt. $\mathrm{N}$, Treatise on Invertebrate Paleontology: Lawrence, Kansas, Kansas Univ. Press, v. 1, p. N218-N222.

Makiyama, J., 1934, The Asagaian molluses of Yotukura and Matchgar: Kyoto Univ. College Sci. Mem., Ser. B, v. 10, no. 2, art. 6, p. 121-167, pls. 3-7.

Marincovich, L. N., Jr., 1973, Neogene to recent Naticidae (Mollusca: Gastropoda) of the eastern Pacific: Southern California Univ., unpub. Ph.D. thesis, 385 p., 3 pls.

Meek, F. B., 1864, Check list of the invertebrate fossils of North America, Miocene: Smithsonian Misc. Colln., v. 4, Pub. 183, p. $1-32$.

Merriam, C. W., 1941, Fossil Turritellas from the Pacific coast region of North America: California Univ. Pubs., Dept. Geol. Sci. Bull., v. 26 , no. 1 , p. 1-214, pls. 1-41.

Merriam, J. C., 1897, New species of Tertiary mollusks from Vancouver Island [British Columbia]: Nautilus, v. 2, p. 64-65.

Miller, A. K., 1947, Tertiary nautiloids of the Americas: Geol. Soc. America Mem. 23, 234 p., 100 pls.

Miller, D. J., 1971, Geologic map of the Yakataga district, Gulf of Alaska Tertiary Province, Alaska: U.S. Geol. Survey Misc. Geol. Inv. Map I-610, scale 1:125,000, p. 1-5.

Moore, E. J., 1963, Miocene mollusks from the Astoria Formation in Oregon: U.S. Geol. Survey Prof. Paper 419, 109 p., 33 pls.

Newell, N. D., 1965, Classification of the Bivalvia: Am. Mus. Novitates, no. $2206,25 \mathrm{p}$.

Packard, E. L., 1916, Mesozoic and Cenozoic Mactrinae of the Pacific Coast of North America: California Univ. Pubs., Dept. Geology Bull., v. 9, no. 16, p. 261-360, pls. 12-35.

Parker, Pierre, 1949, Fossil and Recent species of the pelecypod genera Chione and Securella from the Pacific Coast: Jour. Paleontology, v. 23 , no. 6 , p. 577-593, pls. 89-95.

Parker, R. H., 1963, Zoogeography and ecology of some macroinvertebrates, particularly mollusks, in the Gulf of California and the continental slope off Mexico: Vidensk, Medd. fra Dansk Naturh. Foren., v. 126, 178 p., 15 pls.

Pilsbry, H. A., and Sharp, B., 1898, Fossil Scaphopoda: Manual of Conchology, ser. 1, v. 17, app. A, p. 197-240.

Powell, A. W. B., 1966, The molluscan families Speightiidae and Turridae: Auckland Inst. and Museum Bull. no. 5, 184 p., 23 pls.

Quayle, D. B., 1973, Intertidal bivalves of British Columbia: British Columbia Prov. Mus. Handbook no. 17, 104 p., illus.

Rau, W. .W., 1964, Foraminifera from the northern Olympic Peninsula, Washington: U.S. Geol. Survey Prof. Paper 374-G, p. G1G33.

1967, Geology of the Wynoochee Valley quadrangle, Grays Harbor County, Washington: Washington Div. Mines and Geology Bull. 56, $51 \mathrm{p}$.

-1973, Geology of the Washington coast between Point Grenville and the Hoh River: Washington Dept. Nat. Resources, Geology and Earth Resources Div. Bull. 66, 58 p.

Reagan, A. B., 1909, Some notes on the Olympic Peninsula Washington: Kansas Acad. Sci. Trans., v. 22, p. 131-238, 6 pls.

Reinhart, P. W., 1943, Mesozoic and Cenozoic Arcidae from the Pacific slope of North America: Geol. Soc. America Spec. Paper 47 , p. $1-117$, pls. $1-15$, 3 figs.

Schenck, H. G., 1926, Cassididae of western America: California Univ. Pubs., Dept. Geol. Sci. Bull., v. 16, no. 4, p. 69-98, pls.
$12-15$.

1931, Cephalopods of the genus Aturia from western North America: California Univ. Pubs., Dept. Geol. Sci. Bull., v. 19, no. 19, p. $435-490$, pls. $66-78$.

1936, Nuculid bivalves of the genus Acila: Geol. Soc. America Spec. Paper 4, 149 p., 18 pls., 15 figs., tables 1-17.

Slodkewtisch, W. S., 1938, Tertiary Pelecypoda from the Far East, v. 10, pt. 2: USSR Acad. Sci., Paleont. Inst., Paleontology of USSR, v. 10 , pt. 3 , fasc. 19,275 p., 106 pls.

Smith, A. G., and Gordon, Mackenzie, Jr., 1948, The marine mollusks and brachiopods of Monterey Bay, California, and vicinity: California Acad. Sci. Proc., ser. 4, v. 26, no. 8, p. 147-245, pls. 3, 4.

Snavely, P. D., Jr., MacLeod, N. S., and Rau, W. W., 1969a, Geology of the Newport area, Oregon [pt. I, Geologic sketch]: Ore-Bin, v. 31 , no. 2, p. 25-48.

$1969 \mathrm{~b}$, Geology of the Newport area, Oregon [pt. II, Geologic fieldtrip guide]: Ore-Bin, v. 31, no. 3, p. 49-71.

Snavely, P. D., MacLeod, N. S., Wagner, H. C., and Rau, W. W., 1976, Geology of the Yaquina and Toledo quadrangles, Lincoln County, Oregon: U.S. Geol. Survey Misc. Inv. Map I-867, scale $1: 62,500$.

Snavely, P. D., Jr., Rau, W. W., and Wagner, H. C., 1964, Miocene stratigraphy of the Yaquina Bay area, Newport, Oregon: Ore Bin, v. 26, no. 8, p. 133-151.

Soot-Ryen, Tron, 1955, A report on the family Mytilidae (Pelecypods): Allan Hancock Pacific Exped., v. 20, no. 1, 175 p., pls. $1-10$, figs. $1-78$.

Stanton, R. J., Jr., and Dodd, J. R., 1970, Paleoecologic techniquescomparison of faunal and geochemical analyses of Pliocene paleo-environments, Kettleman Hills, California: Jour. Paleontology, v. 44, no. 6, p. 1092-1121.

Stirton, R. A., 1960, A marine carnivore from the Clallam Miocene formation, Washington, its correlation with nonmarine faunas: California Univ. Pubs. Geol. Sci., v. 36, no. 7, p. 345-368.

Talmadge, R. R., 1972, Notes on some California Mollusca: geographical ecological and chronological distribution: Veliger, v. 14, no. 4, p. 411-413.

Taylor, D. W., and Sohl, N. F., 1962, An outline of gastropod classification: Malacologia, v. 1 , no. 1 , p. 7-32.

Tegland, N. M., 1929, Correlation and affinities of certain species of Pitaria: California Univ. Pubs., Dept. Geol. Sci. Bull., v. 18, no. 10, p. 275-290, 2 pls.

-1933, The fauna of the type Blakeley upper Oligocene of Washington: California Univ. Pubs., Dept. Geol. Sci. Bull., v. 23, no. 3, p. 81-174, pls. 2-15.

Turner, D. L., 1970, Potassium-argon dating of Pacific coast Miocene foraminiferal stages, in Bandy, O. L., ed., Radiometric dating and paleontologic zonation: Geol. Soc. America Spec. Paper 124, p. 91-129.

Valentine, J. W., 1966, Numerical analysis of marine molluscan ranges on the extratropical northeastern Pacific shelf: Limnology and Oceanography, v. 11, no. 2, p. 198-211.

Van Winkle, Katherine E., 1918, Paleontology of the Oligocene of the Chehalis Valley, Washington: Washington Univ. Pub. Geology, v. 1 , no. 2 , p. $69-97$.

Wagner, H. C., 1967, Preliminary geologic map of the Raymond quadrangle, Pacific Co., Washington: U.S. Geol. Survey open-file report, scale, 1:62,500.

Weaver, C. E., 1912, A preliminary report on the Tertiary paleontology of western Washington: Washington Geol. Survey Bull. 15, 80 p., 15 pls.

1916a, The Tertiary formations of western Washington: Washington Geol. Survey Bull. 13, 327 p.

1916b, Tertiary faunal horizons of western Washington: Washington Univ. Pub. Geology, v. 1, no. 1, p. 1-67, pls. 1-5. 
1937, Tertiary stratigraphy of western Washington and northwestern Oregon: Washington Univ. Pub. Geology, v. 4, $266 \mathrm{p}$.

1942, Paleontology of the marine Tertiary formations of Oregon and Washington: Washington Univ. [Seattle] Pubs. Geology, v. 5 , pts. $1-3,789$ p., 104 pls.

Weaver, C. E., Chm., and others (20), 1944, Correlation of the marine Cenozoic formations of western North America: Geol. Soc. America Bull., v. 55, no. 5, p. 569-598.
Wiedey, L. W., 1928, Notes on the Vaqueros and Temblor formations of the California Miocene with descriptions of a new species: San Diego Soc. Nat. History Trans., v. 5, no. 10, p. 95-182, pls. 9-21.

Wolfe, E. W., and McKee, E. H., 1972, Sedimentary and igneous rocks of the Grays River quadrangle, Washington: U.S. Geol. Survey Bull. 1335, 70 p.

Zinsmeister, W. J., 1974, A new interpretation of thermally anomalous molluscan assemblages of the California Pleistocene: Jour. Paleontology, v. 48 , no. 1 , p. 84-94. 



\section{INDEX}

[Italic page numbers indicate major references]

\section{A}

Page

abrupta, Panope
Panopea
Acila
$\quad$ conradi
gettysburgensis

albaria, Macoma Spisula _-__._._._. 4, 5, 14, 15,31, pls. 6, 7 goodspeedi, Spisula _...___ 5, 10, 14,31, pls. 6,7

alta, Metis

Amauropsis oregonensis

Anadara devincta _._._._._._. $5,12,14,28, \mathrm{pl} .5$

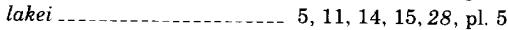
s.s submontereyana

Ancistrolepis clarki ...._..._... 23 clarki teglandae _.._-_._._. 23 rearensis _-___ $5,10,14,15,16,17,23, \mathrm{pl} .3$ anglonana, Molopophorus ...-. 24 angustata, Aturia angustifrons, Katherinella _._._. 4, 6, 14, 15,33, pl. 8 Venus, (Chione) --_..- 4 annulata, Lucinoma ............. 18, 19 Antigona olympidea antiselli, Thesbia

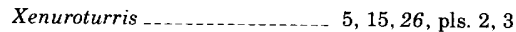
apta, Echinophoria _._._._. 23 Liracassis _-_._- 17

Archarax dalli _._._._. $5,10,11,13,14,16,28$, pl. 3 ventricosa -... 28 willapaensis _......... 28

Arcidae - 28 arctata, Macoma …___._. 3, 4, 6, 14,32, pl. 7 Tellina -......... 3,4 juana, Tellina Armentrout, J. M., cited _.... 16 Arnold, Ralph, eited _._ 6,7 arnoldi, Macoma _-_._. 32, pl. 7 ethringtoni, Katherinella astori, Macoma _........ 6, 10, 14, 19,32, pl. 7 Astoria, Oreg
Astoria Formation age benthonic foraminifera contact fauna, Newportian middle Miocene ........ 18 molluscan fauna _..._.___._._._. 12, 16, 17 Miocene fauna _-_ 3,16 Newport Embayment, Oreg - Oregon _._._._. $3,10,12,16,17,20,21$ $25,26,27,28,29,31,33,34,35$ southwestern Washington_..._._. $3,10,17$, $23,24,26,27,28,29,31,35$

type area
Page
Aturia
angustata

B

Baja California, Mexico - 20

Bakersfield, Calif ---- 35

Barker's Ranch fauna

Bathymetry -...

Biostratigraphy -............. 6

birchi, Cancellaria _._____ $5,15,25, \mathrm{pl} .2$

bisecta, Conchocele -... 30

Blakeley Formation, Washington _...____ 25, 30

Blakeley Stage $6,13,16,18,29,31$

British Columbia _........ 13

brota, Macoma -

Bruclarkia

oregonensis ___________._ 4, 5, 14,23, pl. 2 yaquinana

Buccinum clallamensis _...
bulbosus, Teredo

C

California, Coast Ranges formaminiferal correlation --_-_middle Miocene strata

Temblor Stage _._........... 12

Vaqueros Stage _._. 12,13

calkinsi, Nuculana _.________- 5, 14, 15,27, pl. 3

Calyptraea sp ...

Calyptraeidae _........ 21

Canada, western, provincial molluscan stages _._._- 4

Cancellaria._-_._._. 19 birchi___ $5,15,25, \mathrm{pl} .2$

oregonensis -_._........ 5, 15,25,26, pl. 2

siletzensis _._._._______. $5,11,15,25, \mathrm{pl} .2$

simplex -

wynoocheensis _.......... 5, 12, 15,26, pl. 2

(Euclia) _......... 20

Cancellariidae ..... 25

Cape Yakataga, Alaska _..._...... 17

Cardiidae _. 30

Carditidae - 30

Carnivore, marine - 4

Cassididae -...-. 22

castor, Cyclocardia -_. 30

castrensis, Nucula (Acila) -

catilliformis, Spisula _._.___ 31

centiquadrata, Semicassis __________ 23

Cephalopods _._._. 6, 14,34

Cetacean

chehalisensis, Nuculana _..... 5, 12, 14, 27, pl. 3

Chione -... 34

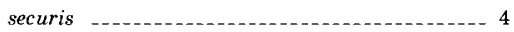
sp - .

(Chione) angustifrons, Venus _..._............... 4 clallamensis, Venus _._._._._. 4 olympidea, Venus _.

(Chlamys) fucanus, Pecten -_-_-_-_-_._- 4 wattsi morani, Pecten

Clallam Bay _._._. 1, 3, 6, 21, 30

Clallam coal mine

Clallam County, Washington

Washington, fossil localities

Clallam fauna, late early Miocene _._._._-_._. 20

Clallam Formation
Clallam Formation-Continued

benthonic foraminifera

contact

correlation -.... 2, $6,7,8,12$

depositional cycle -

depositional environment _............. 18, 20

exposures _._._.

fauna

Pillarian

faunal assemblages _..._._._. $10,11,12,18,19$

faunal hiatus .......... $9,10,16$

fossil localities .

fossils_._-_-_-_._-_. 6

lithology -.---.-- 1, 7

living species

marine carnivore - -

marine mollusks _-_._-_._ $1,2,3,10,15,17,18$

microfaunal boundary

Miocene assemblages -

Miocene boundary -...- 2

molluscan fauna ........................ 20

nomenclatorial history ................ 6, 7

Oligocene-Miocene boundary -

provincial chronostratigraphy _.............. 12

restricted species

stratigraphy -

thickness _............. 1, 7

type locality

type section - 18

unconformity

Washington _._.

clallamense, Epitonium _ـ 5,14,16,17,21, pl. 1

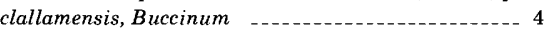

Pisania

Tellina --.- 4, 32, pl. 7

Trophosycon _-_.___._ 5, 14, 15, 23, pls. 1,2

Venus -.... 34, pl. 9 (Chione) -

clarki, Ancistrolepis _....... 23

Natica _-_____ 5, 14, 22, pl. 1

Priscofusus .................... 24

teglandae, Ancistrolepis

Clinocardium 30 nuttalli _._._______. 5, 11, 14, 19, 30, pls. 5,6 sookensis

yakatagense -......... 31

n. sp -

Coast Ranges, California

columbiana, Lucinoma _-_... 30

Conchocele bisecta -_._-_._-_._- 30 disjuncta_._...... $5,11,14,18,30, \mathrm{pl} .6$ condonana, Megasurcula _........... 27 condoni, Thracia -.............................. 34

conradi, Acila ......._._._._. 4, 5, 14, 27, pl. 3 Nucula (Acila) Solen

Coos Bay

Correlation foraminiferal molluscan

corrugata, Musashia _._._._._. 25

Crenella porterensis

Crepidula

praerupta _...__._. 5, 14,21, 22, pls. 1, 2

princeps

rostralis -

sookensis ...._.

sp _._. 


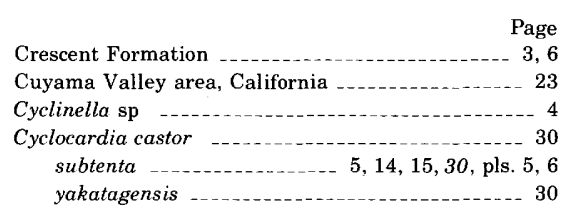

\section{D}

dalli, Archarax __.___ 5, 10, 11, 13, 14, 16, 28, pl. 3 Dentaliidae
Dentalium pseudonyma schencki _____._._._._._. $5,15,35, \mathrm{pl} .5$ substriatum

devincta, Anadara

Dibblee, T. W., Jr., cited

disjuncta, Conchocele _._____ 5, 11, 14, 18,30, pl. 6

Dosinia whitneyi _._._.............. $6,14,33, \mathrm{pl} .8$

East Clallam

East Twin River 30

Echinophoria apta _......... 23 apta zone _._. rex zone -....... 25, 34

elmana, Nuculana _.............. 5, 14, 27, pl. 3

emacerata, Tellina _._____ 4, 6, 14, 15,31, pl. 7

ensifera, Securella _.___. 4, 6, 14, 15, 33, pl. 9

Eocene-Miocene depositional cycle eparchis, Nuculana _-_._._._._._._._. 27

Epitoniidae -_.

Epitonium clallamense _._._-_. 5, 14, 16, 17, 21, pl. 1 equilateralis, Spisula ethringtoni, Katherinella arnoldi _._... 33 Euclia

(Euclia), Cancellaria _._. 20

\section{F}

Felaniella (30 parilis -_... 14, 30 sp -

Ficidae - .

Ficus - 19,20 modesta__-___ $5,14,23, \mathrm{pl} .1$ filosa, Trochita _... 21

flagleri, Macoma

Foraminifera, benthonic __-_ $2,4,12,13,16,18,20,27$ Jewett Sand -...- 13 Luisian _... Relizian _._. 27 Saucesian _. Fossil, bathymetric index -. 19 Fossil localities, Clallam County, Washington _-_- 35 Clallam Formation -... 35 Stanford University ....... 36 stratigraphic sequence _._._._. U.S.G.S., Menlo Park register _._. _ 8, 9, 11, 35 Washington University (Seattle)

Fossil species, Oregon Washington _-_... 10

Fossils, Astoria, Oreg _. 15 index species _........ 13 preservation restricted species _._._._._. 10, 11 zonal index species - 10

Freeman Silt

fucanus, Pecten (Chlamys)

Vertipecten

Fusinidae -17, 27, 29, pl. 4

Fusinus hannibali

G

Gastropod fauna

. 3

Gastropods -

generosa, Panopea
Page
geniculus, Priscofusus gettysburgensis, Acila ....... 17 gibbosus, Saxidomus gibbosus, Saxidomus Glycymerididae

Glycymeris _- 28 sp goodspeedi, Spisula albaria Gower, H. D., cited _._._. 9, 24 goweri, Priscofusus _-__._._._. 4, 15, 20, 24, 25, pl. 2 graciosana, Ophiodermella _-.._-_._- 26 Grays Harbor basin, Washington _._._._....... 27 Grays River quadrangle, southwestern

Washington _... 18, 26 Gulf of Alaska Miocene fauna ...................... 2, 17, 21

\section{$\mathrm{H}$}

Hannibal, Harold, cited hannibali, Fusinus

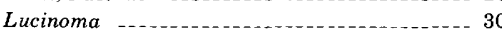
Priscofusus _._._._._._._....._._._._. 24, 25 Spisula _.____ 5, 10,13,14,16,31, pl. 6 Hercoglossidae -................ 34 Hiatellidae Hoh Formation ......... 27 Hoh rock assemblage _._._. 18, 30 Hokkaido, Japan _. Hoko River .

Honshu Island, Japan ........................ 32

\section{I}

iani, Semicassis impressa, Yoldia
indurata, Musashia Introduction

jamesae, Neverita ___._._._._._. 5, 14,22, pl. Japan -.... 18, 23

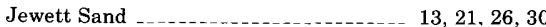
juana, Tellina arctata Juanian Stage _... 6, 16, 17, 18

Kamchatka _.._ 28, 29 Russia _._._. Katherinella angustifrons _._._._._ 4, 6, 14, 15,33, pl. 8 arnoldi ethringtoni . Keasey Formation kernianum, Trophosycon _............... 23 Kodiak Island, Alaska _._._. 33 Kuluven Suite

L

lakei, Anadara _-____ 5, 11, 14, 15, 28, pl. 5

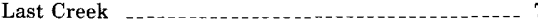
Lincoln Creek Formation _... 32 Lincoln Stage _....... 29 lipara, Macoma Liracassis apta _... Lucinidae _- 30

Lucinoma -..._. acutilineata $4,5,14,18,19,30, \mathrm{pl} .5$ annulata 18,19 columbiana hannibali (Lunatia) olympidii, Polynices _-_ 4 Lyre Formation

M

McCormick, Lavon, cited - 20 Macoma
Macoma-Continued

Page

albaria

$6,14,15,32, \mathrm{pl} .7$

arctata $3,4,6,14,32, \mathrm{pl} .7$

arnoldi _._-_. 32 , pl. 7

astori _-_ $6,10,14,19,32, \mathrm{pl} .7$

brota -...-... 19

flagleri _._-_-_- 33, pl. 8

lipara

nasuta --_-....... $6,12,14,15,19,20,33, \mathrm{pl} .8$

secta
sookensis -

twinensis __._. $6,10,11,13,14,16,32$, pls. 6,7

n. sp _..._. $6,14,15,16,20,33, \mathrm{pl} .8$

Mactra gibbsana _._._. 4, 31, pl. 7

Mactridae - 31

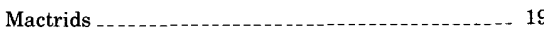

Marcia oregonensis

Matlockian Stage _-

matthewi, Molopophorus -_- 16, 24

Megasurcula

condonana ......... 27

wynoocheensis _....... $5,15,19,27, \mathrm{pl} .3$ spp

Metis alto

Mexico

middendorfi, Mytilus _-______- 13, 29

Miocene, index species _._._._. 27

Miocene assemblages _....................... 2

Miocene boundary _... 2 mollusks

Miocene fauna, Astoria Formation Gulf of Alaska.......... 3 modesta, Ficus Modiolus -...-...- 28 restorationensis _-_._-_. $5,11,14,15,20,28$, pl. 5 n. sp Molluscan fauna -.......... 3, 4, 7, 9, 10, 12, 18, 20

Molluscan paleontology ..................... 20

Molluscan province, late early Miocene _.______ 2, 3

Mollusks, depth ranges index species _......................... 13 living genera stratigraphic distribution _._._._._. 10, 11, 13, 15

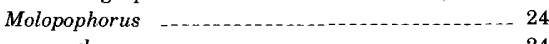

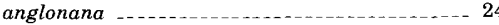
matthewi newcombei -_._-_._. $5,14,15,16,20,24$, pl. n. sp _....... 20,24, pl. 2

Monterey Formation ...................... 6

Montesano Formation, Weaver _-_._-_ 31

Moore, E. J., cited Moore, R. C., cited _..._. 20 morani, Pecten (Chlamys) wattsi muirensis, Ophiodermella _._._-_._._-_._-_._._. 26 Muricidae _............. 23

Musashia _._._._. 18 corrugata -indurata weateri -...-...- 17

Mytilidae 28

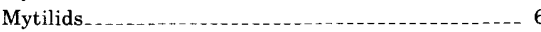

Mytilus _-_. 3, 19 middendorffi _......................... 13, 29 ochotensis 28,29 tichanovitchi n. $\mathrm{sp}_{\text {_. }}$

nasuta, Macoma ... . .

Natica clarki___ $5,14,22, \mathrm{pl} .1$ vokesi__._._._. $5,14,22$, pl. 1

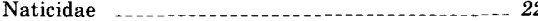
Neptuneidae Neverita _jamesae (Neverita) saxea, Polynices _-...-. newcombei, Molopophorus _- 5, 14, 15, 16, 20,24, pl. Newell, N. D., cited 


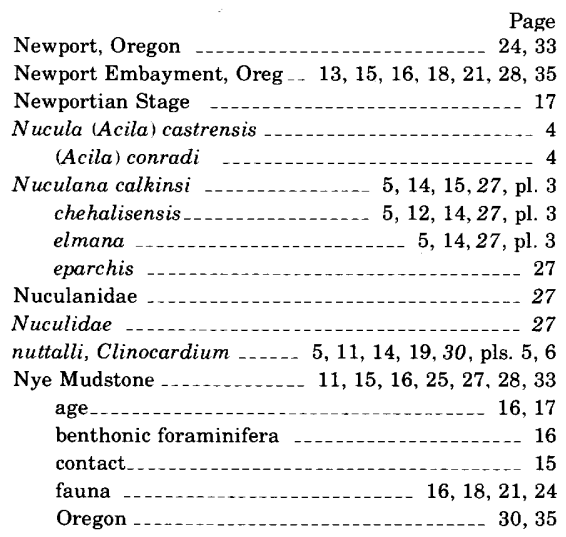

0

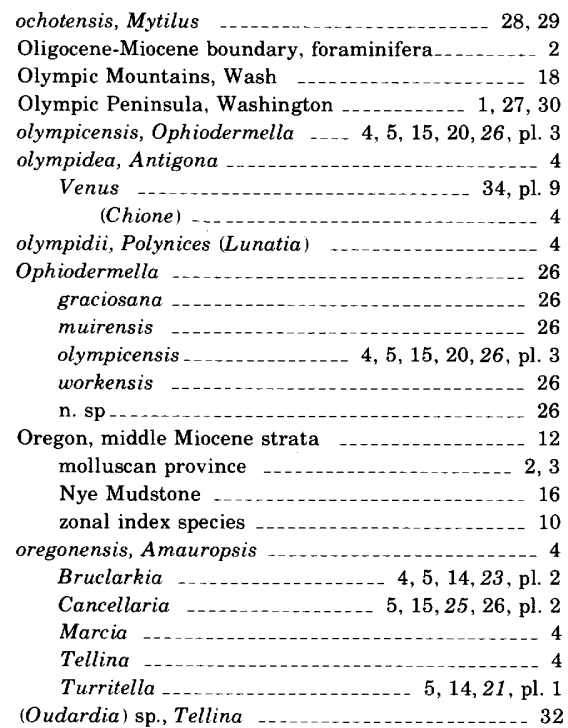

$\mathrm{P}$

Pacific coast …_. 19, 21, 23, 32 Pacific Northwest States, provincial molluscan stages

Page Mill Basalt

Paleoclimate

Paleoecology

Panamic molluscan province

Panope abrupta -

Panopea 18, 34 abrupta generosa
ramonensis n. sp parilis, Felaniella Patinopecten -..._..._. 15 propatulus _..._. 13, 16, 29 (Patinopecten) propatulus, Pecten _._._........ 4 patulus, Petunculus

Pecten (Chlamys) fucanus

Chlamys wattsi mor

-

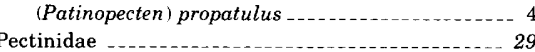

Pectinids ...... 6, 10, 13

Pelecypod fauna -........... 3

Pelecypods _... 4, 5, 10, 14, 15, 16, 20,27

Petunculus patulus..-

Phacoides acutilineatus _..._-_._- 4

Phalium -

Pillar Point _-_._ 3, 7, 8, 9, 12, 19, 21, 24, 25, 27, 28

Pillarian Stage
Pillarian Stage-Continued

type section

Pisania clallamensis

Polinices saxea victorianus _..._._._._._. $5,14,22$, pl.

Polynices (Lunatia) olympidii _._._. 4 (Neverita) saxea -........- 4

Porter Bluffs, Washington

porterensis, Crenella _._._. 29 Solamen _-_._. 29, pl. 4

Poul Creek

17

Poul Creek Formation,

Gulf of Alaska _............ 21, 23, 30, 31, 32, 34 molluscan assemblages -..... 17 praerupta, Crepidula _-_..... 5, 14,21, 22, pls. 1, 2 Previous faunal studies _.................... 3 princeps, Crepidula $a_{\ldots} \ldots \ldots, 10,14,21$, pl. 1

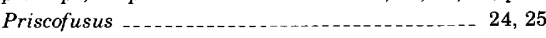
clarki ...... geniculus _..._._._. $5,11,15,16,24, \mathrm{pl} .2$ goweri _._._._._._. $4,15,20,24,25, \mathrm{pl} .2$ hannibali_........................ 24, 25 slipensis ______ $4,5,15,20,24$, pl. 2 stewarti__... $5,10,11,15,16,24,25, \mathrm{pl} .2$ n. sp propatulus, Patinopecten _-______._. 13, 16, 29

Pecten (Patinopecten) Provincial chronostratigraphy _._. 12 Provincial molluscan stages pseudonyma, Dentalium _.........- 4, 5, 15, 35, pl. 4 pyshtensis, Semicassis _._- 4, 5, 11, 14, 15, 20, 22, pl. 1

\section{Q}

quadrata, Venericardia subtenta 30

\section{$\mathrm{R}$}

ramonensis, Panopea _._._. 6, 14,34, pl. 9 Raymond quadrangle, Washington _......... 27

Reagan, A. B., cited _............ 3, 20

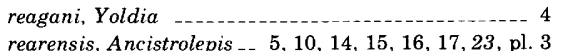
rearensis, Ancistrolepis _- 5, 10,14, 15, 16, 17, 23, pl. 3
Rectiplanes sp Reed Creek

References cited

Relizian Stage restorationensis, Modiolus _- 5, 11, 14, 15, 20,28, pl. 5 Rexithaerus -_..-_-_- 33 rostralis, Crepidula

San Francisco Bay region, California San Joaquin basin, Calif _._._._. 13, 23, 25, 26, 29 San Pablo Group . Saucesian Stage _............ 4, 16 foraminiferal assemblages ................. 27 saxea, Polinices ___ 22 Polynices (Neverita) - 4 Saxidomus gibbosus -......... 4 Scaphopods _._. $4,5,15,35$ Schenck, H. G., cited schencki, Dentalium ..._._. 5, 15, 35, pl. 5 Thracia_____ 6, 10,13,14,16,17,34, pl. 9 scopulosum, Sinum ___._._._ 4, 5, 14,22, pl. 1 scopulosus, Sigaretus secta, Macoma .

Securella $6,12,14,15,19,20,33$, pl. 8

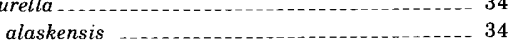
ensifera securis, Chione _-_.... 4 Seiku _. Semicassis _. 19, 23 aequisulcatum pyshtensis ___ $4,5,11,14,15,20,22, \mathrm{pl} .1$ centiquadrata
iani
Shark teeth

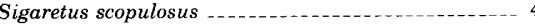
siletzensis, Cancellaria _..._._._. 5, 11, 15, 25, pl. simplex, Cancellaria _-_.___._. 5, 12, 15, 25, pl. 2 Sinum scopulosum _-_____._- 4, 5, 14,22, pl. 1 Slip Point _........ 3, 7, 8, 9, 12, 18, 19, 21, 23 $24,27,28,30,34$ slipensis, Priscofusus _______ 4, 5, 15, 20,24, pl. 2 Snavely, Parke D. Jr., cited _._. . . snavelyi, Solamen Sohl, N. F., cited _... 20 Solamen -- 18,29 porterensis _._._._._............. 29, pl. snavelyi _._._._._. $4,5,14,20,29, \mathrm{pl} .4$ Solemya Solemyidae-_-_._.

Solen -31 conradi _...... $6,14,31$, pl. 6 Solenidae Sooke Formation, fauna ookensis, Clinocardium Crepidula _. Macoma _._._. 6, 14,33, pls. 7, 8 Spisula _....___ 6, 10,13,14,16,31, pl. 6 Trochita ...-_-_-_._- 21 Species, index _....... 27 Spencer Creek, Lincoln County, Oreg _._._-_._- 25 spirata, Trochita _-_. Spirotropis washingtonensis _...-..-_...-...- 26 Spisula --.-.-.-.- 31 albaria ___._._._._._ 4, 5, 14, 15, 31, pls. 6,7 goodspeedi $5,10,14,31$, pls. 6,7 catilliformis _....... 31 equilateralis hannibali _..._._._._. $5,10,13,14,16,31$, pl. 6 sookensis _._. $6,10,13,14,16,31$, pl. 6 sp -

Stanford University collections stewarti, Priscofusus _-_ 5, 10, 11, 15, 16, 24, 25, pl. 2 submontereyana, Anadara --_-_-_.......- 28 substriata, Xylotrya

substriatum, Dentalium _._._................ 4 subtenta, Cyclocardia quadrata, Venericardia -...-...-. 30 supramontereyensis, Yoldia _-_._- 4, 5, 14, 19,27, pl. 3 Surian molluscan province

$\mathrm{T}$

Taylor, D. W., cited teglandae, Ancistrolepis clarki _._____________ 23 Tellina arctata arctata juana _._._..._._._._. 4, 32, pl. 7 clallamensis emacerata ........... 4, $6,14,15,31, \mathrm{pl} .7$ oregonensis (Oudardia) sp _._. 32 Tellinids_._.

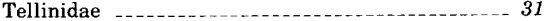

Temblor Formation -. Temblor Stage _... 16, 20 central California _._._._._._._._._. 12, 16, 17 tenuissima, Yoldia _._._..... 27 Teredo bulbosus _............ 4 sp _..... 4 Thesbia antiselli _._._._._._. 26

Thracia 18 condoni -_._- 34 schencki_.._-_._._. $6,10,13,14,16,17,34, \mathrm{pl} .9$ trapezoides _.........-. $6,14,15,18,19,34, \mathrm{pl} .9$

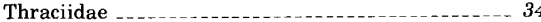
Thyasiridae -....- 30 tichanovitchi, Mytilus _- 5, 13, 14, 16, 19, 20,28, pl. 5 trapezoides, Thracia _..._- 6, 14, 15, 18, 19,34, pl. 9 trochiformis, Trochita _..._..... 21 Trochita -_._. 19, 20 filosa inornata - sookensis _._. _ 


\begin{tabular}{|c|c|}
\hline Page & Page \\
\hline Trochita-Continued & U.S.G.S. fossil localities \\
\hline spirata & \\
\hline trochiformis & $\mathrm{V}$ \\
\hline n. $\mathbf{s p}$ & \\
\hline Trophonopsis & Vancouver Island \\
\hline sp & British Columbia, Canada \\
\hline Trophosycon clallamensis $\ldots \ldots 5,14,15,23$, pls. 1,2 & Vaqueros Formation 31 \\
\hline kernianum & Vaqueros Stage \\
\hline Turner, D. L., cited & California \\
\hline Turridae & Venericardia subtenta quadrata \\
\hline Turritella & Veneridae \\
\hline oregonensis _. & ventricosa, Archarax \\
\hline yaquinana & Venus clallamensis \\
\hline Turritellidae & olympidea \\
\hline Twin River & (Chione) angustifrons \\
\hline $\begin{array}{r}1,3,6,7,9,16 \text {, } \\
28,30,32,33,34\end{array}$ & $\begin{array}{l}\text { clallamensis } \\
\text { olympidea }\end{array}$ \\
\hline benthonic foraminiferal assemblages & $\begin{array}{r}4,5,10,13,14 \\
15,16,17,27,29, \text { pl. } 4\end{array}$ \\
\hline contact & sp \\
\hline depositional environment & victorianus, Polinices \\
\hline faunal hiatus._. 16 & vokesi, Natica _......... \\
\hline molluscan assemblages & Volutidae \\
\hline mollusks & \\
\hline twinensis, Macoma $-6,10,11,13,14,16,32$, pls. 6,7 & W \\
\hline $\mathrm{U}$ & Washington \\
\hline Ungulinidae & $\begin{array}{l}\text { depositional cycle } \\
\text { molluscan province }\end{array}$ \\
\hline
\end{tabular}

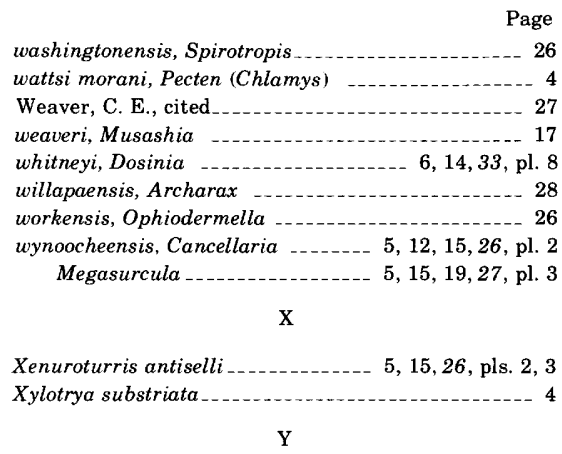

Yakataga Formation, Gulf of Alaska 31,34 yakatagense, Clinocardium yakatagensis, Cyclocardia _._._._... 30 yaquinana, Bruclarkia _........ $5,14,15,23$, pl. 2 Turritella

Yoldia impressa
reagani $-\ldots \ldots$
supramontereyensis tenuissima $\mathrm{Z}$

Zemorrian Stage 


\section{PLATES 1-9}

Contact photographs of the plates in this report are available, at cost, from U.S. Geological Survey Library, Federal Center, Denver, Colorado 80225. 


\section{PLATE 1}

Figures 1, 22. Crepidula praerupta Conrad.

1. Length $43 \mathrm{~mm}$, width $24 \mathrm{~mm}$. USNM 215926. USGS loc. M5886.

22. Length $22 \mathrm{~mm}$, width $18 \mathrm{~mm}$. USNM 215927 . USGS loc. M4050.

2, 3. Semicassis pyshtensis, $\mathrm{n}$. sp.

Holotype. Height $42 \mathrm{~mm}$, width $28 \mathrm{~mm}$. USNM 215928. USGS loc. M4414.

4, 5, 20, 24. Neverita jamesae Moore.

4, 5. Height $20 \mathrm{~mm}$, width $24 \mathrm{~mm}$. SUPTC 10182. SU loc. NP161.

20, 24. Height $11 \mathrm{~mm}$, width $15 \mathrm{~mm}$. USNM 215929. USGS loc. M4684.

6, 7. Crepidula princeps Conrad.

6. Length $42 \mathrm{~mm}$, width $26 \mathrm{~mm}$. USNM 215930. USGS loc. M5886.

7. Length $37 \mathrm{~mm}$, width $19 \mathrm{~mm}$. USNM 215931. USGS loc. M4414.

8, 13. Epitonium clallamense Durham.

8. Height $24 \mathrm{~mm}$, width $14 \mathrm{~mm}$. USNM 215932. USGS loc. M4413.

13. Height $28 \mathrm{~mm}$, width $18 \mathrm{~mm}$. USNM 215933. USGS loc. M4413.

9, 12, 18. Trochita n. sp. Moore.

9. Height $11 \mathrm{~mm}$, width $31 \mathrm{~mm}$. USNM 215934. USGS loc. M4678.

12. Height $14 \mathrm{~mm}$, width $32 \mathrm{~mm}$. USNM 215935 . USGS loc. M4681.

18. Height $9 \mathrm{~mm}$, width $20 \mathrm{~mm}$. USNM 215936 . USGS loc. M4049.

10, 11, 17. Turritella oregonensis (Conrad).

10. Height $18 \mathrm{~mm}$, width $4 \mathrm{~mm}$. USNM 215937. USGS loc. M4049.

11. Height $18 \mathrm{~mm}$, width $8 \mathrm{~mm}$. USNM 215938. USGS loc. M4049.

17. Height $14 \mathrm{~mm}$, width $8 \mathrm{~mm}$. USNM 215939 . USGS loc. M4049.

14-16. Natica vokesi Addicott.

14, 15. Height $17 \mathrm{~mm}$, width $19 \mathrm{~mm}$. USNM 215940. USGS loc. M4680.

16. Height $13 \mathrm{~mm}$, width $14 \mathrm{~mm}$. USNM 215941. USGS loc. M4680.

19, 27, 28. Natica cf. $N$. clarki Etherington.

19. Height $15 \mathrm{~mm}$, width $18 \mathrm{~mm}$. USNM 215942 . USGS loc. M5886.

27. Height $7 \mathrm{~mm}$, width $9 \mathrm{~mm}$. USNM 215943 . USGS loc. M4681.

28. Height $12 \mathrm{~mm}$, width $13 \mathrm{~mm}$. USNM 215944 . USGS loc. M5886.

21, 26. Sinum scopulosum (Conrad).

Height $13 \mathrm{~mm}$, width $19 \mathrm{~mm}$. USNM 215945. USGS loc. M4678.

23. Crepidula sp.

Height $10.5 \mathrm{~mm}$, width $16 \mathrm{~mm}$. USNM 215946. USGS loc. M4683.

25. Polinices victorianus Clark and Arnold.

Height $16 \mathrm{~mm}$, width $17 \mathrm{~mm}$. USNM 215947. USGS loc. M4681.

29, 30. Ficus modesta (Conrad).

Height $53 \mathrm{~mm}$, width $40 \mathrm{~mm}$. USNM 215948. USGS loc. M4678.

31. Trophosycon clallamensis (Weaver).

Height $78 \mathrm{~mm}$, width $55 \mathrm{~mm}$. SUPTC 10183. SU loc. NP89. 

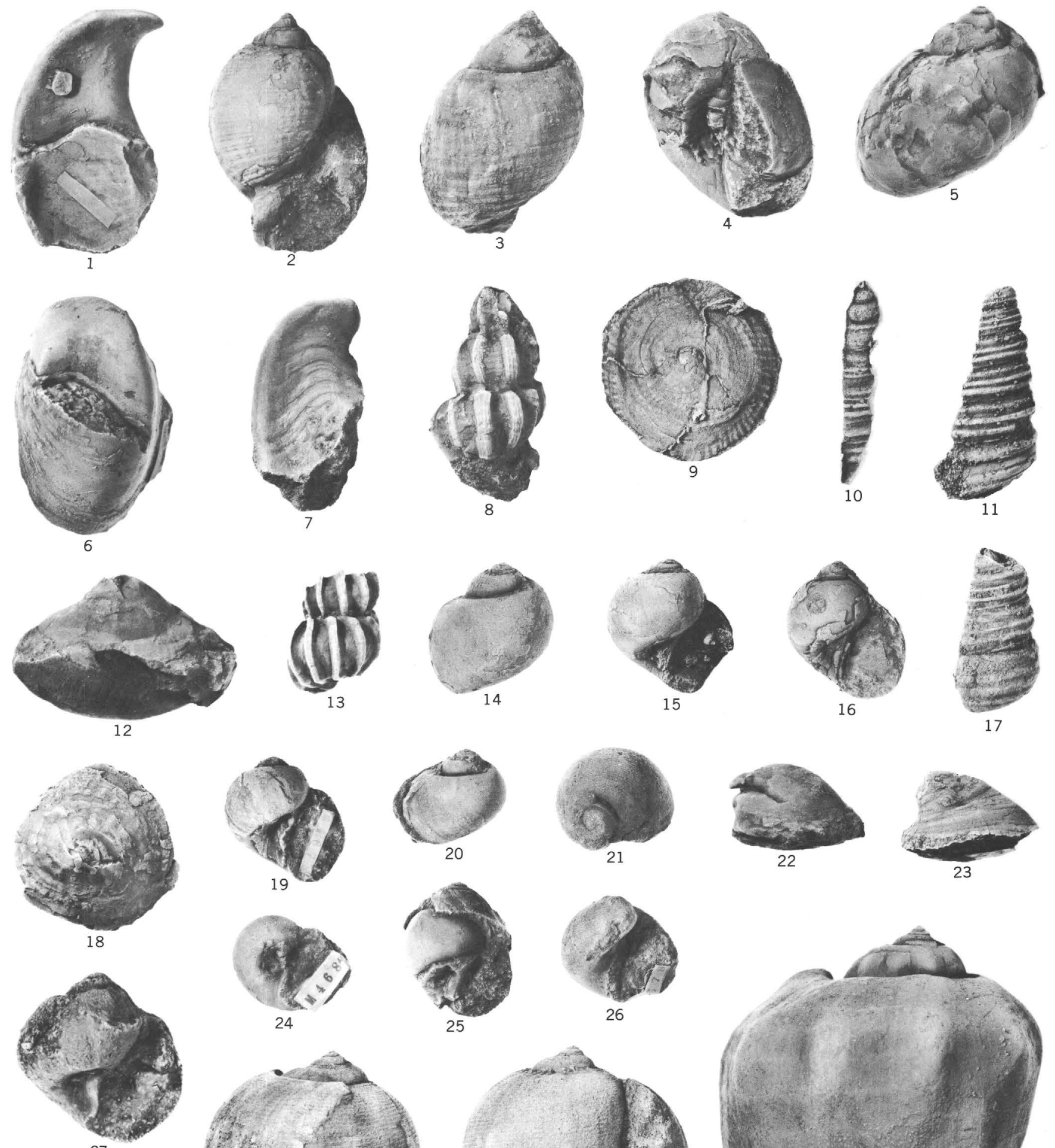

27

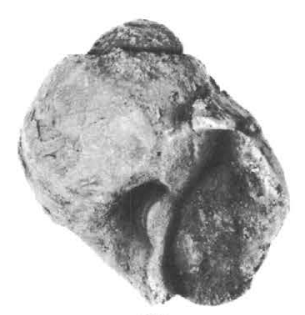

28
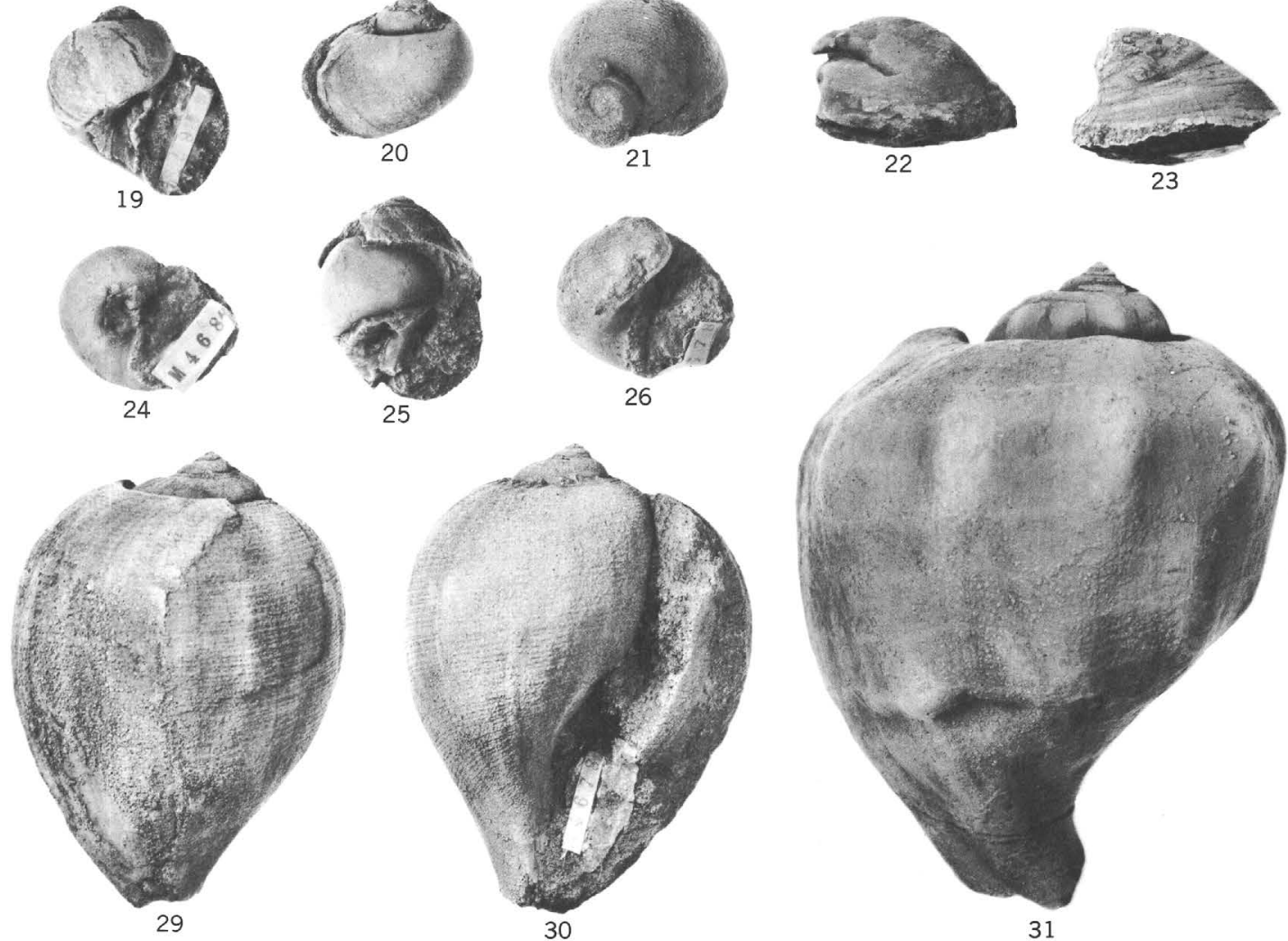

29

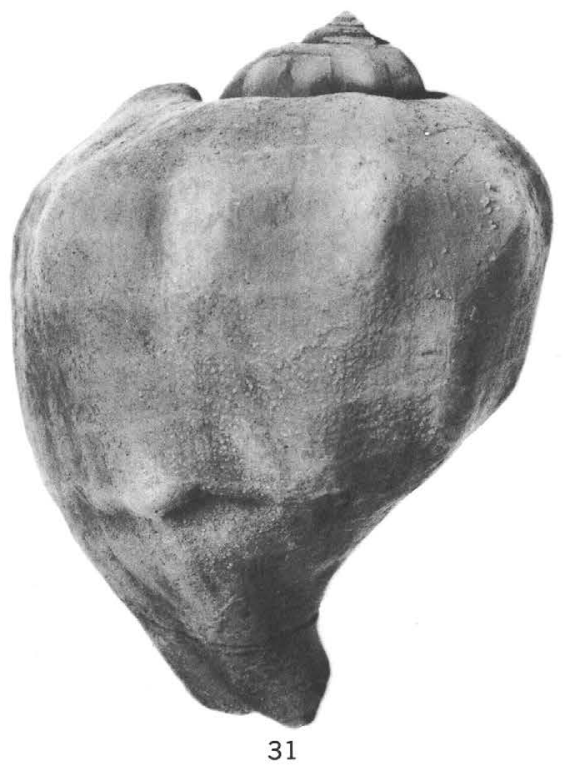

CREPIDULA, SEMICASSIS, NEVERITA, EPITONIUM, TROCHITA, TURRITELLA, NATICA, SINUM, POLINICES, FICUS, TROPHOSYCON 
PLATE 2

[Specimens are from the Clallam Formation unless otherwise specified]

Figures 1-3. Bruclarkia oregonensis (Conrad).

1. Height $40 \mathrm{~mm}$, width $30 \mathrm{~mm}$. USNM 215949. USGS loc. M4678.

2, 3. Height $43 \mathrm{~mm}$, width $28 \mathrm{~mm}$. USNM 215950. USGS loc. M4678.

4, 6, 19. Bruclarkia cf. B. oregonensis (Conrad).

4. Height $29 \mathrm{~mm}$, width $19 \mathrm{~mm}$. USNM 215951. USGS loc. M 4051.

6. Height $24 \mathrm{~mm}$, width $15 \mathrm{~mm}$. USNM 215952. USGS loc. M4051.

19. Height $23 \mathrm{~mm}$, width $13 \mathrm{~mm}$. USNM 215953. USGS loc. M4050.

5, 7-9. Bruclarkia yaquinana (Anderson and Martin).

5. Height $34 \mathrm{~mm}$, width $30 \mathrm{~mm}$. SUPTC 10184. SU loc. NP89.

7. Height $25 \mathrm{~mm}$, width $17 \mathrm{~mm}$. USNM 215954. USGS loc. M4050.

8. Height $22 \mathrm{~mm}$, width $15 \mathrm{~mm}$. USNM 215955. USGS loc. M4050.

9. Height $17 \mathrm{~mm}$, width $17 \mathrm{~mm}$. USNM 215956. USGS loc. M4051.

10, 11. Molopophorus newcombei (Merriam).

10. Height $29 \mathrm{~mm}$, width $16 \mathrm{~mm}$. USNM 215957. USGS loc. M4060, Sooke Formation, lower Miocene, southwest coast of Vancouver Island, British Columbia.

11. Height $34 \mathrm{~mm}$, width $18 \mathrm{~mm}$. USNM 215958. USGS loc. M4060, Sooke Formation, lower Miocene, southwest coast of Vancouver Island, British Columbia.

12. Priscofusus aff. $P$. geniculus (Conrad).

Height $28 \mathrm{~mm}$, width $16 \mathrm{~mm}$. USNM 215959. USGS loc. M4049.

13. Priscofusus slipensis, n. sp.

Holotype. Height $27 \mathrm{~mm}$, width $16 \mathrm{~mm}$. UW 13337. UW loc. 490.

14, 17, 18, 21. Priscofusus goweri, n. sp.

14. Paratype. Height $16 \mathrm{~mm}$, width $8 \mathrm{~mm}$. USNM 215960. USGS loc. M4049.

17. Paratype. Height $18 \mathrm{~mm}$, width $8 \mathrm{~mm}$. USNM 215961. USGS loc. M4049.

18. Holotype. Height $18 \mathrm{~mm}$, width $8 \mathrm{~mm}$. USNM 215962. USGS loc. M4049.

21. Paratype. Height $23 \mathrm{~mm}$, width $12 \mathrm{~mm}$. USNM 215963. USGS loc. M4049.

15. Priscofusus cf. P. stewarti (Tegland).

Height 19 mm, width 13 mm. USNM 215964. USGS loc. M4049.

16. Molopophorus n. sp. aff. M. newcombei (Merriam).

Height $26.5 \mathrm{~mm}$, width $18 \mathrm{~mm}$. USNM 215965. USGS loc. M5879.

20. Trophonopsis sp.

Height $10 \mathrm{~mm}$, width $6 \mathrm{~mm}$. USNM 215966. USGS loc. M4677.

22. Xenuroturris antiselli (Anderson and Martin).

Height $11 \mathrm{~mm}$, width $6 \mathrm{~mm}$. USNM 215998. USGS loc. M4683.

23, 25. Crepidula rostralis (Conrad).

Length $27 \mathrm{~mm}$, width $19 \mathrm{~mm}$, height $13.5 \mathrm{~mm}$. USNM 215967. USGS loc. M4051.

24. Crepidula praerupta Conrad.

Length $22 \mathrm{~mm}$, width $18 \mathrm{~mm}$, height $15 \mathrm{~mm}$. USNM 215967. USGS loc. M4050.

26-28. Cancellaria cf. C. oregonensis Conrad.

26. Height $14 \mathrm{~mm}$, width $7 \mathrm{~mm}$. USNM 215969. USGS loc. M4675.

27, 28. Height $13 \mathrm{~mm}$, width $7 \mathrm{~mm}$. USNM 215970 . USGS loc. M4049.

29. Cancellaria cf. C. siletzensis Hanna.

Height 19 mm, width 11.5 mm. USNM 215971. USGS loc. M4049.

30, 31. Cancellaria cf. C. simplex Anderson.

30. Height $23 \mathrm{~mm}$, width $17 \mathrm{~mm}$. USNM 215972. USGS loc. M4049.

31. Height $24 \mathrm{~mm}$, width $17 \mathrm{~mm}$. USNM 215973. USGS loc. M4049.

32, 35, 38. Cancellaria wynoocheensis Weaver.

32. Height $16 \mathrm{~mm}$, width $16 \mathrm{~mm}$. USNM 215974. USGS loc. M4049.

35. Height $19.5 \mathrm{~mm}$, width $13.5 \mathrm{~mm}$. USNM 215975. USGS loc. M4049.

38. Height $23 \mathrm{~mm}$, width $14.5 \mathrm{~mm}$. USNM 215976. USGS loc. M6375.

33. ?Rectiplanes sp.

Height $17.5 \mathrm{~mm}$, width $8 \mathrm{~mm}$. USNM 215977. USGS loc. M4049.

34. Trophosycon clallamensis (Weaver).

Height $22 \mathrm{~mm}$, width $21 \mathrm{~mm}$. USNM 215978. USGS loc. M4051.

36, 37. Cancellaria birchi Addicott.

Height $12 \mathrm{~mm}$, width $6 \mathrm{~mm}$. USNM 215979. USGS loc. M5879. 

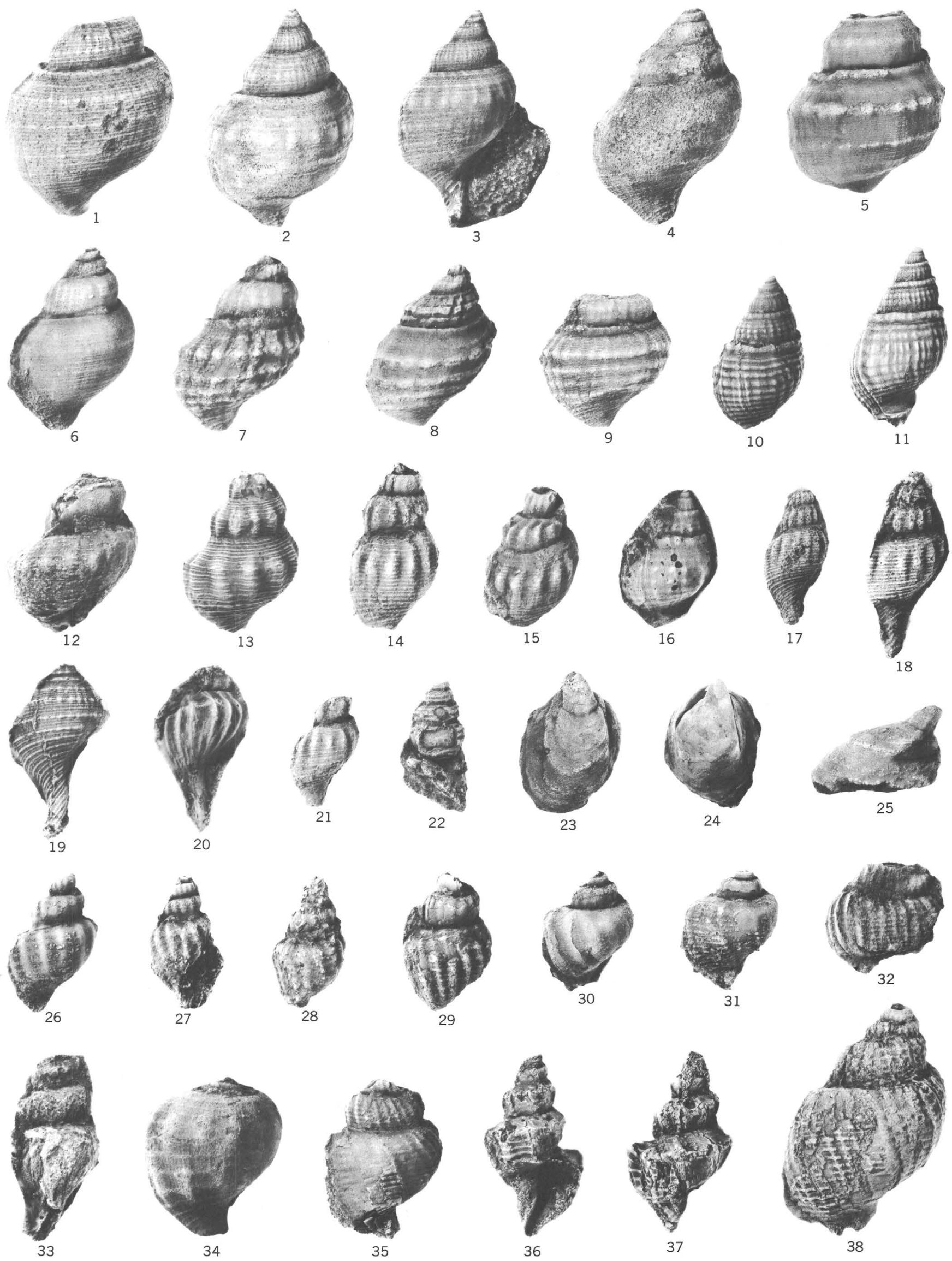

BRUCLARKIA, MOLOPOPHORUS, PRISCOFUSUS, TROPHONOPSIS, CREPIDULA,

CANCELLARIA, RECTIPLANES, TROPHOSYCON 
PLATE 3

[Specimens are from the Clallam Formation unless otherwise specified]

Figures 1-3. Acila conradi (Meek).

1. Length $19 \mathrm{~mm}$, height $16 \mathrm{~mm}$. SUPTC 10185. SU loc. NP163.

2. Length $21.5 \mathrm{~mm}$, height $19 \mathrm{~mm}$. USNM 215980. USGS loc. M4681.

3. Length $22 \mathrm{~mm}$, height $19 \mathrm{~mm}$. USNM 215981 . USGS loc. M4681. 4, 6, 10, 12-14. Nuculana calkinsi (Moore).

4. Length $17 \mathrm{~mm}$, height $10 \mathrm{~mm}$. USNM 215982 . USGS loc. M4677.

6. Length $14 \mathrm{~mm}$, height $8.5 \mathrm{~mm}$. USNM 215983. USGS loc. M4677.

10. Length $30 \mathrm{~mm}$, height $18 \mathrm{~mm}$. USNM 215984 . USGS loc. M4049.

12, 13. Length $19.5 \mathrm{~mm}$, height $11 \mathrm{~mm}$. USNM 215985. USGS loc. M5878.

14. Length $16 \mathrm{~mm}$, height $10 \mathrm{~mm}$. USNM 215986 . USGS loc. M4049.

5. Archarax dalli (Clark).

Length $61 \mathrm{~mm}$, height $22 \mathrm{~mm}$. USNM 215987. USGS loc. M4050.

7, 15. Yoldia supramontereyensis Arnold.

7. Length $41 \mathrm{~mm}$, height $27 \mathrm{~mm}$. USNM 215988. USGS loc. M4680.

15. Length $24 \mathrm{~mm}$, height $13 \mathrm{~mm}$. USNM 215989. USGS loc. M4680.

8, 9. Nuculana cf. N. elmana Etherington.

Length $21 \mathrm{~mm}$, height $12 \mathrm{~mm}$. USNM 215991. USGS loc. M6375.

11. Nuculana chehalisensis (Weaver).

Length $14 \mathrm{~mm}$, height $8 \mathrm{~mm}$. USNM 215990. USGS loc. M4678.

16, 17. Megasurcula cf. $M$. wynoocheensis (Weaver).

Height $31 \mathrm{~mm}$, width $15 \mathrm{~mm}$. UW 13339. UW loc. 490 .

18-20, 22. Ophiodermella olympicensis, n. sp.

18. Holotype. Height $16 \mathrm{~mm}$, width $6.5 \mathrm{~mm}$. USNM 215992. USGS loc. M4051.

19. Paratype. Height $14.5 \mathrm{~mm}$, width $8 \mathrm{~mm}$. USNM 215993. USGS loc. M4051.

20. Paratype. Height $11.5 \mathrm{~mm}$, width $8 \mathrm{~mm}$. USNM 215994. USGS loc. M4051

22. Paratype. Height $17 \mathrm{~mm}$, width $8 \mathrm{~mm}$. USNM 215995. USGS loc. M4051.

24, 25. Ophiodermella cf. O. olympicensis Addicott, n. sp.

24. Height $20 \mathrm{~mm}$, width $8 \mathrm{~mm}$. USNM 215996. USGS loc. M2514, Astoria Formation, lower or middle Miocene, Grays River quadrangle, southwestern Washington.

25. Height $14 \mathrm{~mm}$, width $8 \mathrm{~mm}$. USNM 215997. USGS loc. M2514, Astoria Formation, lower or middle Miocene, Grays River quadrangle, southwestern Washington.

21, 23. Xenuroturris antiselli (Anderson and Martin).

21. Height $11 \mathrm{~mm}$, width $6 \mathrm{~mm}$. USNM 215998. USGS loc. M4683.

23. Height $13 \mathrm{~mm}$, width $6 \mathrm{~mm}$. USNM 215999. USGS loc. M4683.

26. Ancistrolepis rearensis (Clark).

Height $47 \mathrm{~mm}$, width $28 \mathrm{~mm}$. UW60271. UW loc. 490 .

27. Musashia indurata (Conrad).

Height $74 \mathrm{~mm}$, width $34 \mathrm{~mm}$. USNM 216000 . USGS loc. M4050. 

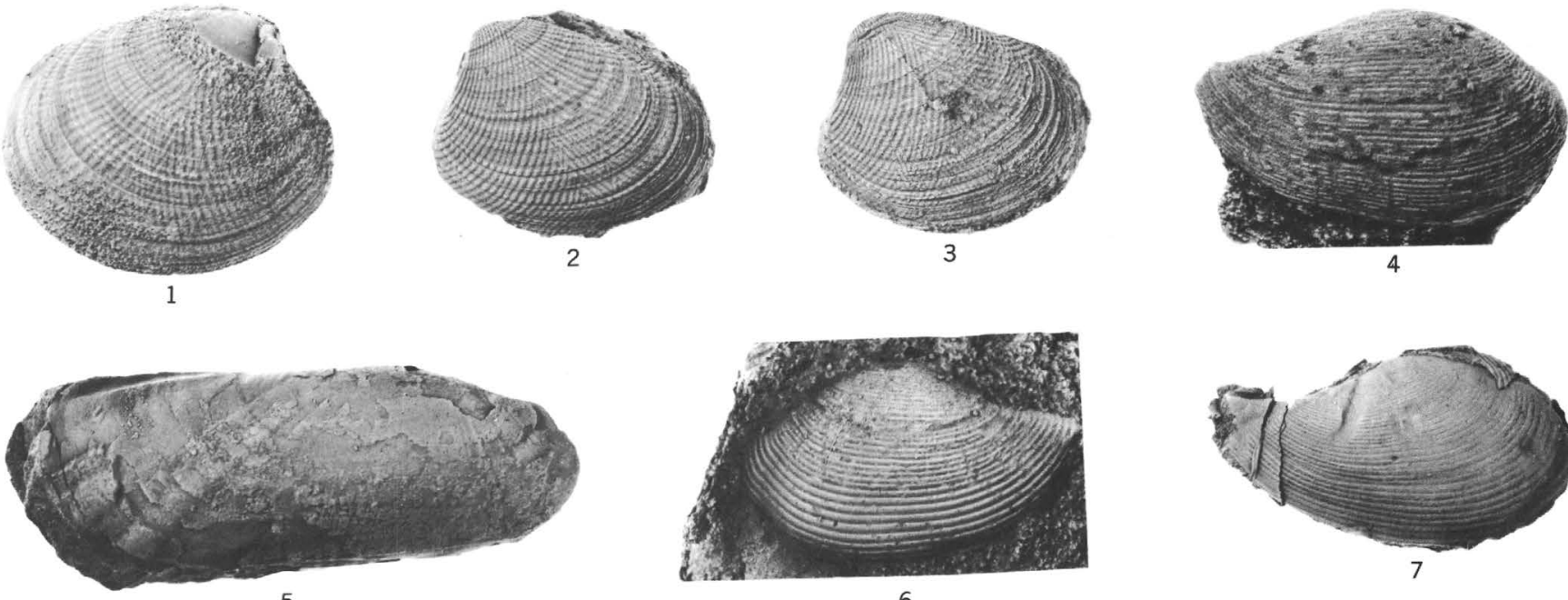

6
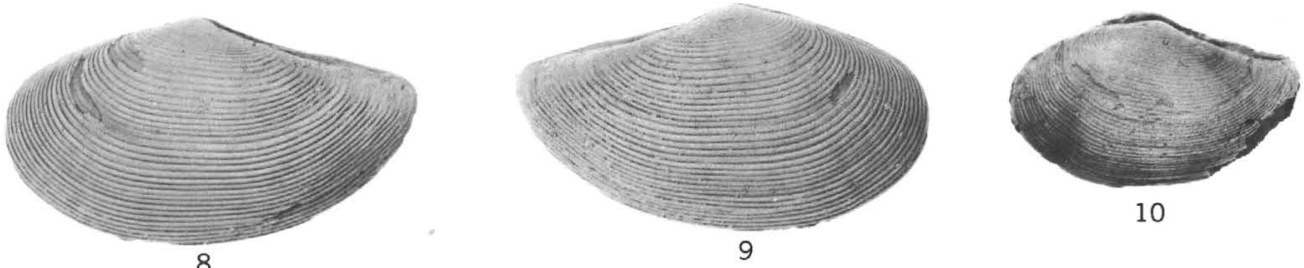

10
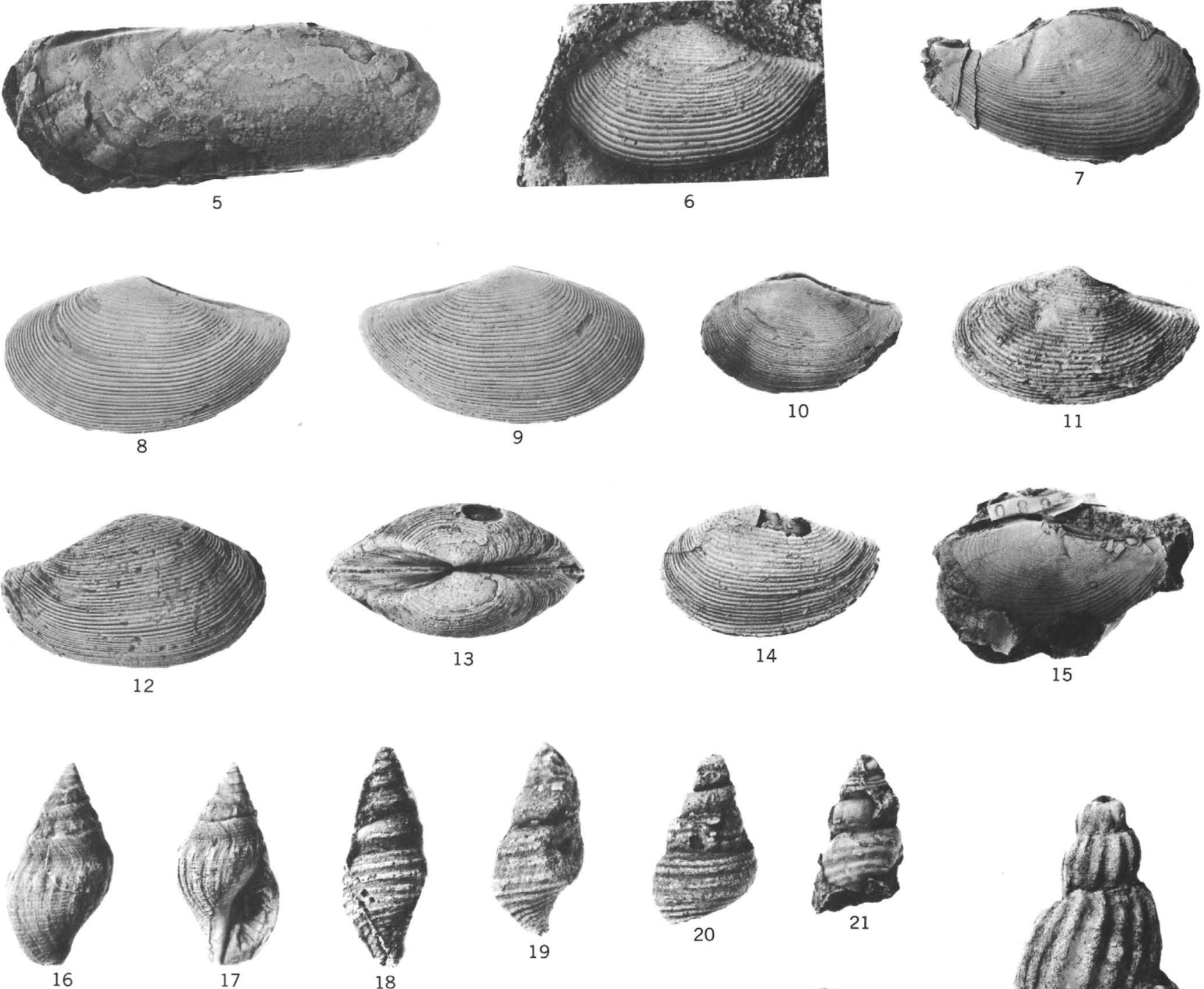

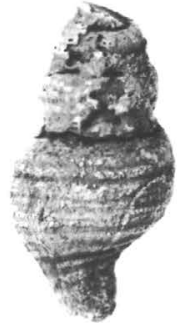

22

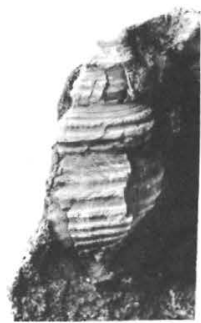

23
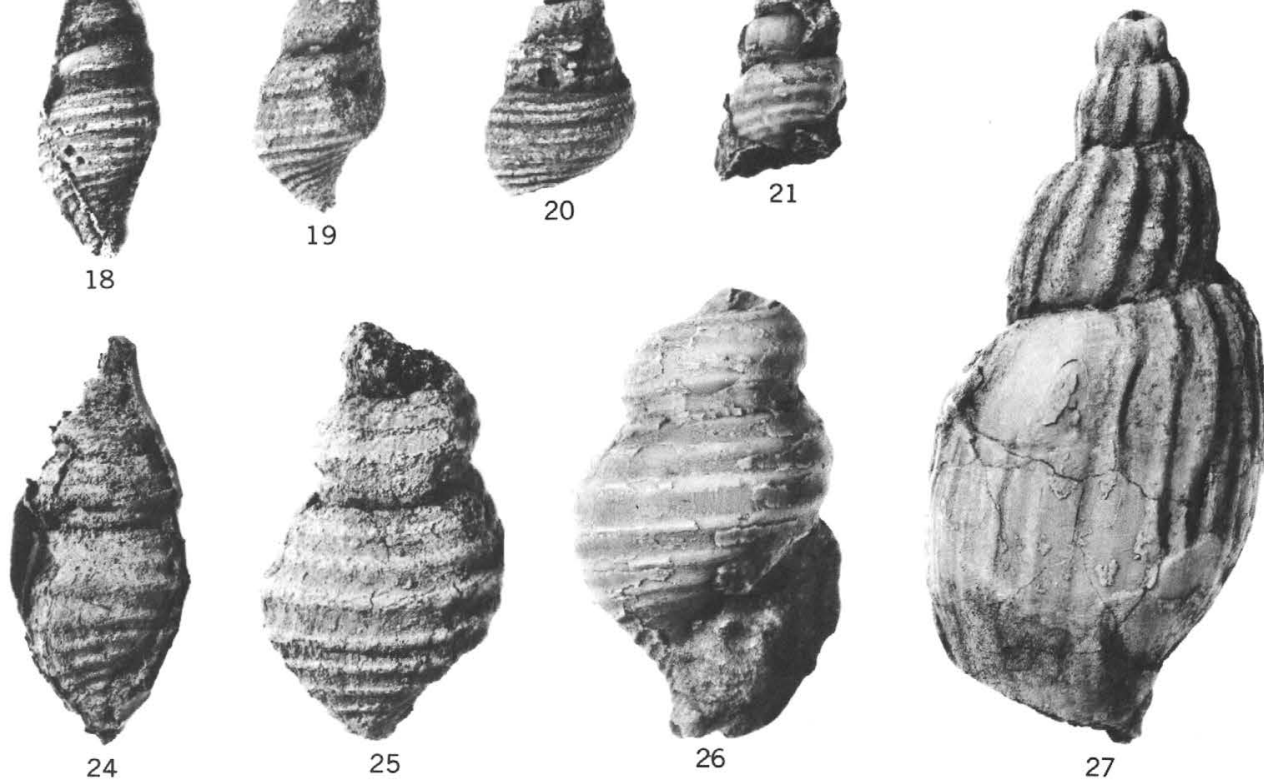

ACILA, NUCULANA, ARCHARAX, YOLDIA, MEGASURCULA, OPHIODERMELLA,

XENUROTURRIS, ANCISTROLEPIS, MUSASHIA 


\section{PLATE 4}

[Specimens are from the Clallam Formation unless otherwise specified]

Figures 1, 2, 5, 7, 10, 12. Vertipecten fucanus (Dall).

1. Length $64 \mathrm{~mm}$, height $68 \mathrm{~mm}$. USNM 216001. USGS loc. M4049.

2. Length $79 \mathrm{~mm}$, height $75 \mathrm{~mm}$. USNM 216002. USGS loc. M4414.

5. Length of fragment $56 \mathrm{~mm}$. USNM 216003. USGS loc. M4678.

7. Length $46 \mathrm{~mm}$, height $44 \mathrm{~mm}$. USNM 216009. USGS loc. M4049.

10. Length $51 \mathrm{~mm}$, height $60 \mathrm{~mm}$. USNM 215968. USGS loc. M4678.

12. Length $80 \mathrm{~mm}$, height $85 \mathrm{~mm}$. USNM 216004. USGS loc. M4049.

3, 11. Solamen porterensis (Weaver).

Length $10 \mathrm{~mm}$, height $12 \mathrm{~mm}$. USNM 216005. USGS loc. 18977, Lincoln Creek Formation, upper Oligocene, Grays Harbor basin, southwestern Washington.

4, 8. Dentalium pseudonyma Pilsbry and Sharp.

4. Length $28 \mathrm{~mm}$, width $6 \mathrm{~mm}$. SUPTC 10188. SU loc. NP89.

8. Length $19 \mathrm{~mm}$, width $4 \mathrm{~mm}$. USNM 216006. USGS loc. M4049. 6, 9. Solamen snavelyi, $\mathrm{n}$. sp.

6. Paratype. Length $14 \mathrm{~mm}$, height $19 \mathrm{~mm}$. USNM 216007. USGS loc. M4050.

9. Holotype. Length $14 \mathrm{~mm}$, height $21 \mathrm{~mm}$. USNM 216008. USGS loc. M4051. 
GEOLOGICAL SURVEY
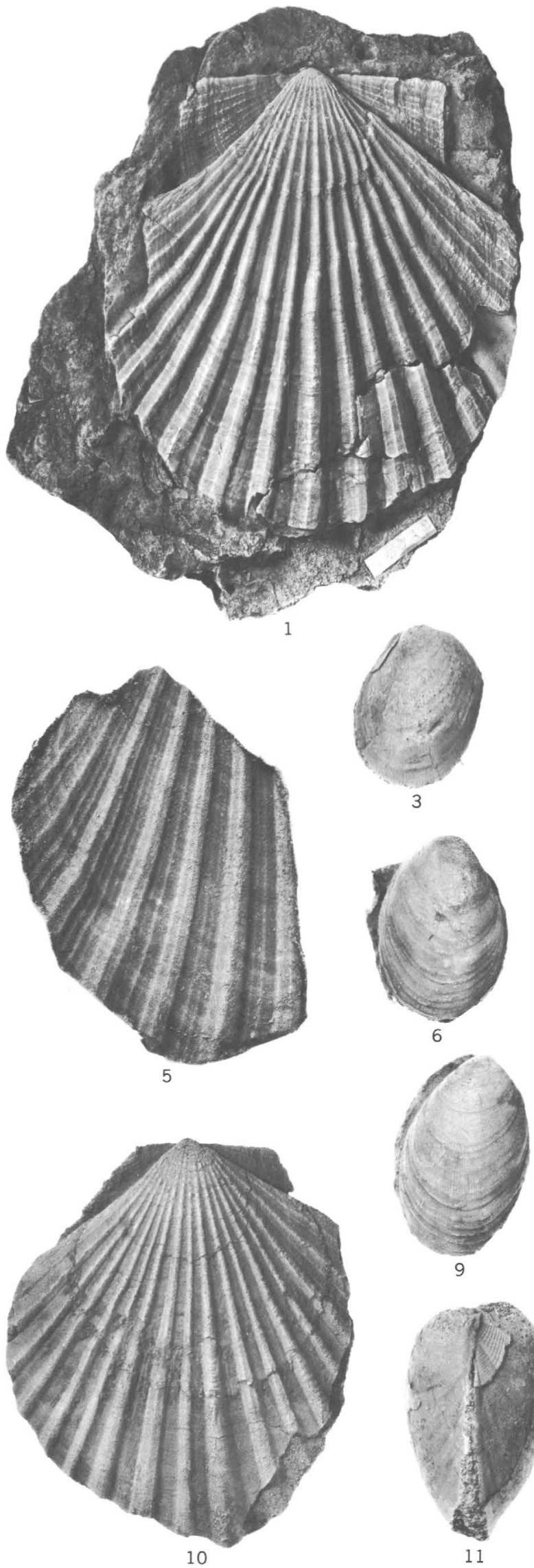

PROFESSIONAL PAPER 976 PLATE 4
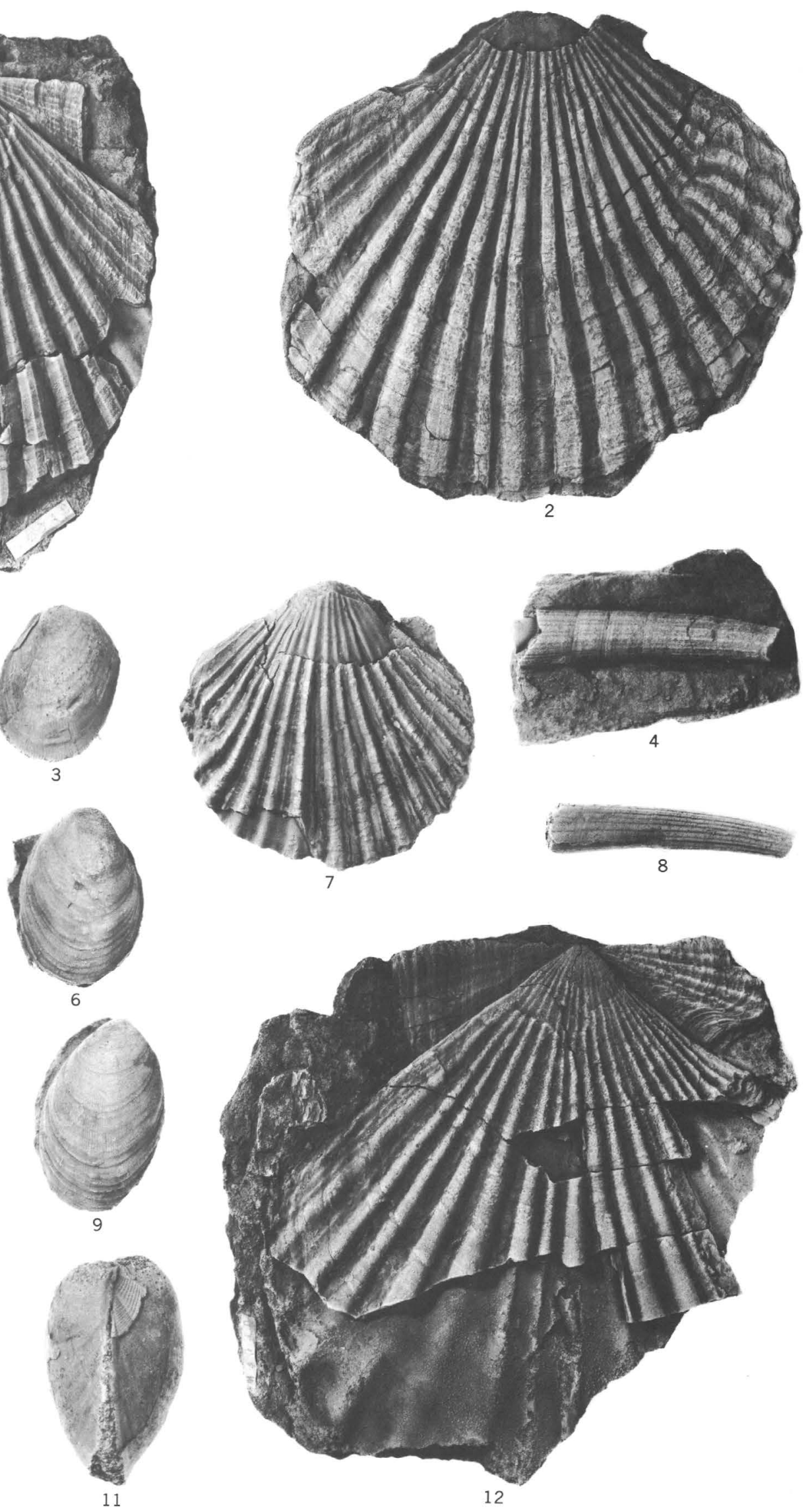


\section{PLATE 5}

[Specimens are from the Clallam Formation unless otherwise specified]

Figures 1, 2, 16, 18. Mytilus n. sp. aff. M. tichanovitchi Makiyama.

1. Length $42 \mathrm{~mm}$, height $82 \mathrm{~mm}$. SUPTC 10189. SU loc. NP89.

2. Length $36 \mathrm{~mm}$, height $84 \mathrm{~mm}$. SUPTC 10190. SU loc. NP89.

16, 18. Length 38, height $102 \mathrm{~mm}$. SUPTC 10191. SU loc. NP89.

3. Glycymeris sp.

Length $27 \mathrm{~mm}$, height $26 \mathrm{~mm}$. USNM 216010. USGS loc. M4684.

4, 7, 15. Lucinoma acutilineata (Conrad).

4. Length $26 \mathrm{~mm}$, height $23 \mathrm{~mm}$. USNM 216011. USGS loc. M4050.

7. Length $38 \mathrm{~mm}$, height $35 \mathrm{~mm}$. SUPTC 10192. SU loc. NP163.

15. Length $33 \mathrm{~mm}$, height $32 \mathrm{~mm}$. USNM 216012 . USGS loc. M4414.

5. Modiolus n. sp.? aff. $M$. restorationensis Van Winkle.

Length $29 \mathrm{~mm}$, height $56 \mathrm{~mm}$. USNM 216013. USGS loc. M4050.

6. Anadara cf. A. devincta (Conrad).

Length $40 \mathrm{~mm}$, height $29 \mathrm{~mm}$. USNM 216014. USGS loc. M4678.

8, 9. Anadara aff. A. lakei (Wiedey).

8. Length $40 \mathrm{~mm}$, height $32 \mathrm{~mm}$. USNM 216015. USGS loc. M4050.

9. Length $32 \mathrm{~mm}$, height $27 \mathrm{~mm}$. USNM 216016. USGS loc. M4050.

10. Anadara devincta (Conrad).

Length $44 \mathrm{~mm}$, height $32 \mathrm{~mm}$. USNM 216017. USGS loc. M4678.

11. Dentalium schencki Moore.

Length $38 \mathrm{~mm}$, width $8 \mathrm{~mm}$. USNM 216018. USGS loc. M4049.

12. Cyclocardia subtenta (Conrad).

Length $21 \mathrm{~mm}$, width $20 \mathrm{~mm}$. USNM 216019. USGS loc. M5878.

13. Clinocardium n. sp. aff. C. nuttalli (Conrad) Moore.

Length $38 \mathrm{~mm}$, width $36 \mathrm{~mm}$. USNM 216020. USGS loc. M4681.

14. Mytilus tichanovitchi Makiyama.

Length $135 \mathrm{~mm}$, height $79 \mathrm{~mm}$. USNM 216021. Ashai Formation, 17. Felaniella sp.

Miocene, central Hokkaido, Japan (Kanno and others, 1968).

Length $22 \mathrm{~mm}$, height $22 \mathrm{~mm}$. USNM 216022. USGS loc. M4413. 

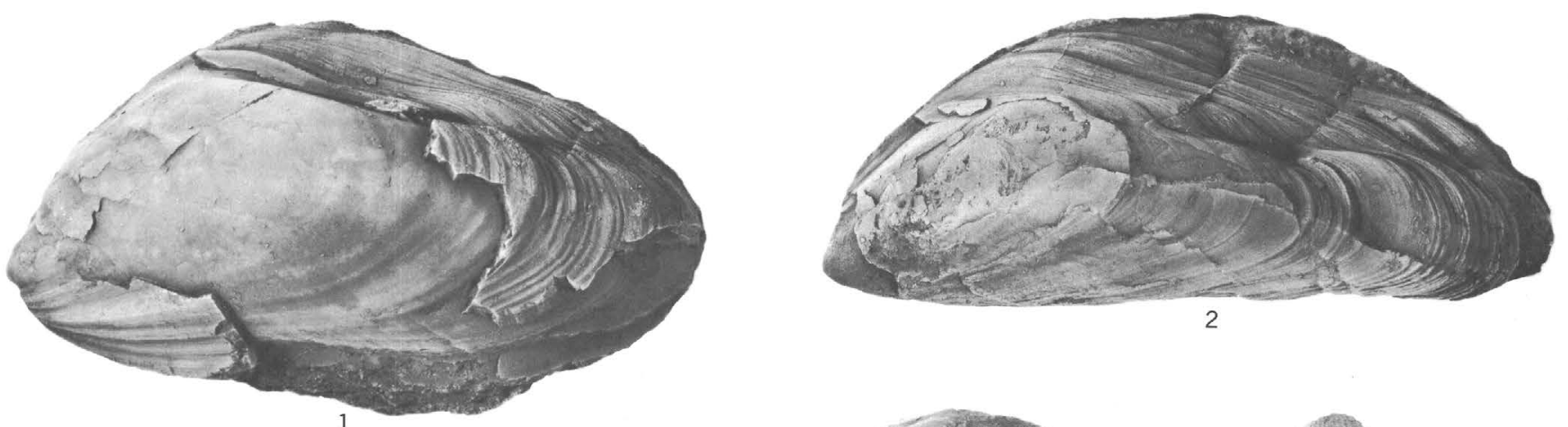

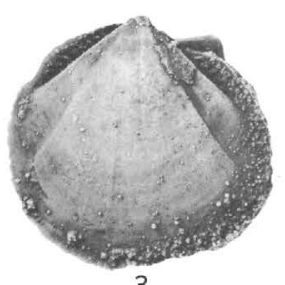

3
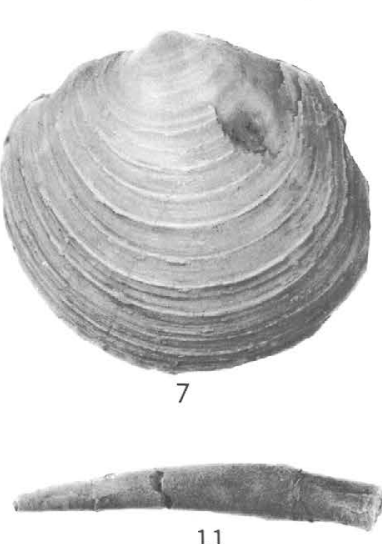

11

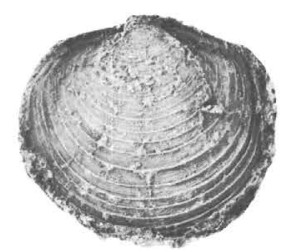

4
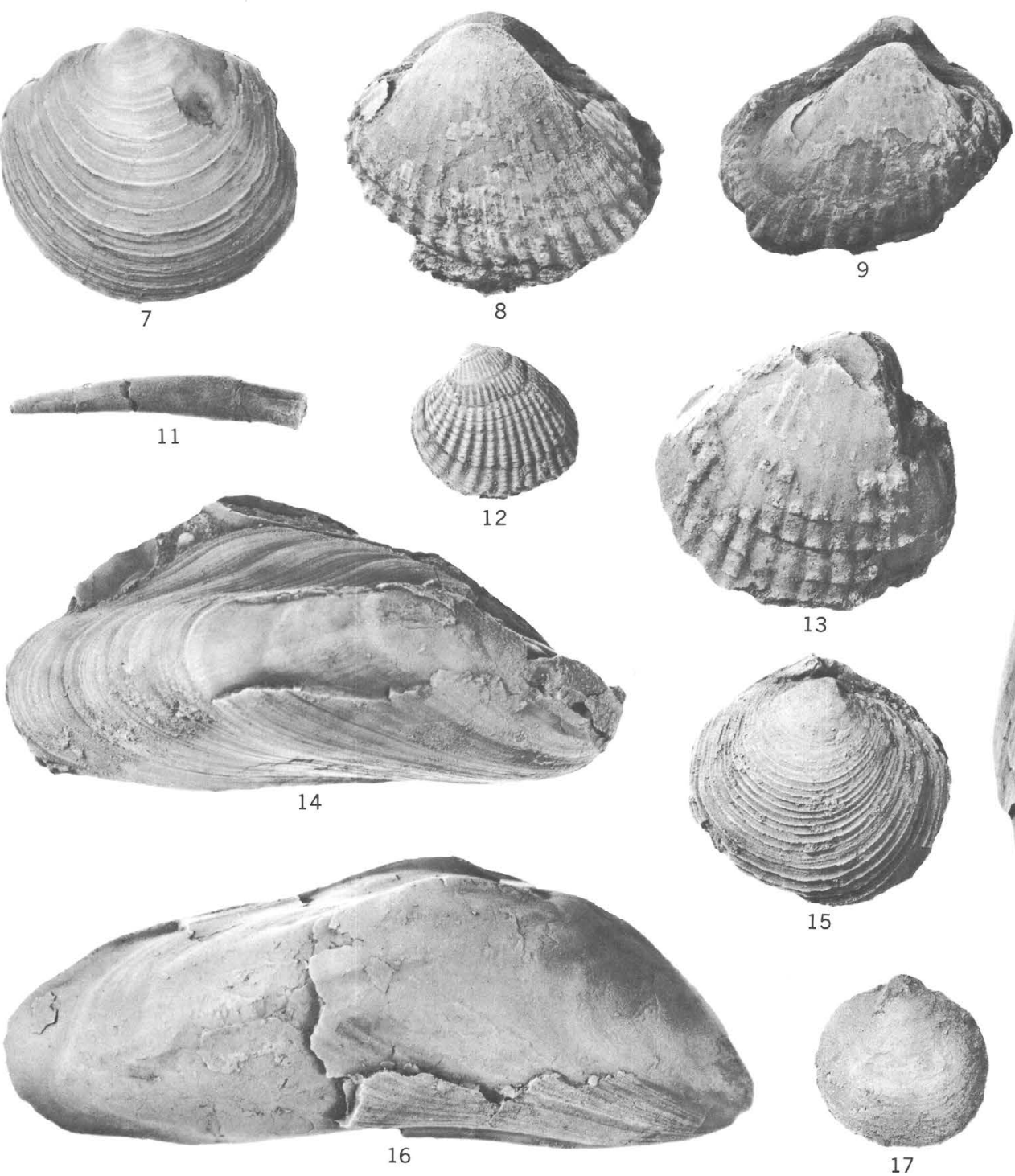
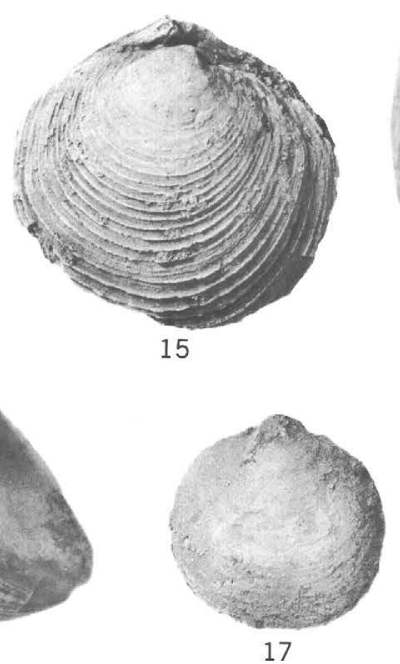
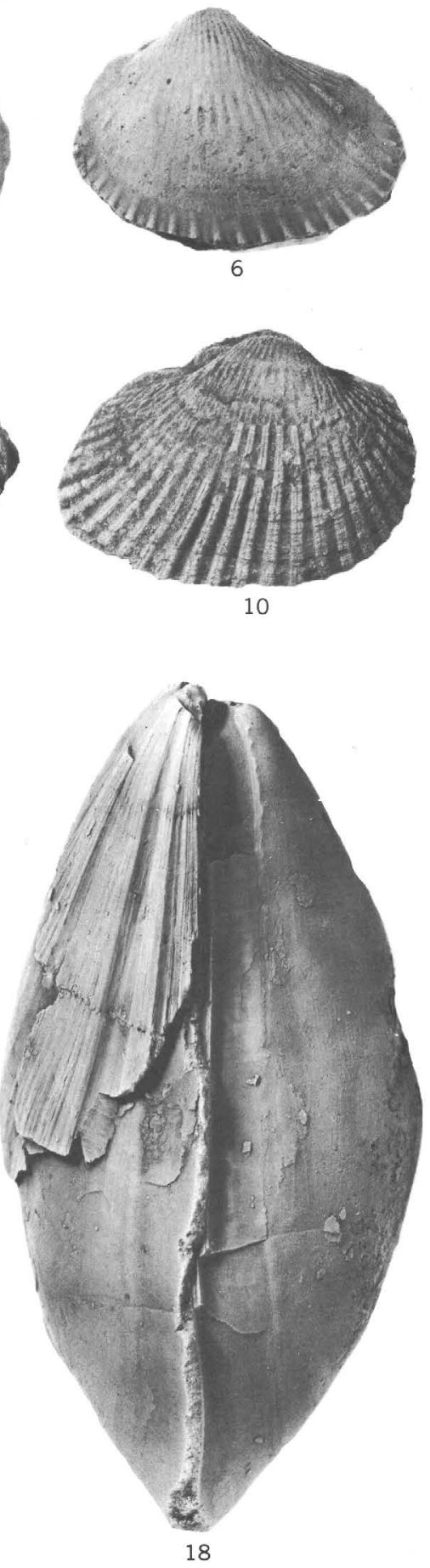

MYTILUS, GL YCYMERIS, LUCINOMA, MODIOLUS, ANADARA, DENTALIUM, CYCLOCARDIA, CLINOCARDIUM, FELANIELLA 


\section{PLATE 6}

[Specimens are from the Clallam Formation unless otherwise specified ]

Figures $\quad 1,16$. Spisula sookensis Clark and Arnold.

1. Length $64 \mathrm{~mm}$, height $57 \mathrm{~mm}$. USNM 216023. USGS loc. M4049.

16. Length 81, height $70 \mathrm{~mm}$. SUPTC 10193. SU loc. NP89.

2, 4, 13, 15. Macoma twinensis Clark.

2, 4. Length $31 \mathrm{~mm}$, height $22 \mathrm{~mm}$. USNM 216024 . USGS loc. M4032. Upper member of the Twin River Formation, lower Miocene, western Washington.

13, 15. Length $26 \mathrm{~mm}$, height $18 \mathrm{~mm}$. USNM 216025. USGS loc. M4032. Upper member of the Twin River Formation, lower Miocene, western Washington.

3. Spisula albaria (Conrad).

Length $54 \mathrm{~mm}$, height $46 \mathrm{~mm}$. USNM 216026. USGS loc. M4051.

5. Macoma cf. M. twinensis Clark.

Length $23 \mathrm{~mm}$, height $14 \mathrm{~mm}$. USNM 216027. USGS loc. M4677.

6. Spisula sp.

Length $65 \mathrm{~mm}$, height $48 \mathrm{~mm}$. USNM 216028. USGS loc. M4049.

7. Conchocele disjuncta Gabb.

Length $43 \mathrm{~mm}$, height $51 \mathrm{~mm}$. USNM 216029. USGS loc. M4050.

8. Clinocardium n. sp. aff. C. nuttalli (Conrad) Moore.

Length $43 \mathrm{~mm}$, height $43 \mathrm{~mm}$. USNM 216030. USGS loc. M4049.

9, 10. Cyclocardia subtenta (Conrad).

9. Length $20 \mathrm{~mm}$, height $20 \mathrm{~mm}$. USNM 216031. USGS loc. M4049.

10. Length $15 \mathrm{~mm}$, height $15 \mathrm{~mm}$. USNM 216032. USGS loc. M4677.

11. Spisula ef. S. hannibali Clark and Arnold.

Length $65 \mathrm{~mm}$, height $46 \mathrm{~mm}$. USNM 216033. USGS loc. M4675.

12. Solen conradi Dall.

Length $43 \mathrm{~mm}$, height $13 \mathrm{~mm}$. USNM 216034. USGS loc. M4050.

14. Spisula albaria goodspeedi Etherington.

Length $58 \mathrm{~mm}$, height $49 \mathrm{~mm}$. USNM 216035 . USGS loc. M4414. 

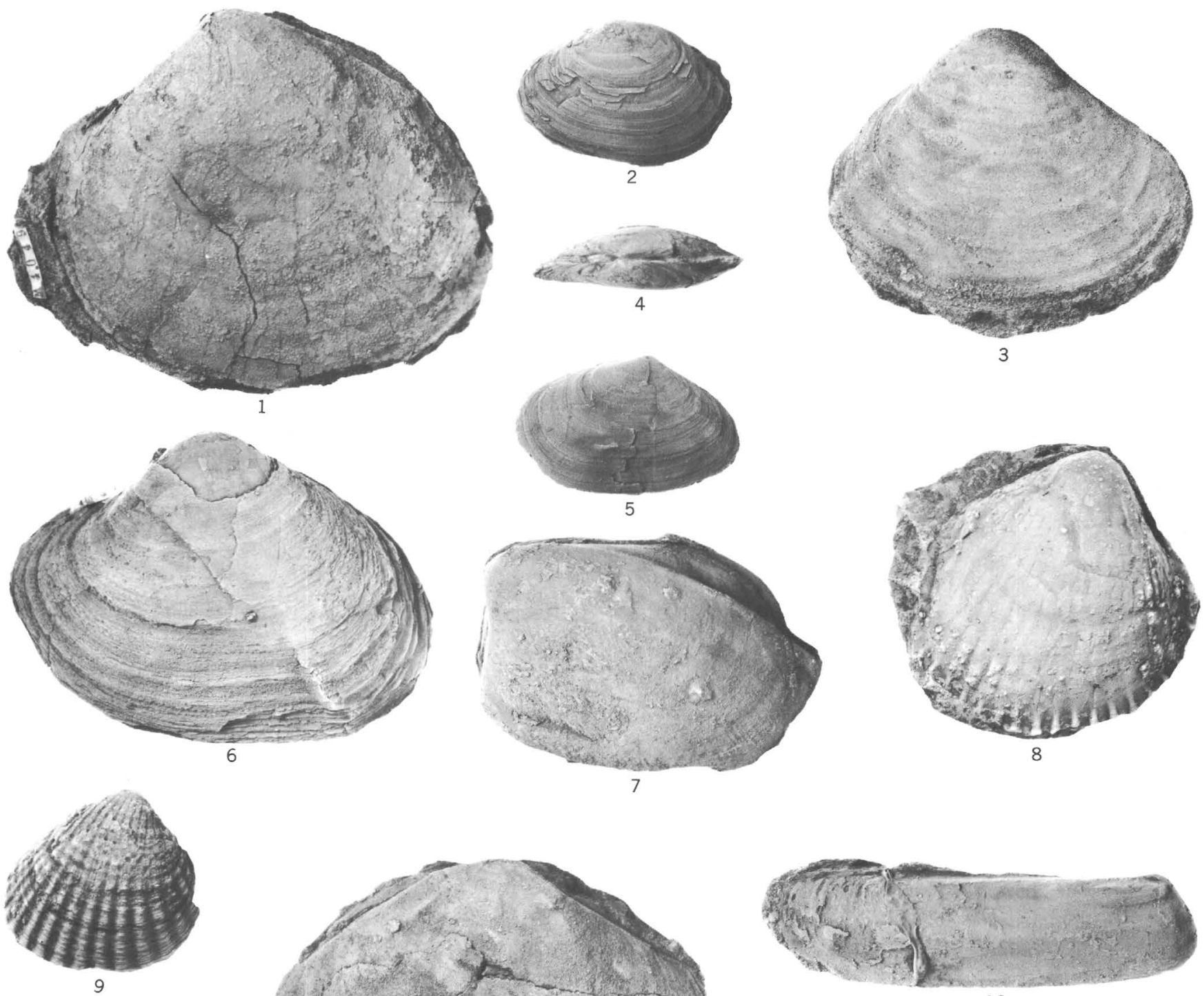

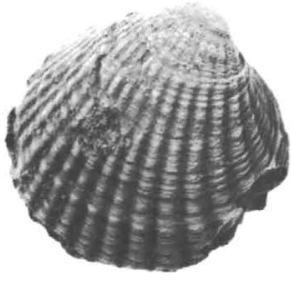

10

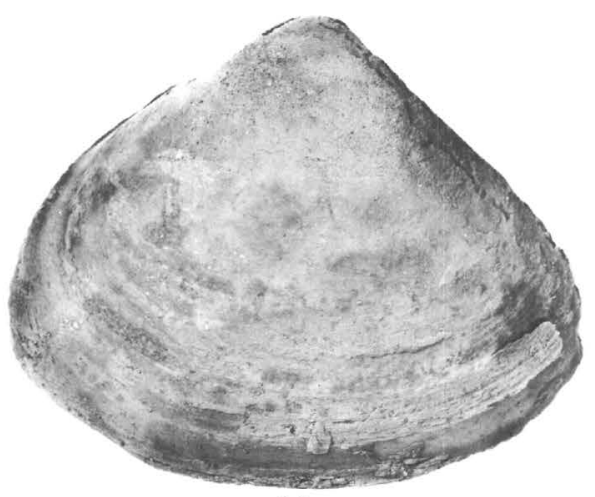

14
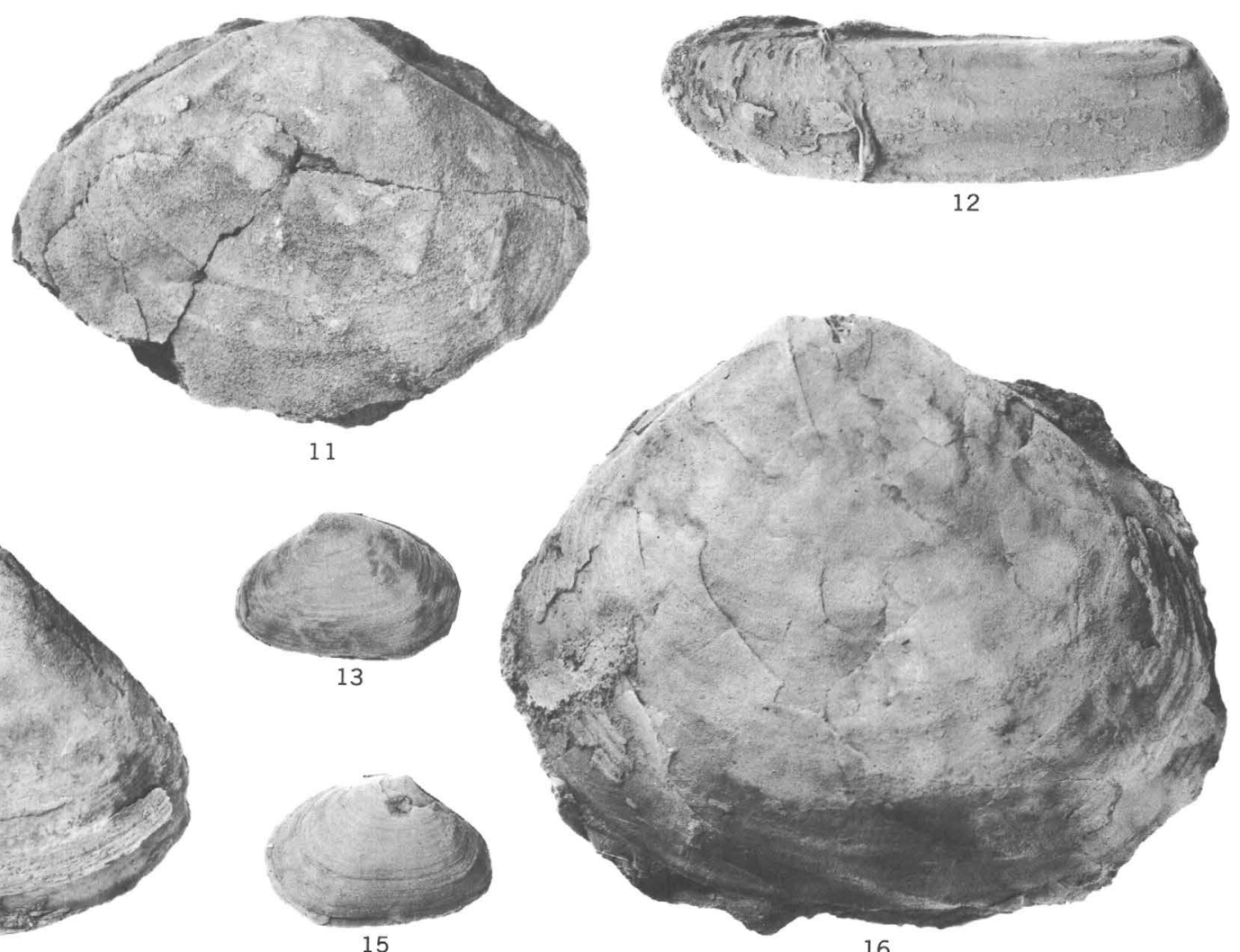

SPISULA, MACOMA, CONCHOCELE, CLINOCARDIUM, CYCLOCARDIA, SOLEN 


\section{PLATE 7}

[Specimens are from the Clallam Formation unless otherwise specified]

Figures

Length $49 \mathrm{~mm}$, height $40 \mathrm{~mm}$. USNM 216036. USGS loc. M4049.

2, 3, 11. Spisula albaria (Conrad).

2, 3. Mactra gibbsana Meek of Reagan (1909). Length $55 \mathrm{~mm}$, height $40 \mathrm{~mm}$. USNM 32832 . Probably from the east side of Clallam Bay near Slip Point.

11. Length $31 \mathrm{~mm}$, height $25 \mathrm{~mm}$. USNM 216037. USGS loc. M4051.

4, 6, 8, 14, 18, 22. Macoma arctata (Conrad).

4. Length $52 \mathrm{~mm}$, height $31 \mathrm{~mm}$. USNM 216038. USGS loc. M4051.

6. Length $41 \mathrm{~mm}$, height $25 \mathrm{~mm}$. USNM 216039. USGS loc. M4051.

8. Length $50 \mathrm{~mm}$, height $32 \mathrm{~mm}$. USNM 216040. USGS loc. M5886.

14. Holotype of Tellina arctata var. juana Reagan (1909). Length $55 \mathrm{~mm}$, height $33 \mathrm{~mm}$. USNM 328319. Near Slip Point.

18. Length $45 \mathrm{~mm}$, height $28 \mathrm{~mm}$. USNM 216041. USGS loc. M4049.

22. Length $61 \mathrm{~mm}$, height $35 \mathrm{~mm}$. USNM 216042. USGS loc. M4049.

5, 7, 10. Tellina emacerata Conrad.

5. Length $37 \mathrm{~mm}$, height $21 \mathrm{~mm}$. USNM 216043. USGS loc. M4684.

7. Length $32 \mathrm{~mm}$, height $18 \mathrm{~mm}$. USNM 216044. USGS loc. M4051.

10. Holotype of Tellina clallamensis Reagan (1909). Length 33 $\mathrm{mm}$, height $19 \mathrm{~mm}$. USNM 328320. Near Slip Point.

9. Macoma cf. M. astori Dall.

Length $38 \mathrm{~mm}$, height $28 \mathrm{~mm}$. USNM 216045. USGS loc. M4049.

12. Macoma twinensis Clark.

Length $34 \mathrm{~mm}$, height $23 \mathrm{~mm}$. USNM 216048. USGS loc. M4032. Upper member of the Twin River Formation, lower Miocene, western Washington.

13-15, 17, 20. Macoma albaria Conrad.

13, 17, 20. Length $22 \mathrm{~mm}$, height $15 \mathrm{~mm}$. USNM 216046. USGS loc. M4050.

14, 15. Length $17 \mathrm{~mm}$, height $12 \mathrm{~mm}$. USNM 216047. USGS loc. M4677.

16, 19. Macoma arnoldi Tegland.

Length $32 \mathrm{~mm}$, height $26 \mathrm{~mm}$. USNM 216049. USGS loc. M4042. Blakeley Formation, upper Oligocene, Restoration Point, Washington.

21. Macoma astori Dall.

Length $52 \mathrm{~mm}$, height $46 \mathrm{~mm}$. USNM 216050. USGS loc. M4049.

23. Macoma sookensis Clark and Arnold.

Length $54 \mathrm{~mm}$, height $41 \mathrm{~mm}$. SUPTC 10194. SU loc. NP161. 

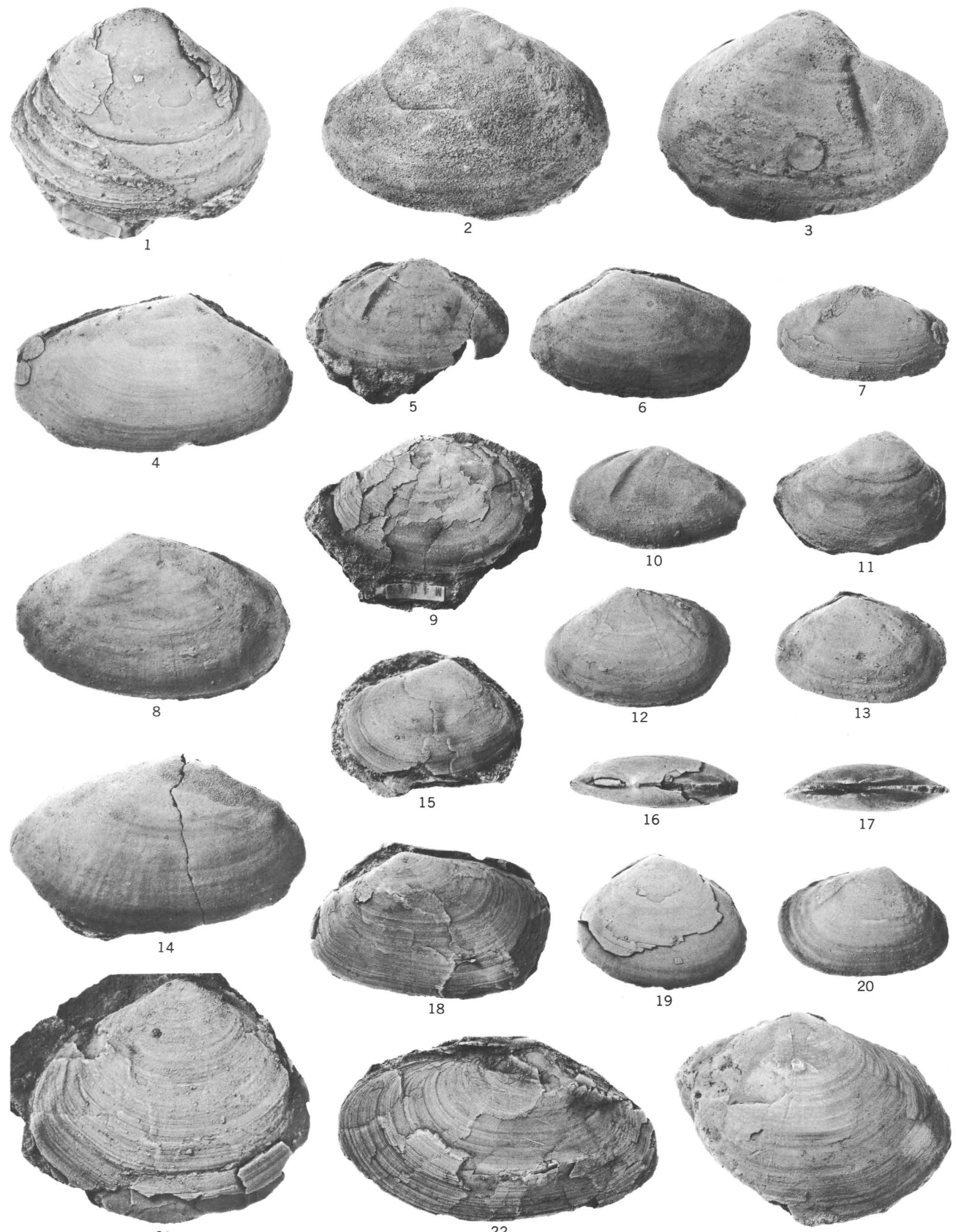

21
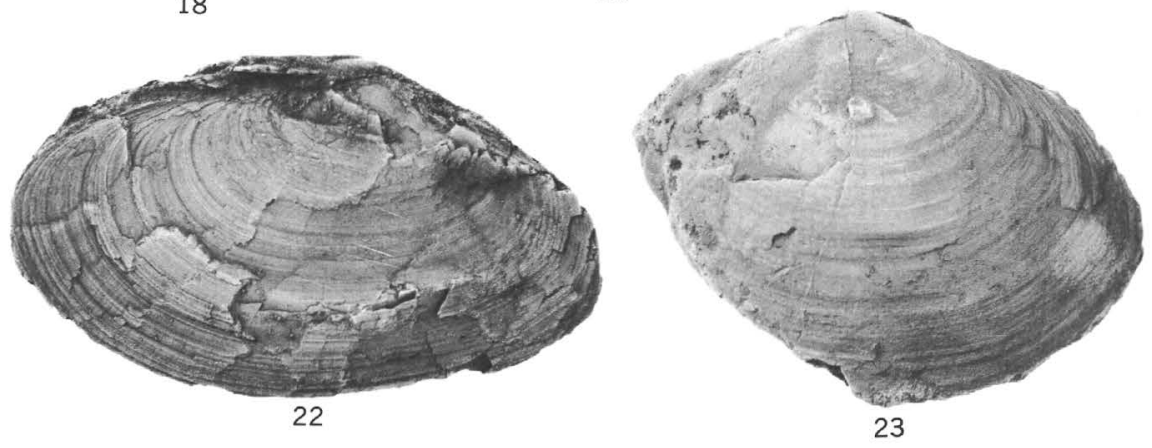

SPISULA, MACOMA, TELLINA 


\section{PLATE 8}

[Specimens are from the Clallam Formation unless otherwise specified]

Figures

1, 2, 5. Macoma sookensis Clark and Arnold.

1. Length $58 \mathrm{~mm}$, height $43 \mathrm{~mm}$. SUPTC 10195. SU loc. NP161.

2. Length $50 \mathrm{~mm}$, height $48 \mathrm{~mm}$. USNM 216051 . USGS loc. M4681.

5. Length $49 \mathrm{~mm}$, height $38 \mathrm{~mm}$. USNM 216052 . USGS loc. M4681.

3. Macoma flagleri Etherington.

Length $44 \mathrm{~mm}$, height $31 \mathrm{~mm}$. USNM 216053. USGS loc. M1495, Astoria Formation, lower or middle Miocene, Grays Harbor basin, southwestern Washington.

4. Macoma n. sp. Moore.

Length $46 \mathrm{~mm}$, height $42 \mathrm{~mm}$. USNM 216054. USGS loc. M4683.

6. Macoma n. sp. aff. M. secta (Conrad).

Length $41 \mathrm{~mm}$, height $30 \mathrm{~mm}$. USNM 216055 . USGS loc. M4678.

7, 8, 11-18. Katherinella angustifrons (Conrad).

7. Inflated form. Length $31 \mathrm{~mm}$, height $30 \mathrm{~mm}$. USNM 216056. USGS loc. M4677.

8, 11. Thin form. Length $37 \mathrm{~mm}$, height $35 \mathrm{~mm}$. USNM 216058. USGS loc. M4049.

12. Length $40 \mathrm{~mm}$, height $36 \mathrm{~mm}$. SUPTC 10196. SU loc. NP163.

13. Length $58 \mathrm{~mm}$, height $45 \mathrm{~mm}$. USNM 216057 . USGS loc. M4051.

14, 16. Thin form. Length $41 \mathrm{~mm}$, height $41 \mathrm{~mm}$. USNM 216059. USGS loc. M4050.

15, 17. Inflated form. Length $46 \mathrm{~mm}$, height $43 \mathrm{~mm}$. USNM 216060. USGS loc. M4050.

18. Thin form. Length $64 \mathrm{~mm}$, height $57 \mathrm{~mm}$. USNM 216061, USGS loc. M4049.

9, 10. Dosinia whitneyi (Gabb).

9. Length $25 \mathrm{~mm}$, height $22 \mathrm{~mm}$. USNM 216062. USGS loc. M4684.

10. Length $30 \mathrm{~mm}$, height $31 \mathrm{~mm}$. USNM 216063. USGS loc. M4683. 
GEOLOGICAL SURVEY
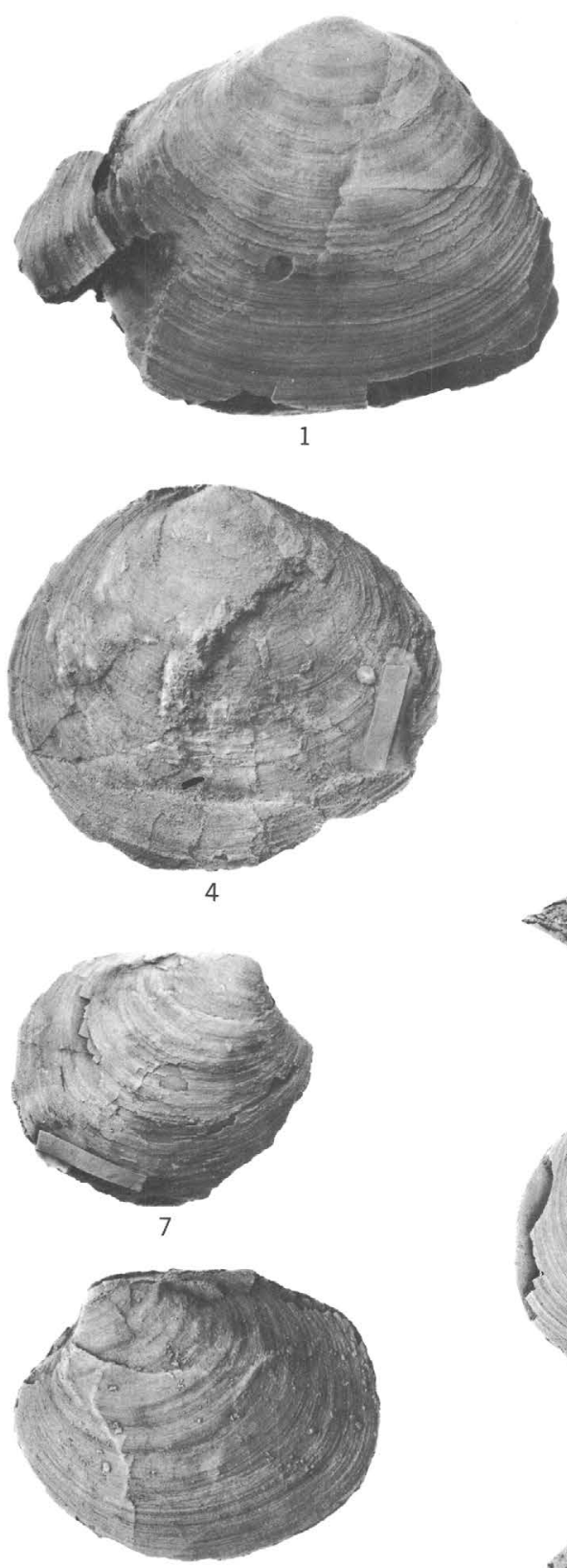

11

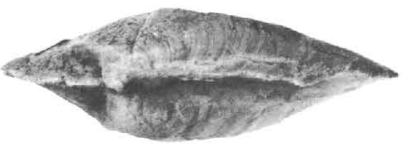

14

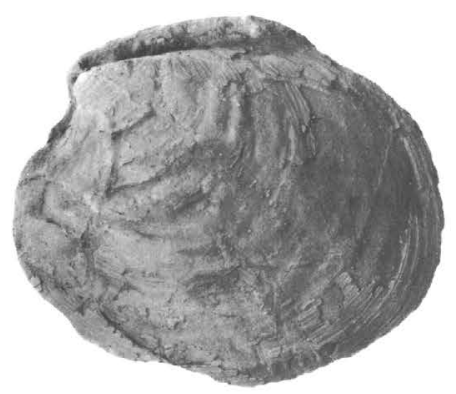

16
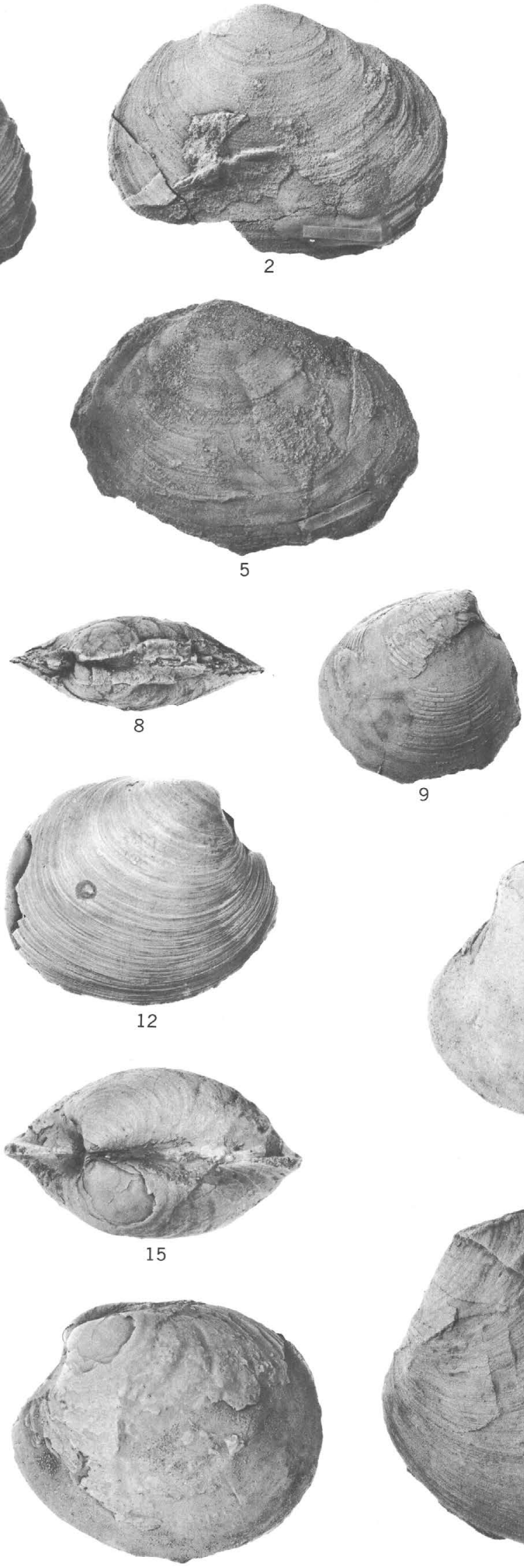

17
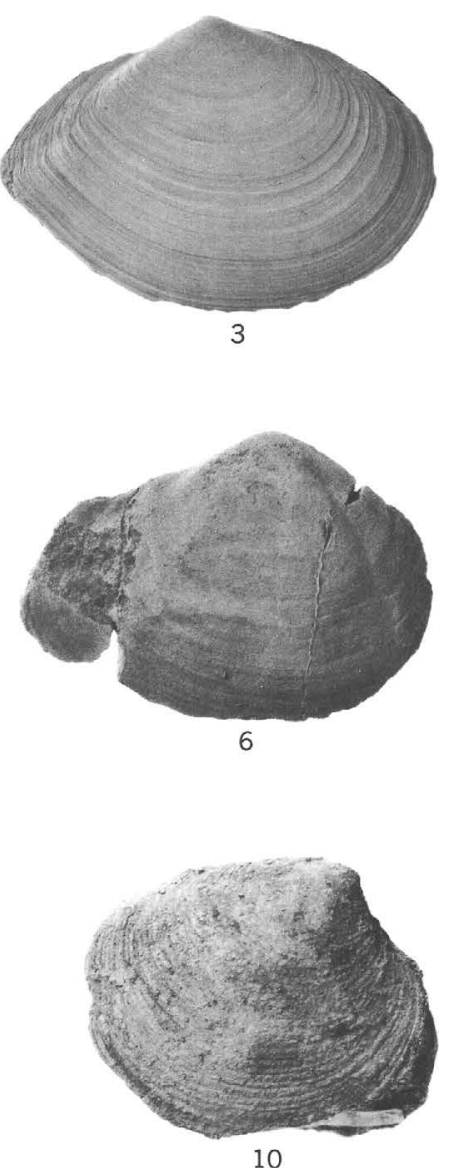

10

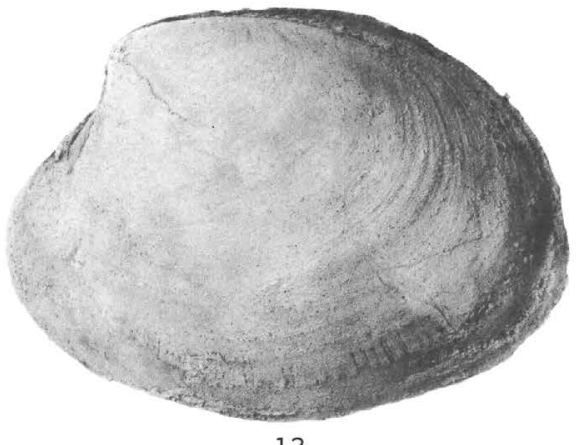

13

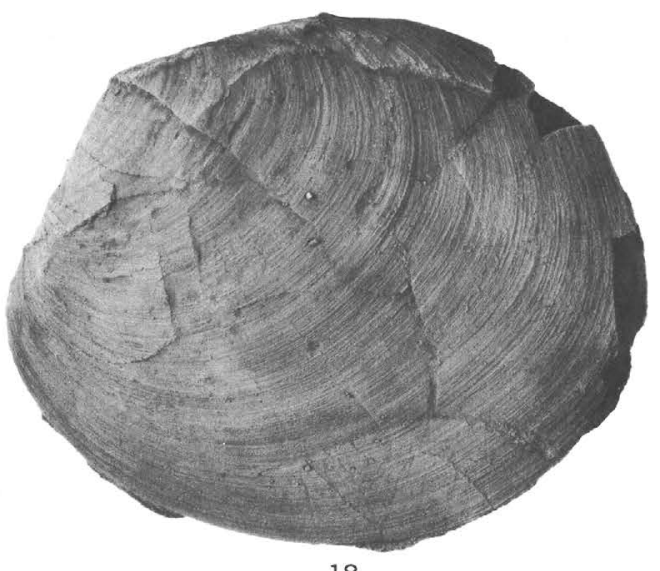

18 
PLATE 9

[All specimens are from the Clallam Formation]

Figures 1-3, 5, 6, 9, 10, 13. Securella ensifera (Dall).

1. Length $55 \mathrm{~mm}$, height $51 \mathrm{~mm}$. USNM 216064 . USGS loc. M4678.

2. Length $42 \mathrm{~mm}$, height $36 \mathrm{~mm}$. USNM 216065. USGS loc. M4683.

3. Holotype of Venus clallamensis Reagan (1909). Length 43 $\mathrm{mm}$, height $34 \mathrm{~mm}$. USNM 328312. Near Slip Point.

5. Length $49 \mathrm{~mm}$, height $47 \mathrm{~mm}$. SUPTC 10197. SU loc. NP89.

6. Length $49 \mathrm{~mm}$, height $40 \mathrm{~mm}$. SUPTC 10198. SU loc. NP89.

9. Length $39 \mathrm{~mm}$, height $39 \mathrm{~mm}$. USNM 216074. USGS loc. M4049.

10. Length $33 \mathrm{~mm}$, height $32 \mathrm{~mm}$. USNM 216066. USGS loc. M4051.

13. Holotype of Venus olympidea Reagan (1909). Length $35 \mathrm{~mm}$, height $31 \mathrm{~mm}$. USNM 328311

4, 12. Thracia trapezoides Conrad.

4. Length $59 \mathrm{~mm}$, height $45 \mathrm{~mm}$. SUPTC 10199. SU loc. NP163.

12. Length $34 \mathrm{~mm}$, height $30 \mathrm{~mm}$. USNM 216067. USGS loc. M4051.

7, 8, 16. Panopea abrupta (Conrad).

7. Length $53 \mathrm{~mm}$, height $37 \mathrm{~mm}$. USNM 216068. USGS loc. M4678.

8. Length $50 \mathrm{~mm}$, height $28 \mathrm{~mm}$. USNM 216069. USGS loc. M4683.

16. Length $78 \mathrm{~mm}$, height $42 \mathrm{~mm}$. USNM 216070. USGS loc. M4050.

11, 14. Thracia of. T schencki Tegland.

11. Length $35 \mathrm{~mm}$, height $23 \mathrm{~mm}$. USNM 216071. USGS loc. M4051.

14. Length $33 \mathrm{~mm}$, height $20 \mathrm{~mm}$. USNM 216072. USGS loc. M4051.

15. Panopea ramonensis (Clark).

Length $82 \mathrm{~mm}$, height $43 \mathrm{~mm}$. USNM 216073. USGS loc. M4678. 
GEOLOGICAL SURVEY
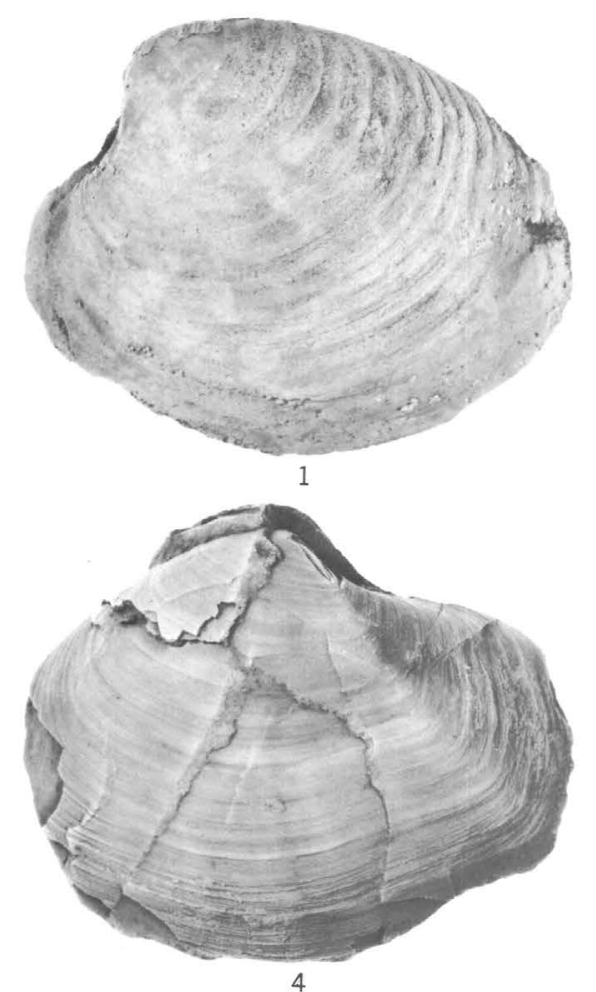

4

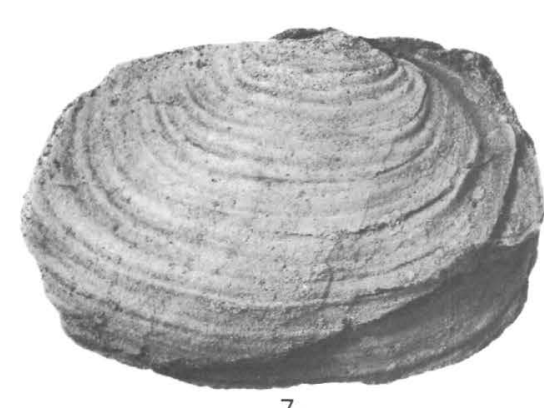

7
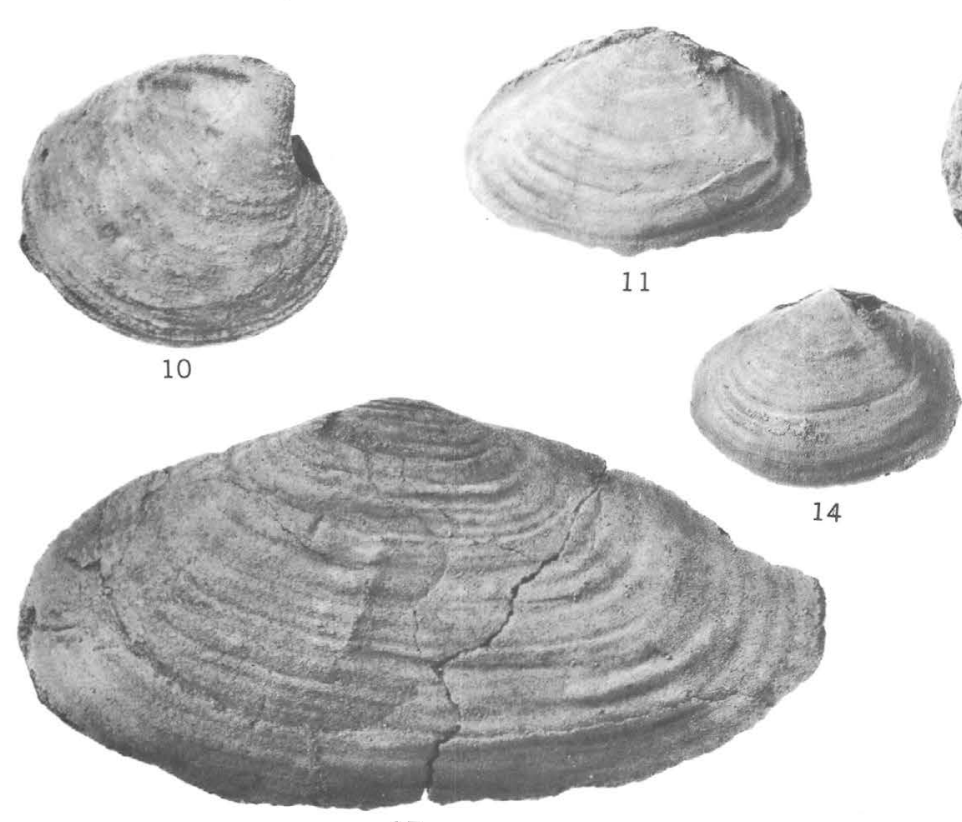

15

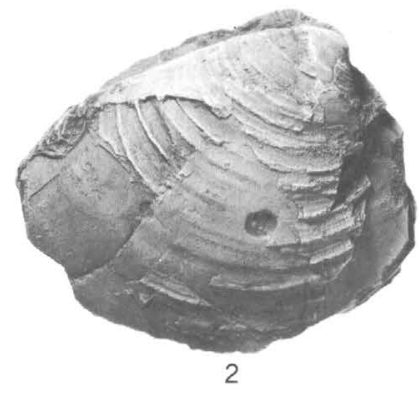

PROFESSIONAL PAPER 976 PLATE 9
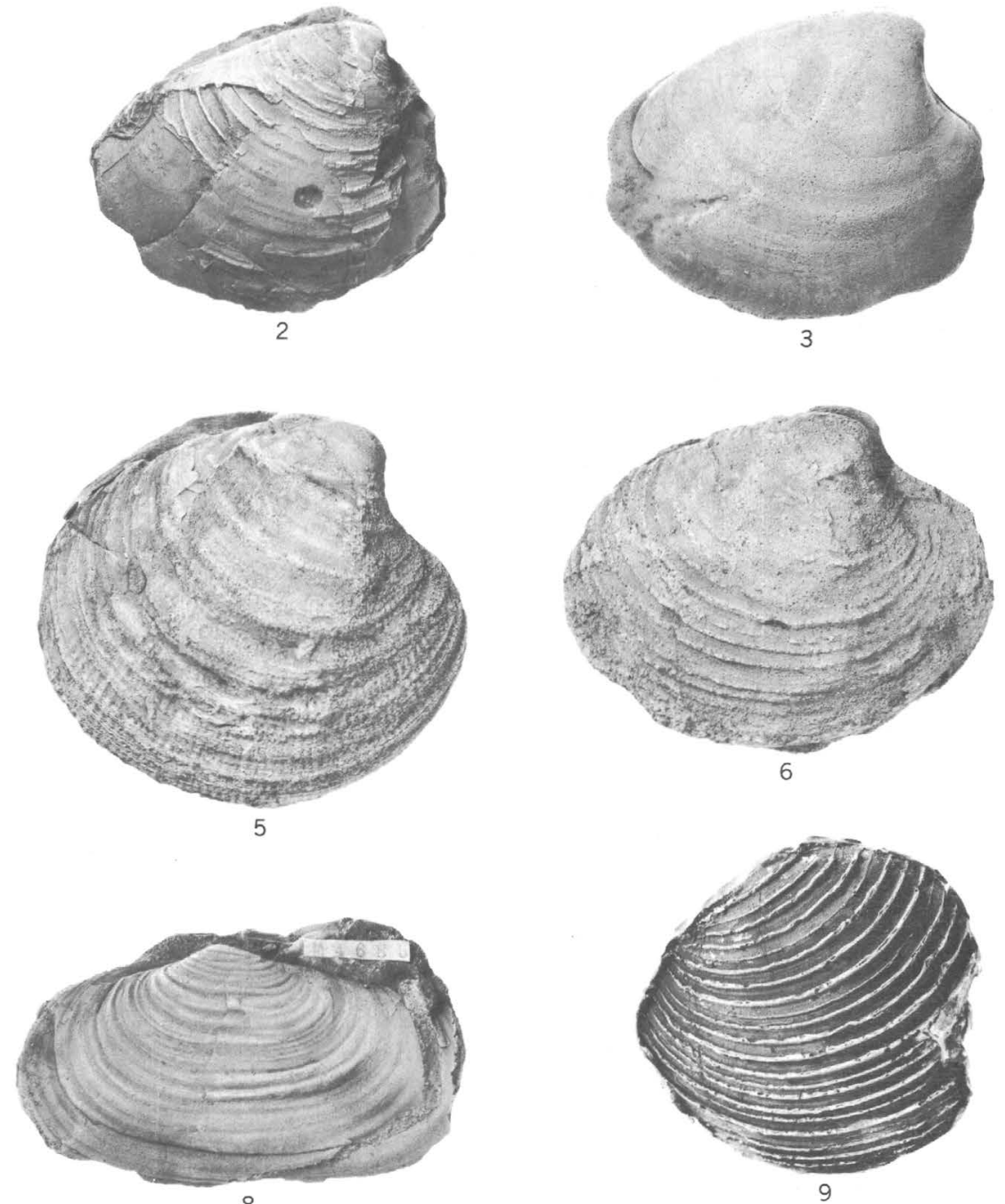

8

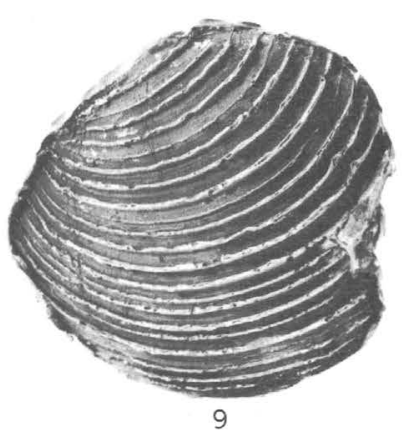

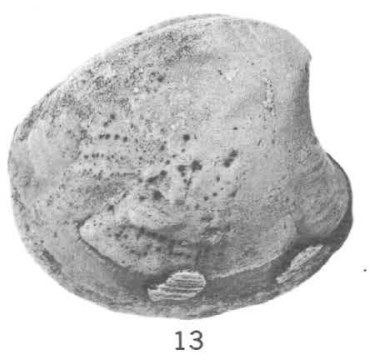

2

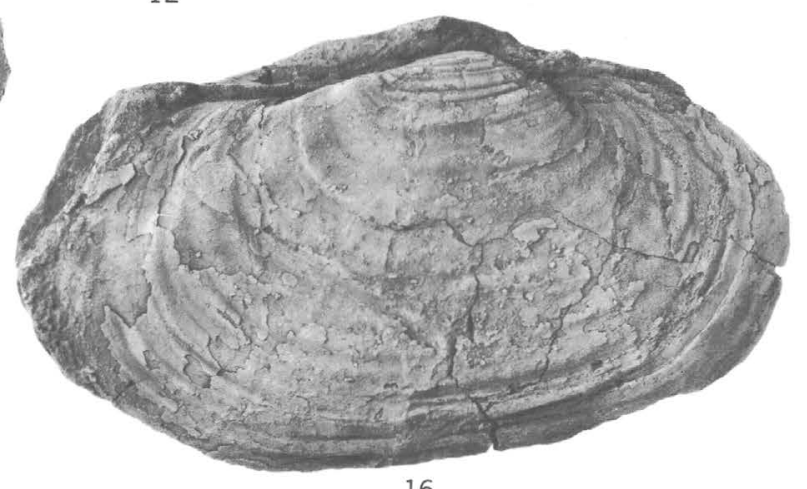

16

SECURELLA, THRACIA, PANOPEA 
